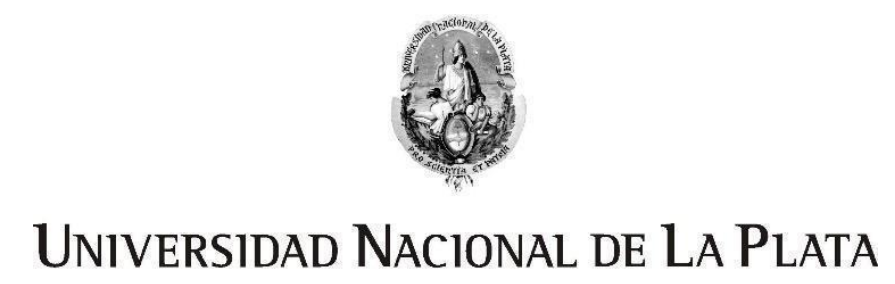

Facultad de Periodismo y Comunicación Social

MAESTRÍA EN COMUNICACIÓN Y EDUCACIÓN

COHORTE 2014

TRABAJO DE INTEGRACIÓN FINAL

\title{
EL AUDIOVISUAL COMO DISPOSITIVO DE INTERVENCIÓN
}

Una mirada al programa CineZap "Cine en las escuelas medias del sur de la ciudad de

Buenos Aires" desde la perspectiva de comunicación / educación

Análisis de dos experiencias: la Escuela de Educación Media No 6 Distrito Escolar 5 y la Escuela

Técnica Número 17 Brigadier General Don Cornelio de Saavedra.

Postulante:

Sandra Milena Sánchez

Directora:

Dra. Patricia Beatriz Vargas

Noviembre 2018 


\section{ÍNDICE}

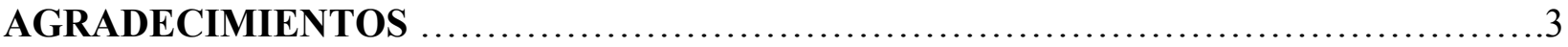

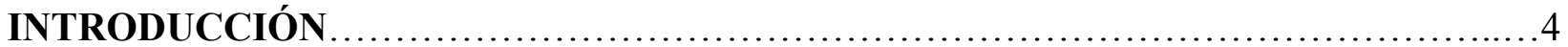

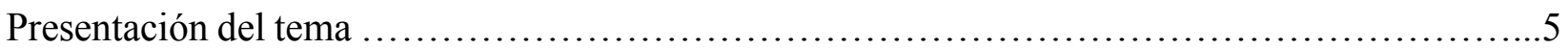

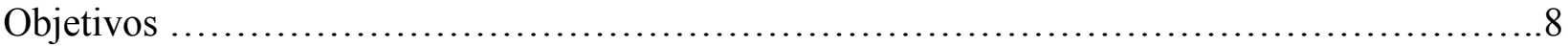

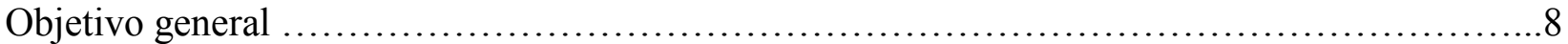

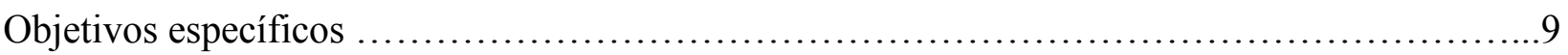

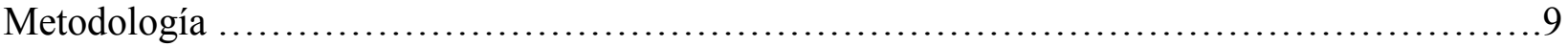

1. CAPÍtUlo 1: El programa CineZap, Cine en las Escuelas Medias del Sur de la Ciudad de Buenos Aires y su relación con el campo Comunicación / Educación ...................12 1.1. Escena 1 - Ext - día - Primeros momentos del programa

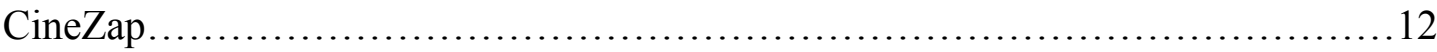

1.2. Escena 2 - Ext - día - Comunicación y educación, una mirada desde la práctica del programa CineZap .............................................................

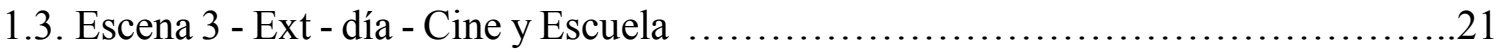

1.4. Escena 4 - Ext - día - Tiempos de CineZap, tiempos de la escuela .....................23

1.5. Escena 5 - Ext - día - El proceso de creación ....................................27

1.6. Escena 6 - Ext - día - Las temáticas: el lenguaje y la palabra ..........................35

1.7.Escena 7 - Ext - día - Los Cortometrajes ......................................38

1.8. Escena 8 - Ext - día - Los participantes, jóvenes y escuelas .........................50

2. CAPÍtUlo 2: La escuela técnica, una identidad tomada dentro del universo de la

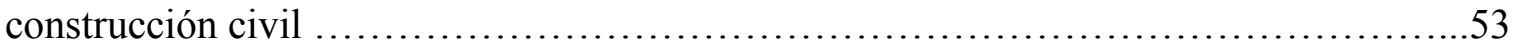

2.1. Escena 9 - Int - día - La escuela Técnica y los estudiantes de sexto año ................54

2.2. Escena 10 - Int - día - "Identidad robada”, del cuento al guión ........................56

2.3. Escena 11 - Int - día - Construcción de personajes - los estereotipos ...................60

2.4. Escena 12 - Int - día - Roles, cargos y apropiación ................................62 
2.5. Escena 13 - Int - día - Relación docente-alumno

2.6. Escena 14 - Int - día - La historia: el universo de la construcción civil y la identidad nacional

2.7. Escena 15 - Int - día - La grabación: materialización de las ideas, empoderamiento de los jóvenes

2.8. Escena 16- Int - día - Etapa de postproducción, la edición del cortometraje, cierre del proceso .80

2.9. Escena 17 - Int- día - Tensiones y transformaciones .84

3. CAPÍTUlO 3: Hacer cine en la escuela media, entretejiendo la realidad y la ficción .

3.1. Escena 18 - Int - día - La experiencia de hacer cine en la escuela media

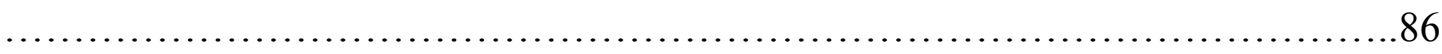

3.2. Escena 19- Int - día - De la literatura al audiovisual .............................93

3.3. Escena 20 - Int - día - Lazos: una historia de terror ...............................97

3.4. Escena 21 - Int - día - El cortometraje: qué se cuenta y cómo se cuenta ...............103

3.5. Escena 22 - Int - día - Reconstrucción de realidades ................................106

3.6. Escena 23- Int - día - La grabación, Día 1, tensiones de poder ........................108

3.7. Escena 24 - Int - día - La grabación, Día 2, autonomía y empoderamiento ............113

3.8. Escena 25 - Int - día - La edición, el cortometraje finalizado ......................116

3.9. Escena 26 - Int - día - El reconocimiento del mundo cultural y la resignificación de las fronteras

Conclusiones 120

Bibliografía

Anexos

.129 


\section{AGRADECIMIENTOS}

A Fernando Morabes, Lisandro Ursi, Cristian Gauna y Marcos Sachetti de CineZap

A los docentes y estudiantes de E.E.M. 6 D.E. 5 Polo Educativo Barracas y E.E.T. 17 D.E. 13

"Brig. Gral. Don Cornelio de Saavedra"

A Patricia Vargas, por su acompañamiento, predisposición y profesionalismo

A mis compañeros y docentes de la Maestría

A mis padres por su apoyo

A Camilo, por estar siempre ahí 


\section{INTRODUCCIÓN}

Esta tesis es elaborada dentro del marco de la Maestría en Comunicación y Educación, de la Universidad Nacional de la Plata, cursada entre los años 2014 y 2016. Tiene como objetivo dar cuenta de la investigación realizada acerca del programa "CineZap, Cine en las Escuelas medias del Sur de la Ciudad de Buenos Aires", en las actividades ejecutadas durante los años 2015 y 2016 en dos de las escuelas en las que trabajan.

Como eje central se analiza la propuesta metodológica de este programa, su vinculación directa con los medios de comunicación, en este caso el audiovisual y su implementación en espacios educativos, específicamente las escuelas. El programa CineZap busca vincularse a los currículos de las escuelas como un dispositivo, que posibilita la interacción entre los contenidos de diversas materias; a través del uso del lenguaje audiovisual, promueve un proceso de exploración y realización de cortometrajes por parte de los alumnos, cuya temática, análisis y reflexión esté vinculada a una propuesta curricular acordada previamente.

Este programa se enmarca territorialmente en escuelas medias del sur de la ciudad de Buenos Aires, lo que conlleva a intervenir y trabajar con comunidades escolares de características particulares, relevando la presencia de problemáticas como: la desescolarización, la violencia, el consumo y expendio de drogas, entre otras. Lo cual inevitablemente atraviesa la dinámica del programa y el cual pone su mirada en estas preocupaciones, si bien no para dar completa solución a ellas, si para ser un canal de visibilización, análisis y reflexión de las realidades que atraviesan a los distintos actores que intervienen en el proceso.

Desde las perspectivas que plantea el campo comunicación / educación, el programa CineZap, propone la implementación del audiovisual como un dispositivo de intervención, que atraviesa los ámbitos educativos, comunicacionales, sociales, familiares, institucionales y políticos de todos los actores que participan de esta iniciativa.

El desarrollo de esta investigación tiene tres momentos: en primera instancia analizo el contexto, los momentos fundantes, la metodología del programa CineZap y su relación con el campo 
comunicación / educación. Posteriormente hago un análisis de caso, de la experiencia de este programa en la escuela Técnica Número 17 Brigadier General Don Cornelio de Saavedra, que acompañé durante el año 2015. Y por último reconstruyo y reflexiono acerca de la intervención de CineZap en la Escuela de Educación Media N ${ }^{\circ} 6$ Distrito Escolar 5, actividad en la que participé durante el año 2016.

La propuesta de formato del presente texto, pretende emular la estructura y formas de escritura del audiovisual, nombrando los diferentes capítulos y sub-capítulos con el mismo formato del guión para cine y/o televisión, haciendo uso de la denominación "escenas" para referirme a cada subcapítulo. La escena es una unidad narrativa, usada en la dramaturgia para teatro, cine y televisión, que estipula el desarrollo de una o varias acciones en un espacio y tiempo determinado. La forma de estructurar la narrativa de este texto, no sólo permite hacer una división de los diferentes análisis que abordo, sino que a su vez, procura hacer una constante referencia al lenguaje audiovisual, uno de los ejes principales sobre los cuales se basa la propuesta metodológica de mi objeto de estudio: el programa CineZap.

\section{Presentación del tema}

El programa "Cinezap, Cine en las Escuelas medias del Sur de la Ciudad de Buenos Aires”, nace en 1998, vinculado al Ministerio de Educación de la Ciudad. Motivado por la idea de democratización de los bienes culturales y la inclusión de grupos y personas en situación de vulnerabilidad, con la finalidad de propiciar por medio del ejercicio de la producción audiovisual, la promoción del empoderamiento de los jóvenes como individuos y ciudadanos, con iniciativas de participación y capacidad crítica frente a la masividad de los medios de comunicación.

Para ello, planean y enfocan sus estrategias pedagógicas en las bases del reconocimiento del otro, el replanteo de las dinámicas internas de la escuela y un posicionamiento crítico del papel de la escuela en la sociedad y en la transformación de los sujetos, tal como ellos lo afirman: "Creemos que es imprescindible repensar y reorganizar por completo las lógicas dentro del aula, redefinir objetivos centrales, contenidos curriculares, estrategias didácticas, pero también, y sobre todo, refundar el vínculo docente-alumno.” (Escobar, Gauna, González y Morabes, 2012, p.2). Esta 
construcción se reconoce y dialoga con los planteos metodológicos, epistemológicos y políticos que propone el campo Comunicación y Educación; donde la postura de las intervenciones propias de este campo, implican un reconocimiento del mundo cultural de los sujetos con el fin de desnaturalizar prácticas hegemónicas (Huergo, 2007).

Con relación a la importancia e impacto que ha tenido este programa en las escuelas medias del sur de la ciudad de Buenos Aires, María del Rosario Luna, profesora de la Universidad de Buenos Aires, Doctora por la Universidad de Salamanca y ex-formadora docente del proyecto Cinezap, ha reflexionado acerca del aporte de este proyecto a la disminución de la desigualdad social y a la inserción social de los jóvenes a través de su desarrollo personal y comunitario; tema que trabaja en el capítulo que se titula "Producción de narrativas audiovisuales: inclusión y desarrollo comunitario en sectores sociales desfavorecidos de la ciudad de Buenos Aires" del libro Comunidad y comunicación. Prácticas comunicativas y medios comunitarios en Europa y América Latina.

El texto de Luna profundiza acerca de la práctica pedagógica del proyecto CineZap, el cual no sólo posibilita la crítica frente a los medios de comunicación, sino que, reubica a los alumnos en el lugar de protagonista de sus propias historias, les posibilita reflexionar sobre su cotidianidad y promueve la participación en comunidad, "analizando el trabajo en perspectiva, creemos que la riqueza de la experiencia, además de las dinámicas de intercambio y el sentido crítico que desarrollan los jóvenes en torno a los medios y a la comunicación, está en la posibilidad que brinda la producción audiovisual en objetivar pensamientos, intereses, deseos e inquietudes.” (Luna, 2012, p.209)

De igual manera, hace énfasis en la importancia de las temáticas, construcción de narrativas y personajes que se desarrollan en la práctica de CineZap, Luna hace referencia a la recurrencia de temas como el embarazo no deseado en adolescentes, el aborto, la violencia intrafamiliar, los conflictos de género, el consumo de drogas y la delincuencia, y la manera en que estos son abordados en las producciones audiovisuales desarrolladas en este proceso. La reproducción de narrativas audiovisuales, como las de géneros cinematográficos, también son usuales. Luna resalta el reiterado uso del género de terror, por ejemplo, como uno de los más usados en las producciones de CineZap del año 2011 o la reproducción de imaginarios colectivos en los cuales el o la 
protagonista de la historia es la o el más "lindo" del grupo, estereotipos reforzados por la televisión y por el cine; hecho ante el cual los alumnos se ven cuestionados y en algunos casos, discuten frente a este paradigma y logran crear nuevas alternativas, como por ejemplo reemplazar a la o el más "lindo" por el que mejor actúa o mejor se desempeña frente a la cámara.

Es así como al programa CineZap, podemos ubicarlo como una de las propuestas de exploración en comunicación y educación existentes en Latinoamérica. Situaciones, modelos y proyectos similares se replican a lo largo del continente, suscitando a su vez la necesidad de sistematizar, reflexionar y teorizar al respecto. Un acercamiento investigativo interesante lo hace Mauricio Romero Figueroa en su tesis para optar el título de Magister en Comunicación y Educación en la Universidad Distrital Francisco José de Caldas de Colombia; su trabajo titulado Sentidos de la comunicación escolar en entornos comunicativos contemporáneos. Estudio de Caso en el Gimnasio del Norte, retoma autores como Jorge Huergo, Paulo Freire, Mario Kaplún, Jesús Martín Barbero, entre otros, para remarcar la manera en que se puede hacer una lectura de la relación de los medios, en espacios educativos como la escuela, para reflexionar sobre el lugar del sujeto como actor, es decir, de los estudiantes como autores de sus propios relatos y de la mirada de los medios y la tecnología, no sólo como herramientas pedagógicas sino como dispositivos de transformación.

La investigación de Romero, se centra en un caso particular, la experiencia del colegio Gimnasio del Norte de la ciudad de Bogotá, Colombia, y la manera como sus estudiantes se apropian de las herramientas y del lenguaje para narrar sus propias historias. Usan la radio, el audiovisual y el periódico mural para hacerse autores de sus discursos, generar y compartir opiniones y reflexiones, enfatizando en el papel de la escuela como la posibilitadora de estas iniciativas. Evidencia cómo docentes y directivos se muestran abiertos y optimistas a las ideas de los niños y jóvenes que se empoderan de los medios de comunicación. Romero concluye el análisis de su experiencia, con señalamientos acerca de la importancia de comprender los medios y la tecnología dentro de los ámbitos escolares, como un lugar desde el cual construir con el otro, replantear el vínculo alumno - docente y promover espacios de apertura y encuentro para el aprendizaje.

Reflexiones e investigaciones como las de Romero aportan y nutren la construcción del campo comunicación/educación. Es por ello la responsabilidad que tenemos quienes nos identificamos 
con este campo, de aportar con nuestras perspectivas, rescatando la diversidad propia de cada experiencia estudiada o abordada, tratando de relevar desde diferentes miradas la complejidad e importancia del campo comunicación/educación y su horizonte político de transformación.

De esta manera el interés de esta investigación es contrastar y analizar las perspectivas de acción, las estrategias comunicacionales y educativas, y la proyección política del programa CineZap, con relación a la manera en que esto se adapta, se modifica, entra en conflicto y/o dialoga con las dinámicas institucionales de la Escuela de Educación Media N 6 Distrito Escolar 5, y la escuela Técnica Número 17 Brigadier General Don Cornelio de Saavedra. Relevando aspectos como: los tiempos institucionales, las dinámicas dentro del aula, las relaciones alumno-docente y la relación medios de comunicación y escuela, en diálogo con las reflexiones de autores como Jorge Huergo, Paulo Freire, Jesús Martín Barbero, Guillermina Tiramonti, María Beatriz Greco, Silvia Duschatzky, entre otros autores y perspectivas propias del campo comunicación/educación.

\section{Objetivos}

\section{Objetivo general:}

Analizar desde la perspectiva del campo Comunicación/Educación los contrastes entre los planteamientos pedagógicos y comunicacionales que propone el programa CineZap, y las dinámicas institucionales de las escuelas. Haciendo énfasis en: la concepción del espacio aúlico, las relaciones entre docentes y alumnos, los tiempos educativos e institucionales y las prácticas de comunicación/educación, en los casos de la Escuela de Educación Media No 6 Distrito Escolar 5 y la escuela Técnica Número 17 Brigadier General Don Cornelio de Saavedra.

\section{Objetivos específicos:}

- Identificar los momentos fundantes y transformaciones del programa "CineZap, Cine en las en las escuelas medias del sur de la ciudad de Buenos Aires” y específicamente las experiencias previas de su intervención en estas dos escuelas. 
- Relevar las discusiones que desde el campo Comunicación/Educación, proponen una relación dialógica y articulada del lenguaje y los medios audiovisuales, en los procesos de formación; entendidos desde una perspectiva no de herramienta pedagógica sino de dispositivo de construcción de sentido.

- Indagar acerca de los contrastes entre los planteamientos pedagógicos y comunicacionales que propone el programa CineZap, y las dinámicas institucionales de estas escuelas, con relación a la concepción del espacio aúlico, de las relaciones entre docentes y alumnos, los tiempos institucionales y las prácticas de comunicación/educación.

\section{Metodología}

Durante el 2015 y 2016 participé de las actividades del programa CineZap, en dos de las escuelas de la zona sur de la ciudad de Buenos Aires, en las cuales interviene este proyecto. En la escuela Técnica Número 17 Brigadier General Don Cornelio de Saavedra, ubicada en el barrio de Parque Avellaneda; acompañé el proceso entre los meses de mayo y noviembre del año 2015, con el grupo de 1er año, turno tarde. Y en la Escuela de Educación Media $N^{\circ} 6$ Distrito Escolar 5, ubicada en el barrio Barracas, entre los meses de abril y noviembre del año 2016 con el grupo de cuarto año, turno tarde.

Para el desarrollo de esta investigación, elegí el enfoque etnográfico. Rosana Guber, resume este método de la siguiente manera: "Una etnografía presenta la interpretación problematizada del autor acerca de algún aspecto de la realidad de la acción humana" (Guber, 2001, p.6). Partiendo de esto, reflexioné acerca de la manera en que éste programa adapta, modifica y/o pone en diálogo su metodología, posiciones políticas, pedagógicas y comunicacionales, frente a las dinámicas institucionales de cada escuela.

Relevé las percepciones y opiniones de quienes participaron: docentes, alumnos, coordinadores y practicantes; para reconstruir, a partir de sus actores, la experiencia vivida en cada uno de estos procesos. De allí la importancia de usar este método, ya que, como afirma Guber: "Como enfoque la etnografía es una concepción y práctica de conocimiento que busca comprender los fenómenos 
sociales desde la perspectiva de sus miembros (entendidos como "actores", "agentes" o "sujetos sociales") (Guber, 2001, p.12).

Para dar cuenta del contexto y comprender la estructura del programa CineZap, reconstruí las entrevistas realizadas a sus coordinadores; y además, propuse reflexiones acerca de las temáticas abordadas en los productos audiovisuales realizados en años anteriores, en estas dos escuelas.

En el acompañamiento a estas instituciones, participé de las diferentes actividades desarrolladas por el docente de CineZap y las docentes de las áreas vinculadas al programa, que en estos casos fueron de las materias de literatura y filosofía, durante la exploración y realización del cortometraje de ficción con el cual culmina el proceso anual de cada grupo. Las técnicas que utilicé fueron: la observación participante, la entrevista individual y la entrevista grupal. De esta manera pude dar cuenta de las relaciones, percepciones e ideas que los diferentes actores construyen con respecto a mi tema de investigación.

La observación participante, entendida como una estrategia que: "consiste en presenciar de manera directa el fenómeno estudiado en su "ambiente natural", sin manipularlo. La "observación participante" conlleva el involucramiento del investigador en una variedad de actividades, y por un periodo prolongado de tiempo, con el fin de observar a los miembros de una cultura en su vida cotidiana y participar en sus actividades facilitando una mejor comprensión de los mismos". (Marradi, Archenti y Piovani, 2007, p.191). A partir de esta técnica, pude identificar las discusiones y reflexiones que se dieron en las diferentes etapas del desarrollo de este proceso; tratando de dar cuenta de la complejidad de las percepciones de los diferentes actores que intervienen y la manera en que se relacionan con mi tema de investigación, retomando a Guber: "el objetivo de la observación participante ha sido detectar las situaciones en que se expresan y generan los universos culturales y sociales en su compleja articulación y variedad.” (Guber, 2001, p.56)

También usé la entrevista individual, comprendiéndola desde su complejidad performativa, como lo afirma Piovani: "en las ciencias sociales la entrevista se refiere a una forma especial de encuentro: una conversación en la que se recurre con el fin de recolectar determinado tipo de informaciones en el marco de una investigación" (Marradi, Archenti y Piovani, 2007, p.215). 
Resaltando que esta forma especial de encuentro no sólo pretende dar cuenta de la información textual que da el entrevistado, sino, analiza todos los aspectos que intervienen en la interacción que se da entre el entrevistado y el investigador; "desde una perspectiva constructivista, la entrevista es una relación social de manera que los datos que provee el entrevistado son la realidad que éste construye con el entrevistado en el encuentro.” (Guber, 2001, p.77)

Y con relación a la entrevista grupal, definida como una técnica que consiste en reunir a un grupo de personas para discutir sobre determinado tema, "a diferencia de la entrevista individual, dirigida al estudio de actitudes y opiniones de cada persona entrevistada, el grupo focal se orienta hacia una pluralidad de perspectivas vinculadas a una temática, que surge en la interacción colectiva, en cuya dinámica se ponen al descubierto las motivaciones y cosmovisiones de los participantes así como los usos frecuentes del lenguaje." (Marradi, Archenti y Piovani, 2007, p.227). A partir de este recurso, relevé las discusiones y reflexiones que se generan entorno a la visión colectiva que los jóvenes que participan de estas actividades, tienen acerca de los diferentes momentos y situaciones generadas durante este proceso.

Adicionalmente, elaboré un video con entrevistas de los participantes e imágenes sobre el proceso de creación de los cortometrajes en estas dos escuelas; el cual pretende dar cuenta de las opiniones y reflexiones que tuvieron los estudiantes durante las diferentes etapas. Este se anexa en formato digital a esta tesis. 


\section{CAPÍTULO 1: El programa CineZap, Cine en las Escuelas Medias del Sur de la Ciudad de Buenos Aires y su relación con el campo Comunicación / Educación}

En este primer capítulo expongo una descripción, rastreo y contextualización del programa "CineZap, Cine en las escuelas Medias del sur de la Ciudad de Buenos Aires", haciendo énfasis en su relación con el campo comunicación/educación y relevando sus hitos fundantes, el contexto político-social en el que se desarrolla y los actores que intervienen.

Recreo y analizo las conversaciones, entrevistas y observaciones de mi primer acercamiento al programa CineZap, particularmente con sus coordinadores. Relevo textos y producciones ya existentes acerca de la propuesta metodológica de mi objeto de estudio y propongo relaciones teóricas referentes al campo comunicación/educación.

\subsection{Escena 1- Ext - día - Primeros momentos del programa CineZap}

En el proceso de cursada de la maestría en Comunicación y Educación, entre los años 2014 y 2016, definiendo el tema de mi tesis, algunos compañeros y profesores me comentaron sobre la existencia del programa CineZap, de esta manera conseguí el número de teléfono de uno de los coordinadores: Marcos Sacchetti. Tras contactarlo telefónicamente nos citamos en un café ubicado en el barrio de Palermo para que me contara un poco más acerca del programa.

El encuentro fue un día viernes del mes de septiembre de 2015. Al llegar al lugar, Marcos estaba en una mesa al lado de la ventana que daba a la calle, no lo conocía personalmente pero lo reconocí por la imagen que había visto de él en la página web oficial de Cinezap, es un hombre de pasados los cuarenta años, de tez blanca y poco cabello. Entré al café y lo saludé presentandome. Pedimo unos cafés y le comenté mi interés de basar mi tesis de maestría en las experiencias de CineZap. Después de esto, él empezó a hablar sobre el programa, sin que yo le hiciera ninguna pregunta, asumí que estaba acostumbrado a que le pregunten sobre el proyecto y a hablar al respecto. Marcos comienza a narrar: 
"El proyecto "CineZap, Cine en las Escuelas del Sur de la Ciudad", nace en 1998 en la ciudad de Buenos Aires, promovido por el Ministerio de Educación de la Ciudad, el contexto político y social en el cual se gesta este programa, se caracteriza por la marcada disgregación social que existía en la ciudad, en algunos sectores y barrios, más marcadamente en la zona sur. El nivel de necesidades básicas insatisfechas era significativo y la escuela pública viene a jugar un papel relevante, en tanto no sólo se ocupaba de la alfabetización de niños y jóvenes, sino que, a su vez asistía a cuestiones que le desbordaban, como los niveles de pobreza, de violencia, de desempleo, entre otros."

Su tono era serio y su relato bastante fluido, como si hubiese contado esta historia cientos de veces. Después de un rato de contarme acerca de cómo este programa se empieza a gestar dentro de las políticas del Ministerio del Gobierno de la Ciudad, traté de indagar acerca de su papel en este proyecto y le pedí que me contara un poco más acerca de él y su experiencia en la etapa fundacional de Cinezap. Me comentó que inicialmente él trabajaba en el Ministerio de Educación de la Ciudad, y que, si bien esta preocupación de atender de alguna manera las zonas más desatendidas era una petición política del Ministerio, él y algunos de sus compañeros ya eran conscientes de estas problemáticas, así que emprendieron un programa que viene a ser el antecesor de CineZap. El programa al que hacía referencia se llama ZAP (Zonas de Acción Prioritaria), que tomó como base una experiencia francesa que lleva como nombre ZEP (Zonas de Educación Prioritarias) y de igual manera buscaba atender a las necesidades varias de escuelas en sectores desfavorecidos y con marcadas problemáticas sociales.

Marcos, continuó su narración afirmando que, se tomó este modelo y se buscó su adaptación al contexto de la Ciudad de Buenos Aires, pensado inicialmente para que no sólo abarcara el ámbito educativo, sino que impactara en otras áreas de gobierno como salud, infraestructura, planificación, entre otras, con el fin de dar soluciones íntegras a las necesidades de cada sector. 
Según Marcos, como suele suceder con la mayoría de los programas del estado, se sufren cambios o modificaciones durante su ejecución, y el caso del programa ZAP también estuvo sujeto a varias reestructuraciones. Se dan cuenta de que no podían abarcar todas las áreas de acción que se habían proyectado, así que deciden focalizar sus acciones únicamente en el área de educación.

Marcos no profundiza mucho acerca de su trabajo o de sus antecedentes profesionales; cuando le pregunté acerca de su trabajo en el Ministerio, me comentó brevemente que él ingresó a trabajar allí debido a su título de comunicador social, en un ámbito de trabajo multidisciplinar. Retomó el recuento del programa "ZAP" y comentó que, desde la coordinación del programa, se empiezaron labores de diagnóstico y planificación en los diferentes sectores de la zona sur de la ciudad, trabajando de manera conjunta no sólo con las escuelas, sino involucrando actores y organizaciones sociales interesados en promover alternativas a las problemáticas emergentes; Marcos afirma:

"Se tejió una red muy grande de relaciones con organizaciones civiles, con organizaciones de los barrios, la verdad que fue un laburo muy intensivo, y se trabajaba mucho con los directores de las escuelas, los supervisores. La verdad no era una política educativa dirigida desde el Ministerio, sino que de alguna manera se planteaba en reuniones barriales donde participaban directores, supervisores, docentes, miembros de la comunidad. Se planteaban cuáles eran las problemáticas del barrio, las problemáticas de los jóvenes, las problemáticas de la niñez, y a partir de ahí se hacía un gran diagnóstico y de ahí salían los proyectos para intervenir"

Durante la conversación, Marcos recalcó que, dentro del marco del programa ZAP (Zonas de Acción Prioritaria), lo que buscaban era atender a esas necesidades mencionadas anteriormente, y la manera en que este programa lo hace, es generando en una primera etapa, instancias relacionadas al ámbito de la comunicación, para promover espacios de discusión y análisis de las preocupaciones de cada comunidad. De esta manera se creó un programa de radio, se planificaron proyecciones cinematográficas para los alumnos de las escuelas y se hicieron capacitaciones a docentes relacionadas con la radio y el cine, para que ellos pudieran implementar diferentes estrategias 
dentro del aula, y acciones que posibilitaran estas instancias de transformación. Pero la razón por la cual se eligieron estos dos lenguajes en particular, tiene un disparador que nació de una anécdota en particular, así la recuerda Marcos:

"Una vez vienen unos directores y nos dicen: nosotros tenemos un gran problema con los pibes, con los chicos adolescentes que están por egresar y van a una reunión para pedir trabajo y los rebotan porque hablan de otra forma, no tienen la formalidad para presentarse a una entrevista de trabajo. Entonces dijeron: ¿de qué manera podemos trabajar distintas situaciones de oralidad, de escritura, que planteen instancias comunicativas de los pibes? Así es como nacen los dos proyectos, el de cine y el de radio. Cómo brindarles situaciones distintas a los chicos para que puedan pensar otras situaciones de comunicación distintas a las que tienen cotidianamente."

De la elección de trabajar con estos dos lenguajes: la radio y el cine, la propuesta ZAP se dividió en dos programas: REC, que va a abordar todo lo relacionado con la radio y CineZap que se va a enfocar en el lenguaje cinematográfico.

De esta anécdota en particular, el ya conformado programa CineZap, enfocó sus capacitaciones a docentes en el área de escritura de guiones de ficción para cortometrajes, con el fin de que allí los jóvenes pudieran plasmar sus preocupaciones, ideas y todo aquello que los atravesaba. Tras un año de trabajar en la escritura de guiones, los docentes de las escuelas les hicieron la devolución a los coordinadores del programa, expresándoles el deseo de los jóvenes por materializar sus guiones, es decir, deseaban grabar y editar las historias que habían construido. Según Marcos, esta petición representaba un gran reto para el proyecto, puesto que esto implicaba un despliegue logístico, técnico y organizacional que no se había contemplado hasta el momento.

Casualmente, comenta Marcos, para el 2001 la Fundación Universidad del Cine (FUC) lanzó un profesorado en Comunicación Visual con orientación en Procesos Educativos y se encuentraban en la búsqueda de espacios, en los cuales sus estudiantes pudieran realizar sus prácticas docentes y allí es cuando se generó la vinculación con esta organización, así lo relata Marcos: 
"Después, de casualidad, la FUC (Fundación Universidad del Cine) estaba lanzando un profesorado, ellos necesitaban escuelas para que sus alumnos pudieran hacer sus prácticas y nosotros necesitábamos equipamiento, lugar para editar, lugar para hacer la muestra. Entonces en el 2001 nace formalmente esta forma de práctica, con alumnos voluntarios de la Universidad del Cine, específicamente con una materia que era: "didáctica". Empezamos a ir a las escuelas y a frentear lo que fue el inicio del proyecto; empezamos a juntarnos a trabajar en un aula con una cantidad de alumnos, que eran los que la escuela nos proponía, y ahí salió el primer corto, y a partir de ese año empezamos a diagramar un sistema de producción distinto; hasta ese momento veníamos trabajando sobre capacitaciones para docentes y a partir de ahí empezamos a trabajar directamente con docentes y con los alumnos de las escuelas."

De estas anécdotas en particular, el programa CineZap afrontó el gran reto de modificar, reconstruir y proponer un nuevo esquema de trabajo, que ahora involucraba directamente a los estudiantes de las escuelas, y más profundamente entrar a intervenir en el aula, hacer parte de las actividades y de las normativas de las instituciones educativas.

\subsection{Escena 2 - Ext - día - Comunicación y educación, una mirada desde la práctica del programa CineZap}

Después de contactar a Marcos Sacchetti, él me facilitó el número de teléfono del otro coordinador de CineZap: Cristian Gauna. Tras contactarlo telefónicamente y pedirle una entrevista, nos citamos en un café del barrio Boedo. El día acordado, un día soleado del mes de abril de 2016, me reuní con Cristian, un hombre acuerpado, de cuarenta años aproximadamente. Me saludó efusivamente y me invitó un café. Tras comentarle un poco de mi experiencia y de mi intención de tesis, le conté que ya me he reunido con Marcos, pero ahora quería que él me contara desde su experiencia, cómo se había creado CineZap. 
Le pregunté un poco acerca de sus antecedentes profesionales y de cómo llegó a involucrarse en CineZap. Me contó que él también es comunicador social, al igual que Marcos, y se conocen de trabajos en común. Comentó que cuando se creó la división de ZAP y se constituyó formalmente el programa CineZap, Marcos y él fueron llamados a coordinar el programa.

Cristian comentó brevemente algo muy similar a lo que Marcos me había contado sobre los antecedentes del programa ZAP, la posterior creación de CineZap y su énfasis en educación sobre el lenguaje audiovisual dentro de las escuelas medias del sur de la ciudad.

Cuando el programa CineZap comenzó a intervenir directamente en las aulas y a trabajar conjuntamente con estudiantes y docentes dentro de las escuelas, se plantaron una serie de retos y de discusiones en torno al papel del audiovisual como herramienta pedagógica y al papel de los medios de comunicación no sólo dentro del aula sino a una mirada crítica de las formas de producción y de consumo.

Según Cristian, las grandes inquietudes por parte de coordinadores, docentes del programa CineZap, directivas y docentes de las escuelas vinculadas al programa, giraban en torno al concepto de individuos y de ciudadanos que se estaban formando, de cómo la mirada mercantil del momento ponía a las personas en condición de consumidores pasivos y nunca en el papel de protagonistas y productores de sus propios discursos. Teniendo conciencia de esto y de la responsabilidad de la escuela, en la promoción de miradas críticas ante las diversas realidades, se plantearon como reto, generar instancias de reflexión acerca de las dinámicas del consumo de los medios de comunicación, Cristian afirma:

"El Estado debe intervenir y generar políticas públicas para que los ciudadanos tengan garantizados sus derechos no sólo como consumidores, sino también como sujetos de derechos, como niñas, niños y adolescentes, con sus derechos de acceso y participación activa en la comunicación masiva... derecho a la información, a publicar libremente 
sus ideas, etc... la escuela, es el espacio natural para educar, y modificar esta situación."

Para Cristian, las discusiones latentes de principios de los años 2000 acerca de las formas de consumo, no eran la única preocupación al momento de intervenir con el programa CineZap en las escuelas, estaba también la resistencia de la inclusión de nuevas tecnologías en el aula y el gran reto era: ¿cómo generar instancias en las cuales, a partir del audiovisual no sólo como herramienta, sino visto como un dispositivo de intervención, se podían generar espacios de reflexión, visibilización y transformación de las realidades de los estudiantes y de las comunidades que participaban del programa?

Tras una indagación bibliográfica que realicé posterior a estas entrevistas, y material facilitado por Cristian y Marcos, encontré una ponencia de Cristian escrita para para la I Bienal Latinoamericana de Infancias y Juventudes, realizada en Colombia, en noviembre de 2014. Lleva como título: Mediación del cine y su lenguaje como un dispositivo y expone claramente esta idea anterior:

"Desde el momento de la fundación del Programa Cine en escuelas del Sur de la Ciudad y el Proyecto CINEzap, allí por los años 1998 a 2000, está claro que no se pensó en estos lineamientos académicos. Pero ya desde aquel hacer e intervenir en las escuelas, se pretendía denunciar un funcionamiento de la industria que intuíamos, pero aún no resultaba tan evidente. Por otra parte, encontrábamos que superar la mirada desconfiada sobre los instrumentos tecnológicos y los medios audiovisuales podía aportar mucho en el trabajo cotidiano con poblaciones que presentaban altos niveles de NBI (Necesidades Básicas Insatisfechas) y que el generar políticas educativas públicas en pos de mejorar la equidad en contextos en los que era imprescindible reconocer la desigual distribución de bienes (simbólicos y materiales)" (Gauna, 2014, p.3)

Esta preocupación manifestada por Cristian, es un tema que ya ha tenido algunas reflexiones en los contextos de educación, comunicación y cultura, específicamente en Latinoamérica. Jesús Martín 
Barbero, ha analizado esta problemática de la democratización de los bienes culturales y la inclusión de grupos y personas en situación de vulnerabilidad. Barbero promueve el empoderamiento de los jóvenes como individuos y ciudadanos con iniciativas de participación y capacidad crítica frente a la masividad de los medios de comunicación (Barbero, 1987).

Indagando un poco más acerca de los lineamientos políticos y educativos del programa CineZap, me encuentré con otra ponencia realizada por Cristian en conjunto con: Andrés Escobar, Lisandro Ursi y Fernando Morabes, docentes de Cinezap. Lleva por título: Hacer Cine, un dispositivo de intervención socioeducativa, escrita para el Congreso de Periodismo y medios de comunicación de la Facultad de Comunicación Social y Periodismo de la Universidad Nacional de La Plata, en mayo de 2012 .

Allí hablan sobre la experiencia de CineZap en las escuelas medias del sur de la ciudad, y de la manera en que ellos planean y enfocan sus estrategias pedagógicas en las bases del reconocimiento del otro, el replanteo de las dinámicas internas de la escuela y un posicionamiento crítico del papel de la escuela en la sociedad y en la transformación de los sujetos.

"Creemos que es imprescindible repensar y reorganizar por completo las lógicas dentro del aula, redefinir objetivos centrales, contenidos curriculares, estrategias didácticas, pero también, y sobre todo, refundar el vínculo docente-alumno.” (Escobar, Gauna, González y Morabes, 2012, p.2).

Esta construcción se reconoce y dialoga con los planteos pedagógicos y políticos que propone el campo Comunicación/Educación, como lo afirma Jorge Huergo:

"Desde la postura de este equipo de trabajo, intervenir a partir del campo de comunicación/educación implica un reconocimiento del mundo cultural de los sujetos 
(en términos de Paulo Freire el universo vocabular) para desnaturalizar prácticas hegemónicas. En este punto es necesario tener en cuenta que las acciones tendrán que ser conscientes y deliberadas, para intentar desarreglar un orden y orientarlas a partir de la voluntad de transformación.” (Huergo, 2007, p.5)

En esta idea del reconocimiento del otro, del trabajo y la reflexión con el otro, se plantean las estrategias de trabajo de CineZap en las escuelas. La invitación a la creación colectiva de un cortometraje de ficción, lleva a sus participantes a transformar conceptos, teorías e ideas abstractas en imágenes y sonidos que transmiten un mensaje, una historia que les identifica y de la cual ellos son autores. De este pensar, reflexionar y hacer, se entiende el concepto de Praxis (Freire, 1970) aplicado a las actividades escolares del programa y materializado en piezas audiovisuales, de esta manera es como se concibe el trabajo reflexivo del programa; con respecto a este concepto de praxis Cristian afirma:

"En la praxis, las ideas se prueban y experimentan en el mundo real. Y luego se ponen en tensión reflexiva. De esta manera los conceptos estudiados teóricamente se relacionan y conectan vitalmente con la realidad. Por lo tanto praxis es la acción en relación reflexiva con sus efectos en la realidad y en relación con los emergentes desarrollados por el sujeto participante a nivel cognitivo, actitudinal y procedimental. CineZap es un dispositivo fundado en la praxis, y por lo tanto pretende organizar un espacio de aprendizaje experimental y así establecer una práctica profesionalizante que motorice conscientemente las vinculaciones de las interacciones entre práctica vivida, con la teoría preexistente, para que genere conocimiento emergente enriquecido por la tensión entre lo enseñado y lo experimentado." (Gauna, 2014, p.8)

Estos dos conceptos, reconocimiento y praxis, van a ser los grandes puntos de encuentro entre la práctica del programa CineZap y las teorías y reflexiones del campo comunicación/educación, elementos que serán retomados y reforzados en posteriores señalamientos y ejemplos. 


\subsection{Escena 3 - Ext - día - Cine y Escuela}

La discusión de finales del siglo XX en Latinoamérica, entre medios de comunicación y escuela, sus variantes y corrientes de análisis, son el caldo de cultivo de muchas de las propuestas de comunicación que van a insertarse en el ámbito escolar, "el problema de la pedagogía de la comunicación es uno de los temas pioneros en cuanto a la reflexión latinoamericana de la relación Comunicación/Educación. Su abordaje fue inicialmente propuesto desde el ámbito pedagógico, debido a la preocupación que significó el desarrollo de la cultura mediática." (Huergo, 1997, p.16). Este debate parece latente entre quienes coordinaban y ejecutaban el programa CineZap. Interrogantes y preocupaciones acerca de la implementación del lenguaje audiovisual en el aula, lo pedagógico y el lenguaje de los medios masivos de comunicación, entre otros temas, fueron los que ayudaron a construir la dinámica y las estrategias que se vivencian en las actividades del programa, al respecto Cristian me comenta:

"Una de las discusiones era: ¿cómo hacer que los medios nos ayuden y no que compitan con el maestro? inicialmente lo que se hizo fue trabajar con los textos y a partir de eso capacitar a los docentes para que puedan ver qué contenidos ellos querían trabajar y que podían dar respuestas a estas necesidades insatisfechas de estas poblaciones."

Para Marcos, durante las primeras incursiones en la escritura y grabación de los cortometrajes de ficción, docentes de las escuelas y docentes del programa, resaltaban rasgos positivos, como la posibilidad de visibilizar y dialogar los intereses y preocupaciones de los jóvenes en las escuelas, elementos que son constantes en la práctica dentro del aula y en las piezas audiovisuales resultantes de este proceso, Marcos comenta:

"Cuando entramos a las escuelas nos encontramos con que en el proceso de escritura hay algo que pasa que es muy rico, que hay algo de lo que le atraviesa a los chicos que emerge en el aula, osea, salen las historias de las cosas que les está pasando, que a ellos les preocupa, de su vida cotidiana. Hay algo que tiene la ficción, nosotros siempre 
planteamos procesos de ficción, entonces la escritura de ficción es como que de alguna manera les da la posibilidad de convertirse en otro, y desde ese lugar de decir: me está pasando esto, estas son las cosas que me preocupan..."

Dentro de los debates académicos actuales, aún sigue vigente la discusión entre la relación comunicación-cine-escuela, pero lo que se puede observar es, que las preocupaciones no abarcan más el ámbito de tensión de la inclusión de los medios en el aula, sino que, al parecer, los docentes han superado esa brecha tecnológica y se han empoderado de los conocimientos de los medios masivos de comunicación para llevarlos al espacio áulico. Es por ello que quizá la discusión actual sobre esta relación de medios y escuela, gira hoy en torno al carácter pedagógico y a la manera de construir estrategias que vinculen la tecnología, el lenguaje de los medios y las prácticas curriculares.

Para el caso particular de la experiencia CineZap, pude observar en mis charlas con los docentes de cine y los docentes de las escuelas, que ellos concuerdan en que esta práctica, que propone una nueva configuración de las dinámicas educativas, promueve transformaciones que van desde el rol docente, la re-concepción material de los espacios como el aula, la interacción y protagonismo de los estudiantes, hasta la reformulación de la idea de los medios, específicamente el audiovisual, vistos solamente como una herramienta dentro del aula (Huergo, 1997, p.22), para pasar a pensarlo como un dispositivo mucho más amplio que propicie espacios para la exploración, la participación, el empoderamiento y el debate. Así lo afirma Cristian: "Por eso, dejamos de hablar de rupturas y hablamos de reconfiguración del espacio áulico, extensión del espacio áulico, la reconfiguración de las relaciones y de las interacciones, y tiene que ver más con eso, pensar en que lo que uno hace es generar nuevas reconfiguraciones y también empoderar a los docentes para que puedan tomar decisiones con cómo quieren enseñar" 


\title{
1.4. Escena 4 - Ext - día - Tiempos de CineZap, tiempos de la escuela
}

Conversando con Cristian me comentaba, que desde la creación de este programa, diversas dificultades y retos se han presentado a lo largo de estos 15 años, su naturaleza varía entre discusiones políticas, pedagógicas e institucionales, hasta dificultades logísticas y del carácter de las relaciones interpersonales. Pero para Cristian, quizá unos de los mayores retos que se presentó, al entretejer la práctica del programa, con los planes y tiempos de la escuela, tiene que ver con encontrar esos puntos en común y tratar de mediar con las dinámicas de cada institución, Cristian afirma:

\begin{abstract}
"Marcos (Marcos Sachetti, Coordinador del programa), empieza a trabajar en la forma en cómo se adecua algo que no es pedagógico para que entre dentro de los marcos, de los tiempos pedagógicos, de los tiempos institucionales. Porque eran tiempos pedagógicos en donde se invita al estudiante a que participe, pero los tiempos institucionales son diferentes"
\end{abstract}

Esto significa dialogar y generar espacios de acción, hacerle frente a los cambios que hoy por hoy la escuela, los docentes y otros actores que median estos espacios, están presenciando. Cambios en lo pedagógico, en la dinámica del aula, en la relación docente-alumno, en las formas de concebir el conocimiento. Temas que también se manifiestan en los diferentes autores y reflexiones que se producen dentro del ámbito académico y práctico de quienes se inscriben en el campo comunicación/educación.

También cabe nombrar que, según Cristian, las dificultades han transitado por el ámbito de lo burocrático y lo institucional. Para que los docentes de las escuelas puedan vincularse de lleno al programa, en muchas ocasiones se requiere de trabajo extracurricular, dedicar tiempo a las planeaciones, días de grabación y edición de los cortometrajes, actividades que no están contempladas dentro de las horas laborales y salariales de los docentes. Esto representa un hecho 
importante para la permanencia del programa y para el compromiso de los docentes, es por ello que desde la organización del programa han buscado formas, estrategias y alianzas que promuevan y reconozcan la labor y participación de los docentes de las escuelas, como lo menciona Cristian: "hace 4 años eso se complicó muchísimo, entonces buscamos otras formas de hacer las capacitaciones, aparecieron gremios...”, para Cristian, buscar financiación y validación de las horas extras para los docentes que participan de CineZap, sigue siendo una de las aristas conflictivas del proyecto.

Es así como docentes, capacitadores, coordinadores, directivos y demás actores que intervienen en la ejecución del programa CineZap, deben adaptarse a los cambios propios de los nuevos paradigmas de lo que significa hacer cine en las escuelas, identificando y reflexionando sobre los nuevos retos y proponiendo estrategias que se correspondan a las demandas y necesidades de la vinculación entre la realización audiovisual y la escuela.

Partiendo de estas premisas, la dinámica que propone el programa, es sumarse de manera continua al proceso anual de escolarización de los alumnos. Iniciando el año lectivo, coordinadores y capacitadores de CineZap se reúnen con directivos y docentes de las nueve escuelas, con las que han venido trabajando los últimos años. Se inician conversaciones y por lo general se llegan a acuerdos para incluir las actividades de CineZap en cada escuela. Excepto casos puntuales, en los que por algún motivo logístico o solicitudes específicas, una escuela no pueda sumarse algún año, suelen participar año tras año las mismas escuelas, éstas son:

- Comercial 6 D.E. 13 "América"

- E.E.M. 1 D.E. 13 "Manuel Mujica Láinez"

- E.E.M. 1 D.E. 20 "Biblioteca del Congreso de la Nación"

- E.E.M. 3 D.E. 19 "Carlos Geniso"

- E.E.M. 4 D.E. 21 "Norma Colombatto"

- E.E.M. 6 D.E. 21 Escuela de Reingreso

- E.E.M. 6 D.E. 5 Polo Educativo Barracas 
- E.E.T. 17 D.E. 13 "Brig. Gral. Don Cornelio de Saavedra"

- EEM 2 DE 19 "Arturo Jauretche"

Posteriormente, desde cada escuela se decide qué docentes desean vincular su materia a las actividades del programa (literatura, filosofía, historia, derecho, biología, etc), y luego se elige un grupo (grado) con el cual trabajar. A partir de ese momento, el capacitador de cine, los docentes y directivos de la escuela, planifican los temas y las actividades a realizar durante el año, haciendo énfasis en que realizarán la escritura, planificación, grabación, edición y muestra de un cortometraje de ficción por cada grupo en cada escuela. Dentro de las actividades del programa se contemplan visitas a la Universidad del Cine, donde realizan una actividad práctica, haciendo uso de los equipamientos técnicos de la institución y aplicando los conceptos de realización audiovisual que se han trabajado durante las clases. De esta manera, se construyen de manera conjunta, entre docentes, capacitadores y directivos, los lineamientos pedagógicos para trabajar durante las clases.

Alternadamente con las clases de cine en las escuelas, el programa CineZap realiza actividades de capacitación docente, para aquellos profesores interesados en vincular el lenguaje audiovisual a sus prácticas educativas, como lo comenta Cristian:

"Sobre la capacitación docente: significaba organizarse con el CePA (Centro de Capacitación Docente), y si bien la capacitación la daba CineZap, formábamos a los docentes que iban a participar en el proyecto CineZap, pero también formábamos a todo aquel docente que quiera aprender algo de cine y a utilizar el cine como un dispositivo pedagógico o que pueda también utilizarlo sólo como una herramienta pedagógica.... Y poder lograr que los docentes lo puedan usar como una herramienta... había docentes que no lo pensaban así... Bueno ¿qué hacemos con los docentes que quieren hacer cine en la escuela? ¿qué quieren enseñar haciendo cine? ¿cómo hacer que lo puedan hacer si no tienen CineZap?, que puedan hacerlo ellos con un dispositivo pequeño, luego algunos criterios, sobre cómo se filma, con lo que existe, el celular, las cámaras de conectar igualdad." 
El gran reto que implica no solamente implementar un dispositivo basado en la creación audiovisual, sino hacer que este dispositivo se vincule de manera armónica a las dinámicas de la escuela, es uno de los puntos a resaltar en esta reflexión. Los tiempos de las escuelas no siempre suelen corresponder con los tiempos que precisa el programa CineZap para la ejecución de sus actividades, esto implica que en algunos momentos las actividades planeadas rompan o no se correspondan con los tiempos escolares, por ejemplo, durante los días de grabación, generalmente los participantes deben asistir a los encuentros en horarios y lugares diferentes a los de sus clases habituales.

De esta manera se habla de una extensión del espacio y de los tiempos áulicos. Estas actividades se contemplan como parte del proceso de aprendizaje y experiencial, pero se desarrollan en lugares y tiempos diferentes a los que tradicionalmente manejan las instituciones educativas; "el planteo de generar un dispositivo de intervención escolar, supone por primera condición que estas prácticas serán de carácter escolar, aun cuando territorialmente se exceda y extralimite los espacios propios de la escuela. La institución, como sistema organizacional, se funda en los participantes y sus concepciones y trasfondo comunicacional que resultan en un tipo de límites fundantes. Que fundan la relación escolar, cooperativa, productiva, y sobre todo pedagógica.” (Gauna, 2014, P.9)

Esta relación de tiempos y de dinámicas escolares en las cuales interviene el programa CineZap suele generar espacios y propuestas que expanden la experiencia de aprendizaje, al expandir los límites físicos del aula, se genera otra idea de aprendizaje en los participantes, se les invita a reflexionar acerca de propuestas alternativas, en las cuales su participación activa les pone en el lugar de protagonistas y de autores, les motiva a empoderarse, a ser críticos y a tomar sus propias decisiones. 


\subsection{Escena 5 - Ext - día- El proceso de creación}

Después de confirmadas las escuelas con las cuales se trabajará, el equipo de CineZap, conformado por cinco docentes, los dos coordinadores y el personal administrativo como secretaria y encargada de las publicaciones web, se reúnen para definir cómo se van a realizar las actividades del año, analizan, por ejemplo, la elección de alguna temática transversal para trabajar en las escuelas. Cristian me comentaba que para ese año, 2016, se eligió trabajar en todas las escuelas el tema de géneros cinematográficos. Tras definir esto, entre todos los integrantes del equipo, discutieron algunos conceptos y autores con los cuales trabajar en el aula, aunque la decisión pedagógica y logística de cómo implementar estos conceptos con los estudiantes, es de completa autonomía de cada docente de cine. También tienen cabida reflexiones de carácter político, ligado a los cambios de gobierno y la manera en que esto interviene en sus prácticas a nivel logístico, económico y de postura política.

Se asignan los docentes de cine para cada escuela, en algunos casos un mismo docente puede tener a su cargo dos escuelas. Estos temas se analizan en una reunión al iniciar el año y después se programan un par de reuniones más para evaluar diferentes temas que vayan surgiendo durante el desarrollo de las clases.

Al empezar mi trabajo de campo directamente en las escuelas, elegí, por mi disponibilidad horaria, trabajar con dos escuelas: La escuela Técnica Número 17 Brigadier General Don Cornelio de Saavedra junto con el docente de cine Fernando Morabes; y la Escuela de Educación Media N 6 Distrito Escolar 5 con el docente de cine Lisandro Ursi. Durante mis primeros días acompañando el proceso de CineZap, me fui empapando de la dinámica de trabajo en cada escuela.

Cristian me explicaba que, particularmente, en estas dos escuelas, las clases de cine se han implementado con las mismas materias y docentes durante los últimos años, por ejemplo en la escuela Técnica Número 17 Brigadier General Don Cornelio de Saavedra, por tres años 
consecutivos las clases de cine se vincularon a la materia de Literatura con la misma docente. En el caso de la Escuela de Educación Media N ${ }^{\circ} 6$ Distrito Escolar 5, durante dos años consecutivos, con las mismas docentes se trabajó conjuntamente con las materias de filosofía y literatura.

Posteriormente a esto, se define con qué grupo (grado) realizar las clases de cine, cuando se ha trabajado por años consecutivos en la misma escuela, se intenta no elegir algún grupo que ya haya participado, se elige un grupo que no haya pasado por esta experiencia.

De esta manera, el docente de cine y el/la o los docentes de las escuelas se reúnen para discutir cómo van a ser las clases de cine, si hay algún lineamiento temático o conceptual que cada materia quiera trabajar, por lo general ligado al curriculum de la materia para ese grado, se planean y acuerdan cronogramas y actividades a realizar. Por ejemplo durante el año 2016 en la Escuela de Educación Media № 6 Distrito Escolar 5, la docente de literatura estuvo de acuerdo en vincular la propuesta de trabajar géneros cinematográficos y relacionarlos con los géneros literarios. Entre el docente de cine y la profesora de literatura se analizaron ideas como las de elegir adaptaciones que hayan pasado de la literatura al cine y reflexionar sobre sus similitudes y diferencias, o contrastar textos cortos con películas de un mismo género literario y cinematográfico, como por el ejemplo el suspenso o el terror.

Cuando inician las clases y ya se han acordado las actividades, horarios y fechas de inicio de las clases de CineZap, el docente de cine hace su llegada al aula para conocer al grupo con el cual se va a trabajar ese año. Dependiendo de la dinámica de cada docente, se hacen presentaciones de los estudiantes y del docente, se les explica cómo va a ser la dinámica de trabajo para las clases de cine; por lo general se pautan encuentros una vez por semana en el horario de la materia acordada.

El proceso o esquema de trabajo que se propone, inicia con la exploración de algunos conceptos básicos sobre cine y realización audiovisual, como por ejemplo: los géneros cinematográficos, qué es un cortometraje y sus características, diferencias entre la ficción y el documental, qué es un 
guión, cómo se construye una historia para un cortometraje y cuáles son las etapas de realización audiovisual. Esto puede tomar entre tres o cinco encuentros dependiendo de la dinámica de cada docente.

Posteriormente, para la realización del cortometraje, el primer paso es la creación de la historia; en esta etapa se les invita a todos los alumnos a proponer y escribir ideas que les gustaría trabajar, pueden partir de disparadores vinculados a los temas que están trabajando en las materias. Por ejemplo, en una de las escuelas la docente estaba trabajando el cuento "Casa tomada" de Julio Cortázar, partiendo de allí la docente propuso tomar ese texto como punto de partida, podían partir de un personaje, un lugar, una imagen o frase que les inspirara el cuento y de allí proponer una historia.

También está el caso de la escuela en donde se habían trabajado géneros cinematográficos y géneros literarios, los alumnos habían manifestado interés en el género de terror, ante esto los docentes les invitaron a leer cuentos de terror o suspenso, se analizaron algunas características propias de este género y luego se les propuso a los alumnos crear una historia corta de terror que pudiera ser contada en el cortometraje.

En los capítulos posteriores desarrollaré con más detalle cómo fue el proceso de CineZap en estas dos escuelas en las que participé. Pero a modo general, una de las cosas que pude observar, es que las reacciones o actitudes de los jóvenes ante esta primera etapa de creación son diversas, algunos sienten mayor motivación y muestran gran interés y destreza al momento de escribir, esto muchas veces está dado por el carácter de cada estudiante o por su predisposición ante las clases, por lo general quienes más se involucran en la escritura de la historia son alumnos aplicados y que promedian buenas notas en las materias.

Para la elección final de la historia se somete a discusiones de viabilidad en la realización y a votación con respecto a cuál es la que más gusta entre los alumnos, por lo general el autor de la 
historia, en equipo con dos o tres compañeros se van a encargar de escribir el guión para el cortometraje.

Cuando ya se tiene una idea seleccionada y el guión está en proceso de escritura, se profundiza en las etapas y cargos de la realización audiovisual. Se les que existe un momento previo a la grabación: la pre-producción, en donde se termina de escribir la historia y se consiguen todos los elementos necesarios para su realización, las locaciones, el vestuario, la utilería y los actores. Luego viene la etapa de producción, que es cuando se graban todas las escenas escritas en el guión y posteriormente la postproducción, donde se editan las escenas y se les da el orden que dice el guión, ya que, como algunos participantes ignoran al iniciar las clases, las escenas de cualquier producción audiovisual, no se graban en el orden que dice el guión, estas se organizan en un plan de grabación y se les da un orden dependiendo de facilidades técnicas y logísticas. Por ejemplo, se graban todas las escenas que transcurren en una misma locación, así en el guión estén intercaladas con otras escenas de otras locaciones; y es en el momento de la posproducción donde se le da ese orden narrativo a las escenas, se le agregan sonidos y música y los respectivos créditos de realización.

Con respecto a los cargos que los alumnos deben desempeñar para la realización del cortometraje, están divididos por departamentos: en el área de dirección, por lo general hay un director y un asistente o puede haber dos directores, en algunos casos puede ser el mismo guionista que se presupone es quién tiene más clara la historia. Está el departamento de fotografía o iluminación, pueden ser varios jóvenes que, dependiendo de la historia, se encargan de instalar luces o direccionar con ayuda de reflectores la luz solar para que las imágenes se vean de la manera deseada.

El área de vestuario, maquillaje y utilería está contemplado en el departamento de arte, son varios alumnos que se encargan de adecuar las locaciones, conseguir, muchas veces con ayuda de todo el grupo, los elementos necesarios para cada escena. El departamento de sonido, maneja los equipos de captura de audio como micrófonos y grabadoras de sonido. El departamento de cámara, es el encargado de manejar la cámara y grabar todas las escenas, en varios casos se decide que sean dos 
o tres alumnos, así de esta manera se pueden turnar en caso de que alguno falte y para que varios tengan la posibilidad de manipular la cámara.

Después de la explicación y ejemplificación de cada uno de los cargos, se hace un sondeo de qué cargo le gustaría desempeñar a cada uno. Los estudiantes se manifiestan y por lo general la decisión final es tomada después de haber asistido a una o dos salidas programadas a la Universidad del Cine (FUC), que como ya mencioné, ofrece sus espacios y equipos para las etapas de producción de las diferentes escuelas del programa CineZap. Allí realizan prácticas de algunas escenas de la historia en un estudio equipado con lo necesario para realizar una especie de simulacro o ensayo, los jóvenes tienen contacto con las cámaras, luces, micrófonos y equipos que van a usar en la grabación de su cortometraje; en este momento se modifica o reiteran las decisiones acerca de quién asume cada cargo, dependiendo de su desempeño durante estos ejercicios.

Como pude observar, durante esta etapa, algunos jóvenes se muestran incrédulos e indiferentes ante esta propuesta. Al parecer, para algunos, es desconcertante el hecho de que se les esté invitando a ser los autores y protagonistas de sus historias y se les esté poniendo a su disposición un despliegue logístico y tecnológico que usualmente no tienen en otras clases o en otros espacios cercanos a su cotidianidad. Ante esto puede surgir duda o desconfianza, Luna reflexiona al respecto:

“Cuando se les dice que van a tener la posibilidad de hacer un video, que tendrán a su cargo tecnología como las que usan los profesionales, o que sus trabajos se exhibirán en una sala cinematográfica comercial, aparece la mirada desconfiada, la incredulidad. Ubicados los adolescentes en el lugar de la expulsión, creen que algo así no les puede tocar. Tal vez piensan que la realización del video se convertirá en una de las tantas promesas incumplidas que han recibido ellos y sus familias" (Luna, 2012, p.207) 
Esta reflexión acerca de las posibilidades y los lugares sociales de los jóvenes que asisten a las escuelas medias del sur de la ciudad, pone en evidencia que quienes participan de este proceso, son jóvenes que se ven directa o indirectamente afectados por las condiciones económicas y sociales en las que viven, pero sobre todo, por el estigma que recae sobre ellos y el refuerzo de su entorno social. Esto les lleva, muchas veces a negarse la posibilidad de acceder a oportunidades como las que brinda el programa CineZap, o más profundamente a la posibilidad de ser ellos mismos quienes cuenten sus historias a los demás.

Otro momento importante durante la pre-producción o preparación de la grabación es la elección de los actores, quienes van a representar a los personajes de las historias que crearon. Este es un momento de gran debate y discusión para el grupo, porque según pude observar, se presentan casos en donde voluntariamente se postulan jóvenes, porque se sienten cómodos actuando, pero en otros casos por presión del grupo, se le insiste a algún participante que actúe porque sus compañeros le consideran el más lindo o linda, simpática o simpático del grupo.

Esta decisión por lo general desata debates y discusiones entre los jóvenes, algunas veces dejan ver riñas o preferencias marcadas por la amistad o la enemistad existente entre los miembros del grupo. En un caso en particular, en una de las escuelas, un joven muy tímido, llamado Ismael, que participaba poco en clases, decidió postularse como protagonista del corto ante la mirada incrédula de sus compañeros, la directora del cortometraje, que en este caso era la misma joven que había escrito la historia, le consideraba muy tímido y torpe para desempeñar el papel y trató de persuadirlo a él y a sus compañeros, pero ya que no había otro candidato, este joven quedó seleccionado. Unos días más tarde, entró al grupo un joven nuevo, que rápidamente tuvo simpatía con el grupo, era muy activo y hablador, la directora del cortometraje y algunos compañeros le persuadieron de ser el actor protagonista, lo sometieron a votación y quedó elegido el estudiante nuevo.

Días antes de la grabación de las primeras escenas, este joven se pelea con otros compañeros de la escuela y deja de asistir a clases, ante su ausencia deben recurrir a Ismael, el joven tímido que se 
había postulado inicialmente. Ante la incredulidad de la directora, durante la grabación, este chico muestra gran destreza frente a la cámara y demuestra conocer perfectamente la historia, las escenas y los diálogos, lo cual genera un cambio de actitud en la directora y en algunos de sus compañeros.

Esta situación es un ejemplo de la tensión que se vivencia cuando se promueve la participación, el trabajo en equipo y ante todo los espacios de confianza, cuando en una dinámica alternativa a la que usualmente promueve la escuela, se propician espacios para el empoderamiento y surgen estos debates que les permiten a los jóvenes reconocerse entre ellos, identificar por ellos mismos sus capacidades y confiar en sus potenciales, estos espacios de transformación (Huergo, 2007), son posibles, en gran medida, por la dinámica misma del programa CineZap, que promueve la participación y el compromiso, transformando las relaciones interpersonales de quienes hacen parte del proceso, en palabras de Luna:

"Durante el transcurso de las distintas etapas del proyecto, se hace hincapié en que la participación y el compromiso de los alumnos son imprescindibles. Ellos deben consolidarse como gestores y realizadores; sin ellos no es posible realizar el cortometraje. Y una de las bases para la implicación y la participación, es la estimulación de la confianza del alumno en sí mismo. Su opinión y punto de vista valen no porque así se lo enuncie, sino porque a medida de que la tarea avanza, el grupo lo vivencia. La delegación de la toma de decisiones en ellos es una de las pruebas." (Luna, 2012, p.213)

El momento de la grabación, es una de las etapas que mayor expectativa genera en los participantes. Tras haber planeado con varias semanas de anticipación cada uno de los detalles para la grabación, salir del aula y de la escuela, empoderarse de los equipos y de la toma de decisiones, son algunas de las experiencias que más recuerdan los estudiantes, según me comentaron algunos chicos meses después. 
Les permite romper con las estructuras rígidas del espacio áulico y les propone un espacio de autonomía (Gauna, 2014), saben que si no aprovechan al máximo el tiempo y los espacios para grabar las escenas planteadas, no van a poder llevar a término su cortometraje, este último concepto es importante, ya que a este punto los jóvenes lo contemplan como un proyecto propio, se responsabilizan y toman conciencia de que el resultado que se verá en la pantalla será el reflejo del desempeño y el compromiso que pongan en cada una de sus acciones.

Por supuesto, adquiere también un carácter de distensión y de disfrute, al compartir esta experiencia nueva para ellos y estar en espacios que no corresponden a los límites fisicos de la escuela. Adoptan una actitud más relajada y de alguna manera les permite mostrar conductas que usualmente no exteriorizan dentro del aula, ejemplos como hacerse bromas o chistes, tomarse un tiempo para sentarse a conversar, compartir una merienda en grupo, discutir sobre las anécdotas de la experiencia de la grabación, entre otros, son momentos de goce y de dispersión que los jóvenes recuerdan con entusiasmo.

La etapa final de la realización audiovisual, es la post-producción allí, como ya mencioné, se seleccionan las escenas que van a formar el cortometraje, se les da el orden deseado, se retoca el color, se introducen los sonidos, diálogos y musicalización; en la mayoría de los casos, la música es elegida por los jóvenes. Este proceso se lleva a cabo en salas de edición dispuestas por la Fundación Universidad del Cine, que también pone a disposición de cada grupo, estudiantes avanzados de las carreras de cine, para ayudar a los jóvenes a concretar el proceso de edición de su cortometraje.

Esta etapa es de gran importancia, ya que es el momento en que ven materializado todo su trabajo, lo que en algún momento creyeron imposible o inviable, ahora es una realidad, es un cortometraje hecho por ellos mismos. Es una etapa de gran expectativa, en algunos casos, puede suceder que la historia no sea lo que se imaginaron en un comienzo o que haya algunas inconsistencias narrativas, lo cual es usado también para reflexionar y analizar aspectos que podrían llegar a mejorarse en un 
futuro. Les permite comprender desde la práctica, el reto de contar con imágenes y sonidos, y a su vez, les posibilita el lugar de protagonistas.

Esto pone la mirada de la creación audiovisual no tanto en el resultado, en la calidad técnica o narrativa del cortometraje, sino que releva el proceso, la experiencia de transitar por una dinámica de creación y experimentación, de la cual se han empoderado; "nos interesa el tránsito por la experiencia, el proceso, más que la calidad del producto final. Por ello, las intervenciones de los adultos son a modo de guía, coordinación y motivación.” (Luna, 2012, p.208)

Al finalizar el año lectivo se realiza una muestra en la escuela, por lo general vinculada a eventos de cierre del periodo escolar, en donde también se exponen trabajos de otras materias o presentaciones musicales o artísticas. En otros casos puede prepararse una exhibición específica para el cortometraje, pero tradicionalmente, el programa CineZap realiza una proyección de cierre con todas las escuelas que participaron y se invita a los jóvenes y a sus familias a ver los cortometrajes. Esto genera gran expectativa, sus familiares y conocidos los van a ver actuar o saben que ellos participaron en esos videos. Algunos jóvenes me comentaban, que creen que sus padres se van a sentir orgullosos y otros temen que sus amigos o compañeros se rían de ellos, en especial de los jóvenes que actuaron.

\subsection{Escena 6 - Ext - día - Las temáticas: el lenguaje y la palabra}

Partiendo de la premisa, de que este programa promueve la expresión y la posibilidad de que sus participantes hablen de sus realidades, es posible pensar que las temáticas más recurrentes plasmadas en estos cortometrajes son: la violencia, las drogas, el embarazo no deseado, entre otros. Si bien estos temas si están presentes en algunas de los cortometrajes de estas escuelas, no es una generalidad y tampoco es una prioridad o un lineamiento del programa CineZap, abordar específicamente las problemáticas mencionadas, al respecto Luna comenta: 
"Uno de los objetivos del proyecto es que los alumnos desarrollen su expresividad. Por eso, nos situamos en la propuesta en el lugar de escucha. Ante la finalidad expresiva no buscamos un resultado en torno a una temática en particular ni homogeneidad en los asuntos de las narraciones sino que, por el contrario, propiciamos la diversidad: ¿Qué tienen para decirnos nuestros jóvenes? ¿Qué historias quieren contar? El valor está puesto en su discurso, en sus intereses, en sus puntos de vista. Buscamos resultados idiosincrásicos, no la repetición de opiniones o juicios condicionados.” (Luna, 2012, p.206)

Como me comentaba Cristian y reafirma Luna, el programa CineZap, desde sus posturas políticas y pedagógicas, no plantea una única exploración temática en las construcciones narrativas de los cortometrajes, los docentes de cine parten de la convicción de que la creación audiovisual, posibilita espacios amplios de reflexión y variedad de temáticas y enfoques narrativos, "creemos no equivocarnos al afirmar que la representación simbólica audiovisual de las temáticas sociales que preocupan a los adolescentes les permiten sistematizar y aclarar sus pensamientos sobre ellas, y estar de ésta manera más preparados para afrontarlas" (Luna, 2012, p.210).

Ante esto, planteo una reflexión acerca de las temáticas, no desde la mirada de cuáles son las problemáticas más evidenciadas, sino a partir de cómo el programa CineZap, desde su práctica posibilita el diálogo, la discusión y la reflexión sobre las realidades de quienes participan (Huergo, 2007).

Reflexiones con respecto al empoderamiento y la posibilidad de transformación, son algunas de las bases que constituyen al campo comunicación/educación. Paulo Freire re configura el concepto de palabra, de discurso; que para términos de esta investigación, involucra todo tipo de lenguaje, particularmente el audiovisual. La palabra, el lenguaje, el discurso narrativo plasmado en cada uno de los cortometrajes, es una de las armas más importantes dentro de la identificación y empoderamiento de los sujetos dentro de los cambios políticos y culturales, "los hombres no se 
hacen en el silencio, sino en la palabra, en el trabajo, en la acción, en la reflexión" (Freire, 1970, p.12).

Para ello se plantea en el reconocimiento y el diálogo, pilares de las reflexiones y prácticas de lo que Huergo analiza posteriormente cómo horizontes del campo, dejando ver la presencia de conceptos como la dialogicidad, que Freire define como el trabajo interrelacional entre la acción y la reflexión, lo cual va a dar como resultado la praxis (Freire, 1970)

En el momento mismo en el que los jóvenes que participan del programa CineZap empiezan a crear sus historias, están tomando como referencia sus vivencias, sus recuerdos, percepciones del mundo e idiosincrasias. Aunque se repliquen formatos, esquemas o tratamientos cinematográficos o televisivos, lo que allí reflejan es su mirada del mundo, cuando se les invita a crear se les invita también a reflexionar, a pensar y repensarse a sí mismos y a su entorno, como lo dice Huergo: "El trabajo con el nivel del reconocimiento es lo que hace posible la identificación del mundo narrado en el producto cultural audiovisual con el mundo del receptor popular. Todo producto cultural audiovisual habla al pueblo del que habla." (Huergo, 1997, p.25), es decir, todas las historias que los estudiantes construyen, aunque sean de ficción, les identifican y les manifiestan desde su lugar y desde su visión del mundo.

Posicionando nuevamente al programa CineZap dentro del campo comunicación/educación, reconocemos en él, apuestas y acciones políticas que promueven la transformación del individuo y de su universo cultural, en donde se identifican acciones de carácter colectivo, de reflexión y de creación que no solamente involucran una exploración de un tema a tratar, en el caso de las historias de los cortometrajes, sino que trasciende a una oportunidad de compartir, aprender y generar procesos de transformación, "la investigación temática se hace así, un esfuerzo común de toma de conciencia de la realidad y la autoconciencia, que la inscribe como punto de partida del proceso educativo o de la acción cultural de carácter liberador” (Freire, 1970, p.18) 
El momento de la elección del tema y la historia a contar en los cortometrajes, es siempre una etapa que representa para los jóvenes una oportunidad no muy usual dentro de las dinámicas tradicionales de la escuela, es un llamado a pensarse a sí mismos, a su realidad y plasmarla en una historia de ficción, lo que les ofrece una alta gama de posibilidades de representar su visión del mundo adornada con diferentes herramientas narrativas, según Luna:

"Es evidente que a los jóvenes la realidad cotidiana les pesa, les preocupa y quieren intervenir modificándola. Cuando tienen la oportunidad de hablar sobre algo eligen hablar de ella y con un sentido comprometido. Las inquietudes humanitarias que trasuntan sus miradas son muy alentadoras y ejemplificadoras para una sociedad que suele tildarlos de superficiales y descomprometidos. De esta manera, los videos, las producciones audiovisuales, se convierten en un lugar de encuentro social en donde los jóvenes sistematizan sus miradas, se acercan entre ellos y permiten acercarnos a ellos compartiendo el trabajo y comprendiendo sus configuraciones narrativas." (Luna, 2012, p.207)

\subsection{Escena 7 - Ext - día - Los Cortometrajes}

Para analizar a profundidad las temáticas abordadas en los cortometrajes, visualicé y conceptualice los productos audiovisuales realizados en años anteriores, en estas dos escuelas donde realicé mi trabajo de campo. Todos los cortometrajes están disponibles en el sitio web oficial de CineZap: www.cinezap.com.ar

De la Escuela E.E.M. 6 D.E. 5 Polo Educativo Barracas, visualicé los 6 cortometrajes que se realizaron entre los años 2009 y 2015, los cuales sistematizo a continuación: 
Escuela E.E.M. 6 D.E. 5 Polo Educativo Barracas

\begin{tabular}{|c|c|c|}
\hline $\begin{array}{c}\text { FICHA TÉCNICA } \\
\text { (Tomada del sitio web } \\
\text { de CineZap) }\end{array}$ & $\begin{array}{c}\text { SINOPSIS } \\
\text { (Tomada del sitio web de } \\
\text { CineZap) }\end{array}$ & TEMAS Y SUBTEMAS \\
\hline $\begin{array}{l}\text { Título del corto: El } \\
\text { sueño de Maia } \\
\text { Escuela: E.E.M. } 6 \text { D.E. } \\
5 \text { Polo Educativo } \\
\text { Barracas } \\
\text { Año de realización: } \\
2009 \\
\text { Director/es: Isabel } \\
\text { Sánchez } \\
\text { Duración: } 12 \text { min. }\end{array}$ & $\begin{array}{l}\text { La familia de Maia logra una } \\
\text { armonía inusual sedimentada en } \\
\text { el compartir y en el esfuerzo } \\
\text { cotidiano de todos sus } \\
\text { integrantes. Maia está a cuatro } \\
\text { meses de cumplir sus quince } \\
\text { años y el sueño de toda su vida: } \\
\text { festejarlos con una gran fiesta. } \\
\text { De pronto, esta armonía entra en } \\
\text { crisis por circunstancias que les } \\
\text { obligará tanto a replantearse } \\
\text { caminos en búsqueda de la mejor } \\
\text { salida, como también, a aceptar } \\
\text { cambios para siempre. }\end{array}$ & $\begin{array}{l}\text { Condiciones socio- } \\
\text { económicas. } \\
\text { La idea del sacrificio por } \\
\text { una mejor vida. } \\
\text { Relevancia de eventos } \\
\text { sociales, como la "fiesta de } \\
15 \text { años" }\end{array}$ \\
\hline $\begin{array}{l}\text { Título del corto: } \mathrm{Mi} \\
\text { amiga ama el dolor } \\
\text { Escuela: E.E.M. } 6 \text { D.E. } \\
5 \text { Polo Educativo } \\
\text { Barracas } \\
\text { Año de realización: } \\
2010 \\
\text { Dirección: Jonathan } \\
\text { Alegre }\end{array}$ & $\begin{array}{l}\text { A pesar del esfuerzo que hacen } \\
\text { las amigas de Mariela para } \\
\text { abrirle los ojos respecto a los } \\
\text { engaños de su novio Cachu, ella } \\
\text { no puede aceptarlo. Aunque los } \\
\text { acontecimientos pasan frente a } \\
\text { su cara, sigue insistiendo en que } \\
\text { él la ama. Las amigas organizan } \\
\text { una fiesta para obligarla a }\end{array}$ & $\begin{array}{l}\text { Relaciones adolescentes, } \\
\text { los noviazgos, la } \\
\text { infidelidad, la amistad. } \\
\text { El respaldo de los amigos } \\
\text { funciona como código. } \\
\text { Códigos sociales en donde } \\
\text { se pone en juego la } \\
\text { amistad y la fidelidad. } \\
\text { El refuerzo del estereotipo }\end{array}$ \\
\hline
\end{tabular}




\begin{tabular}{|c|c|c|}
\hline Duración: 7 min. & $\begin{array}{l}\text { aceptar la dolorosa evidencia que } \\
\text { todos conocen. Carlos, un nuevo } \\
\text { personaje aparece en acción } \\
\text { ayudando a Mariela a poner las } \\
\text { cosas en el lugar debido. }\end{array}$ & $\begin{array}{l}\text { del hombre infiel y } \\
\text { mujeriego. }\end{array}$ \\
\hline $\begin{array}{l}\text { Título del corto: La } \\
\text { Mancha } \\
\text { Escuela: E.E.M. } 6 \text { D.E. } \\
5 \text { Polo Educativo } \\
\text { Barracas } \\
\text { Año de realización: } \\
2011 \\
\text { Dirección: Marcia } \\
\text { Barrios Melgarejo } \\
\text { Producción: Noelia } \\
\text { Albarracin } \\
\text { Duración: } 9 \text { minutos }\end{array}$ & $\begin{array}{l}\text { Elizabeth no puede encontrar a } \\
\text { su novio Esteban, con quien } \\
\text { convive. En cambio, encuentra } \\
\text { en su casa una mancha de sangre. } \\
\text { Nadie parece creerle en su } \\
\text { angustia y demanda de ayuda. } \\
\text { ¿Hay alguna relación entre } \\
\text { Esteban y la mancha? La } \\
\text { respuesta que puede darnos } \\
\text { Elizabeth está agazapada en los } \\
\text { pliegues del borde entre la vigilia } \\
\text { y el sueño, el desamparo y la } \\
\text { locura }\end{array}$ & Crimen, asesinato, locura \\
\hline $\begin{array}{l}\text { Título del corto: } \\
\text { Resistencia } \\
\text { Escuela: EEM } 6 \text { DE } 5 \\
\text { Polo Educativo } \\
\text { Barracas } \\
\text { Año de realización: } \\
2013 \\
\text { Dirección: Gustavo } \\
\text { Silva }\end{array}$ & $\begin{array}{l}\text { El intento de erradicación } \\
\text { violenta de las villas de } \\
\text { emergencia de la Ciudad de } \\
\text { Buenos Aires fue una de las } \\
\text { tantas aberraciones y atropellos } \\
\text { que cometió la última dictadura } \\
\text { militar en la Argentina. } \\
\text { "Resistencia" es la historia de un } \\
\text { grupo de militantes de la villa } \\
21-24 \text { que, durante el año } 1978, \\
\text { intenta organizar a los vecinos }\end{array}$ & $\begin{array}{l}\text { Reconocimientos de } \\
\text { hechos históricos. } \\
\text { Deseo de validación de } \\
\text { actos de resistencia frente } \\
\text { a la dictadura cívico } \\
\text { militar de la Argentina. } \\
\text { La memoria }\end{array}$ \\
\hline
\end{tabular}




\begin{tabular}{|c|c|c|}
\hline & $\begin{array}{l}\text { para resistir este siniestro } \\
\text { proyecto, arriesgando todo lo que } \\
\text { tienen por una causa justa, } \\
\text { siendo capaces de arriesgar hasta } \\
\text { la propia vida. }\end{array}$ & \\
\hline $\begin{array}{l}\text { Título del corto: El } \\
\text { pomberito } \\
\text { Escuela: EEM } 6 \text { DE } 5 \\
\text { Polo Educativo } \\
\text { Barracas } \\
\text { Año de realización: } \\
2014 \\
\text { Dirección: "Marcos } \\
\text { Daniel Ortiz Gonzalez" } \\
\text { Duración: } 10 \text { minutos }\end{array}$ & $\begin{array}{l}\text { El Pomberito es uno de los tantos } \\
\text { mitos populares guaraníes. Para } \\
\text { Nicolás simplemente "son todas } \\
\text { mentiras" así que no tendrá } \\
\text { problemas en llamarlo con su } \\
\text { silbido... ¿Mito, leyenda o } \\
\text { realidad? }\end{array}$ & $\begin{array}{l}\text { Cultura popular, creencias } \\
\text { populares, de origen } \\
\text { guaraní, evidencia una } \\
\text { marcada presencia de } \\
\text { nacidos o descendientes de } \\
\text { paraguayos estudiando en } \\
\text { la escuela. Transmisión de } \\
\text { creencias populares de } \\
\text { manera oral de generación } \\
\text { en generación. Aceptación } \\
\text { de las raíces paraguayas. } \\
\text { Tradición rural vs } \\
\text { escepticismo urbano }\end{array}$ \\
\hline $\begin{array}{l}\text { Título del corto: } \\
\text { Buscando la salida } \\
\text { Escuela: EEM } 6 \text { DE } 5 \\
\text { Polo Educativo } \\
\text { Barracas } \\
\text { Año de realización: } \\
2015 \\
\text { Dirección: Rocío } \\
\text { Benítez } \\
\text { Duración: } 11 \text { minutos }\end{array}$ & $\begin{array}{l}\text { A veces, cuando uno se } \\
\text { encuentra sólo y las } \\
\text { circunstancias no son favorables } \\
\text { se corre el riesgo de optar por } \\
\text { caminos que, en apariencia, } \\
\text { parecen fáciles. Gael no mide las } \\
\text { consecuencias de su decisión. } \\
\text { Pero aún en los momentos más } \\
\text { difíciles siempre hay alguien } \\
\text { dispuesto a dar una mano y } \\
\text { ayudar a buscar una salida. }\end{array}$ & $\begin{array}{l}\text { Las drogas, consumo y } \\
\text { expendio como salida fácil } \\
\text { de los problemas } \\
\text { económicos y afectivos. } \\
\text { Apoyo y respaldo de las } \\
\text { instituciones como la } \\
\text { respuesta políticamente } \\
\text { correcta, mirada positiva } \\
\text { frente a las instituciones. } \\
\text { La relación docente - } \\
\text { alumno en la ayuda a los }\end{array}$ \\
\hline
\end{tabular}


Y de la E.E.T. 17 D.E. 13 "Brig. Gral. Don Cornelio de Saavedra", sistematizo los 8 cortometrajes realizados entre 2001 y 2016 :

\begin{tabular}{|c|c|c|}
\hline \multicolumn{3}{|c|}{ E.E.T. 17 D.E. 13 "Brig. Gral. Don Cornelio de Saavedra" } \\
\hline $\begin{array}{l}\text { FICHA TÉCNICA } \\
\text { (Tomada del sitio web } \\
\text { de CineZap) }\end{array}$ & $\begin{array}{c}\text { SINOPSIS } \\
\text { (Tomada del sitio web de } \\
\text { CineZap) }\end{array}$ & TEMAS Y SUBTEMAS \\
\hline $\begin{array}{l}\text { Título del corto: } \\
\text { Mortero Mortal } \\
\text { Escuela: Escuela } \\
\text { Técnica No } 17 \text { D. E. } 13 \\
\text { “Brig. Gral. don } \\
\text { Cornelio de Saavedra" } \\
\text { Año de realización: } \\
2001 \\
\text { Dirección: Maria Paula } \\
\text { Sarmiento } \\
\text { Duración: } 11 \text { min }\end{array}$ & $\begin{array}{l}\text { Cecilia y Fernando quieren } \\
\text { construir un par de cuartos en el } \\
\text { piso superior de su casa. Gastón } \\
\text { es un amigo de Fernando que se } \\
\text { encarga de hacer estos trabajos. } \\
\text { Las cosas no son tan sencillas y } \\
\text { cuando surgen los primeros } \\
\text { inconvenientes, los tres } \\
\text { empiezan a mostrar su costado } \\
\text { más oculto. }\end{array}$ & $\begin{array}{l}\text { Se desarrolla en el } \\
\text { ambiente de la } \\
\text { construcción. Género, } \\
\text { homosexualidad. } \\
\text { Relaciones de pareja, } \\
\text { engaño. Final inesperado. } \\
\text { Tema tabu año } 2001\end{array}$ \\
\hline $\begin{array}{l}\text { Título del corto: El } \\
\text { Plan } \\
\text { Escuela: Escuela } \\
\text { Técnica N } 17 \text { D. E. } 13 \\
\text { "Brig. Gral. don } \\
\text { Cornelio de Saavedra" } \\
\text { Año de realización: }\end{array}$ & $\begin{array}{l}\text { La ingenuidad y la falta de } \\
\text { escrúpulos son los ingredientes } \\
\text { esenciales que tejen esta historia } \\
\text { en torno al objetivo de Facundo: } \\
\text { aprobar matemática. }\end{array}$ & $\begin{array}{l}\text { El ambiente escolar. } \\
\text { La relación docente } \\
\text { alumno, la maestra se } \\
\text { enamora del alumno. } \\
\text { El engaño }\end{array}$ \\
\hline
\end{tabular}




\begin{tabular}{|c|c|c|}
\hline $\begin{array}{l}2002 \\
\text { Director/es: Ariel } \\
\text { Mariosa } \\
\text { Duración: } 11 \mathrm{~min} \text {. }\end{array}$ & & \\
\hline $\begin{array}{l}\text { Título del corto: Por } \\
\text { Traición } \\
\text { Escuela: Escuela } \\
\text { Técnica N } 17 \text { D. E. } 13 \\
\text { "Brig. Gral. don } \\
\text { Cornelio de Saavedra" } \\
\text { Año de realización: } \\
2003 \\
\text { Director/es: Alejandro } \\
\text { Ezequiel Banegas } \\
\text { Bagnati } \\
\text { Duración: } 9 \text { min. }\end{array}$ & $\begin{array}{l}\text { Una escuela es un lugar de } \\
\text { socialización, juegos y } \\
\text { aprendizaje. Pero, también puede } \\
\text { encerrar el pasado más oscuro. } \\
\text { Adrián vuelve a su escuela de la } \\
\text { adolescencia, esta vez, como } \\
\text { profesor. No puede evitar } \\
\text { encontrarse con Fabián, su } \\
\text { compañero de antaño. }\end{array}$ & $\begin{array}{l}\text { Escuela técnica, todos } \\
\text { hombres, juegos violentos } \\
\text { y agresivos como } \\
\text { manifestación de la } \\
\text { masculinidad. } \\
\text { Figura de autoridad del } \\
\text { docente. } \\
\text { Lo paranormal, fantasmas. } \\
\text { El pasado. }\end{array}$ \\
\hline $\begin{array}{l}\text { Título del corto: La } \\
\text { Mentira } \\
\text { Escuela: Escuela } \\
\text { Técnica N } 17 \text { D. E. } 13 \\
\text { "Brig. Gral. don } \\
\text { Cornelio de Saavedra" } \\
\text { Año de realización: } \\
2004 \\
\text { Director/es: Bruno } \\
\text { Lezcano } \\
\text { Duración: } 8 \text { min. }\end{array}$ & $\begin{array}{l}\text { Andrea es capaz de inventar } \\
\text { cualquier artilugio para atraer la } \\
\text { atención de Franco. Finalmente, } \\
\text { su actuación de pitonisa parece } \\
\text { estar a punto de lograrlo. Su } \\
\text { voluntad escudada tras unas } \\
\text { cartas de tarot dibuja, mentira } \\
\text { tras mentira, una realidad a la } \\
\text { medida de sus deseos. Parece } \\
\text { que ellas mismas cobran vida } \\
\text { poniendo al destino en línea con } \\
\text { la voluntad de Andrea. }\end{array}$ & $\begin{array}{l}\text { Los amigos, el engaño, las } \\
\text { relaciones adolescentes. Lo } \\
\text { trágico, la muerte como } \\
\text { final más recurrente. }\end{array}$ \\
\hline
\end{tabular}




\begin{tabular}{|c|c|c|}
\hline $\begin{array}{l}\text { Título del corto: } \\
\text { Consecuencias } \\
\text { Escuela: Escuela } \\
\text { Técnica N } 17 \text { D. E. } 13 \\
\text { "Brig. Gral. don } \\
\text { Cornelio de Saavedra" } \\
\text { Año de realización: } \\
2007 \\
\text { Dirección: German } \\
\text { Suarez } \\
\text { Duración: } 10 \text { min }\end{array}$ & $\begin{array}{l}\text { Generalmente, los celos no son } \\
\text { buenos consejeros. En un } \\
\text { contexto de abandonos y miseria, } \\
\text { Mariana recurre a la mentira y a } \\
\text { la manipulación para convertir a } \\
\text { Christian en el compañero de su } \\
\text { propia aventura. Como sucede } \\
\text { habitualmente, un par de cabos } \\
\text { escapan a su control. }\end{array}$ & $\begin{array}{l}\text { Embarazo en adolescentes. } \\
\text { Relaciones de pareja en la } \\
\text { juventud. } \\
\text { La maternidad como } \\
\text { conflicto. } \\
\text { Madres solteras. }\end{array}$ \\
\hline $\begin{array}{l}\text { Título del corto: \#767 } \\
\text { Escuela: Escuela } \\
\text { Técnica N } 17 \text { D. E. } 13 \\
\text { "Brig. Gral. don } \\
\text { Cornelio de Saavedra" } \\
\text { Año de realización: } \\
2008 \\
\text { Director/es: Braian } \\
\text { Salvatierra } \\
\text { Duración: } 8 \text { min. }\end{array}$ & $\begin{array}{l}\text { Una cita amorosa y el crimen de } \\
\text { Laura, son el punto de partida de } \\
\text { un interrogatorio policial que } \\
\text { deja al descubierto un círculo } \\
\text { vicioso. }\end{array}$ & $\begin{array}{l}\text { El asesinato y el crimen. } \\
\text { La muerte. } \\
\text { La violencia. }\end{array}$ \\
\hline $\begin{array}{l}\text { Título del corto: } \\
\text { Identidad Tomada } \\
\text { Escuela: Escuela } \\
\text { Técnica No } 17 \text { D. E. } 13 \\
\text { "Brig. Gral. don } \\
\text { Cornelio de Saavedra" } \\
\text { Año de realización: } \\
2015\end{array}$ & $\begin{array}{l}\text { Identidad Tomada... Es la } \\
\text { historia de Ricardo Paredes, un } \\
\text { buen trabajador, capataz de obra } \\
\text { que decide cambiar su vida con } \\
\text { un golpe de "suerte" inesperado } \\
\text { tras la muerte de su jefe...pero } \\
\text { sus cálculos no resultaran } \\
\text { exactos. Nunca se sabe qué }\end{array}$ & $\begin{array}{l}\text { Diferencia de clase social, } \\
\text { el arquitecto visto como el } \\
\text { "cheto" o de mayor estatus } \\
\text { social y los obreros o el } \\
\text { capataz como de menor } \\
\text { rango. El deseo de ascenso } \\
\text { o movilidad social. La } \\
\text { codicia, el dinero como }\end{array}$ \\
\hline
\end{tabular}




\begin{tabular}{|c|c|c|}
\hline $\begin{array}{l}\text { Dirección: Leonel } \\
\text { Yucra } \\
\text { Duración: } 15 \text { minutos }\end{array}$ & $\begin{array}{l}\text { implica estar en los zapatos de } \\
\text { otro. }\end{array}$ & móviles del crimen. \\
\hline $\begin{array}{l}\text { Título del corto: La } \\
\text { Toma } \\
\text { Escuela: Escuela } \\
\text { Técnica No } 17 \text { D. E. } 13 \\
\text { “Brig. Gral. don } \\
\text { Cornelio de Saavedra" } \\
\text { Año de realización: } \\
2016 \\
\text { Dirección: Nahuel } \\
\text { Ramos, Federico Spina, } \\
\text { Ezequiel Videla, Uriel } \\
\text { Saggese, Rube } \\
\text { Romerofer } \\
\text { Duración: } 7 \text { mins } \\
\text { (aprox) }\end{array}$ & $\begin{array}{l}\text { Martín Urquía es un joven } \\
\text { periodista que tiene que ir a } \\
\text { cubrir la toma de una fábrica } \\
\text { para el noticiero en el que } \\
\text { trabaja. Al principio se niega } \\
\text { porque considera que los } \\
\text { trabajadores son peligrosos y } \\
\text { violentos. Acepta y la cobertura, } \\
\text { cambiara su mirada sobre la } \\
\text { toma de la fábrica y sobre } \\
\text { algunos aspectos de la vida. }\end{array}$ & $\begin{array}{l}\text { Personas privilegiadas, } \\
\text { estudios en instituciones } \\
\text { privadas, bilingües. Hijo } \\
\text { único. Protestas y toma de } \\
\text { la fábrica por el reclamo de } \\
\text { un mejor trabajo. } \\
\text { Represión policial. } \\
\text { Solidaridad. Contraste de } \\
\text { estatus social, persona de } \\
\text { estatus social más alto } \\
\text { solidarizándose con } \\
\text { obreros de la fábrica. }\end{array}$ \\
\hline
\end{tabular}

La posibilidad de identificar y materializar una realidad latente y tratar de proponer desde la ficción, una alternativa más positiva o menos violenta, es uno de los objetivos que parece promover el programa. Este puede ser el caso del cortometraje: Buscando la salida, realizado durante el 2015 en la EEM 6 DE 5. En donde un alumno de la escuela, se siente solo, no recibe apoyo de su familia ni amigos, entonces otro joven le propone vender drogas en la escuela y el barrio. Inicialmente este se niega, pero impulsado por su situación de desamparo, al final acepta. Esto lo lleva a desmejorar en la escuela y a volverse más conflictivo y violento. Hasta que un día es perseguido y buscado por la policía, pero encuentra en los docentes de la escuela un apoyo, ellos le brindan ayuda ante su situación. 
Este cortometraje es un planteo de la realidad que viven algunos de estos jóvenes, el desapego y falencias en las relaciones familiares, el expendio y consumo de droga en sus círculos más cercanos y la desconfianza frente a las entidades públicas. Estas temáticas son recurrentes en el día a día de los estudiantes de estas escuelas públicas. El debate y la discusión frente a la propuesta de alternativas diferentes a la violencia o la muerte, son una invitación a pensar que en su vida cotidiana pueden tener el apoyo de sus familiares, amigos y particularmente de sus profesores o directivos. Esto representa un replanteo de las relaciones docente - alumno, en donde se le concede al otro un lugar de igualdad, de respeto y de compromiso (Huego, 2007), partir de estos planteamientos promueven una transformación de las relaciones y la dinámica escolar, que es uno de los aspectos a los que CineZap apunta a construir.

Lejos de creer que todos los cortometrajes resultado de las clases de CineZap, abordan estas temáticas, se encuentra gran variedad en los temas y los tratamientos que se les dan a las historias que ellos construyen, por ejemplo, el reconocimiento al trabajo, al esfuerzo, la unidad familiar, el amor y el sacrificio, son materializados en el cortometraje: El sueño de Maia, realizado durante el 2009 en la EEM 6 DE 5. Cuenta la historia de una joven que está próxima a cumplir sus 15 años y sueña con una gran fiesta para celebrarlos, la situación económica de su familia es complicada, los ingresos del padre les alcanzan para vivir al límite, pero el sacrificio de este hombre por cumplir el sueño de su hija le lleva a trabajar horas extras, lo cual lo agota hasta el punto de provocarle la muerte. Si bien, el final es violento, el tratamiento que se le da esta desde el amor y el sacrificio, un padre que hace lo que sea, hasta dar su vida por su familia, parece una invitación a valorar lo que se tiene, los vínculos familiares y el amor de los padres.

Otro caso que se vincula más con el reconocimiento de las tradiciones de sus lugares de origen, es el cortometraje: El pomberito, realizado durante el 2014 en la EEM 6 DE 5. Con una inmersión en el género de terror, busca rescatar un mito originario del Paraguay. Narra la historia de un joven que no cree en la existencia de un ser sobrenatural llamado "Pomberito", su escepticismo es puesto a prueba cuando es víctima de sucesos sobrenaturales que le llevan a creer en la existencia de este 
ser. Esto, además de hablar del origen de gran parte de los estudiantes de estas escuelas, cuyos padres, familiares cercanos o incluso ellos han nacido en países limítrofes como Paraguay, Bolivia o Perú, conlleva a una reflexión más profunda acerca de la aceptación de las tradiciones de sus raíces, sobrepasando los estereotipos y los estigmas de los cuales son víctimas los jóvenes que provienen de estos países.

Los estereotipos, estigmas sociales o de género también han sido tratados en el programa CineZap, el cortometraje: Mortero Mortal, realizado durante el 2001 en la escuela Técnica Número 17 Brigadier General Don Cornelio de Saavedra, tiene un planteamiento narrativo llamativo, la historia inicia con una pareja que contacta a un contratista para que les ayude a construir una habitación en el segundo piso de su casa, tras coordinar reuniones para llevar a cabo la obra, se sugiere que la mujer y el contratista inician una relación amorosa. Ante el desconocimiento del esposo, un día la mujer y el contratista van a ver los avances de la obra e inesperadamente éste la empuja a un cilindro de mezcla y ella muere, luego vemos al contratista y al esposo alejarse caminando tomados de la mano.

La propuesta de mostrar explícitamente la homosexualidad en un producto audiovisual, quizás no era tan común como en la actualidad y probablemente la estigmatización al respecto, en el entorno institucional, era mayor. Este es un gran ejemplo del alcance que tienen propuestas como la del programa CineZap, al actuar como posibilitadores del diálogo y la tolerancia, es una invitación al respeto del otro como otro y como igual, sin las barreras de género, religión, nacionalidad, entre otros, (Huergo, 2007); es propiciar el espacio para hablar y tratar temas que tal vez en otros espacios no se tiene la posibilidad de hacerlo.

Otra propuesta temática, relacionada con la reivindicación de los derechos de la clase obrera o de la clase media, es la materializada en el cortometraje: La toma realizado durante el 2017 en la escuela Técnica Número 17 Brigadier General Don Cornelio de Saavedra. La historia inicia mostrando a Martín Urquía, quien es representado por uno de los estudiantes del grupo. Este personaje es un joven periodista de clase alta que tiene una marcada idea oligarca frente al campo 
laboral y los roles cada individuo. Mientras el personaje se viste de corbata se oye una voz femenina de narrador que dice:

"Martín Urquía nació el 11 de julio de 1983 en Belgrano, Ciudad de Buenos Aires, su madre es abogada y su padre dirige una empresa inmobiliaria. Terminó sus estudios secundarios en un importante colegio bilingüe y luego estudió periodismo en una universidad privada. A Martín le gusta mucho su profesión pero no se compromete demasiado, es un poco frío y no muy solidario. Como hijo único siempre tuvo todo... y más... Creyó durante mucho tiempo que el planteo era sencillo: algunos nacían para ocupar puestos privilegiados y otros para servirlos, aunque ahora ve las cosas algo diferentes"

El primer planteamiento que propone este cortometraje, es la construcción, a partir de estereotipos, del perfil de lo que ellos consideran un "típico" personaje de clase alta. Personas que habitan en barrios de prestigio y renombre, que por tradición familiar acceden a estudios universitarios, por lo general en instituciones educativas privadas, debido a que cuentan con el recurso económico para costear las mensualidades. Individuos que suelen ocupar cargos directivos o con trabajos de prestigio, como ser el director de una empresa o ser un abogado. Se refuerza la idea de que un alto poder adquisitivo parece despojar a los individuos de sensibilidad frente al otro y le otorga un carácter individualista y egoísta a las personas de esta clase social.

La historia continúa con Martín, quien debe hacer la cobertura de una fábrica que fue tomada por obreros, hecho que le incomoda, ya que afirma que "los obreros son violentos y agresivos". Durante la grabación de la noticia, se recrea una escena de represión policial, donde los obreros junto con el periodista son forzados a resguardarse dentro de la fábrica. Una vez adentro los obreros se muestran amables y solidarios con el periodista, y le exponen los motivos por los cuales han realizado la huelga y el reclamo por sus derechos laborales. Posteriormente se enteran por el noticiero que el periodista fue secuestrado por los obreros. Martín, después de haber compartido y escuchado a los obreros decide salir a hablar frente a las cámaras para aclarar que no le han 
secuestrado y reivindica los motivos por los cuales los obreros se manifiestan. Ante este acto los obreros le arengan y le aplauden.

Frente al desarrollo narrativo que los jóvenes de esta escuela plantean, además del marcado perfil de diferenciar las clases sociales, visibilizan también la recreación de una realidad que les inquieta, la de las manifestaciones, huelgas y reclamos por los derechos laborales, posiblemente porque familiares o allegados hayan vivido situaciones similares, o por el acceso a información de estos acontecimientos en medios de comunicación como la televisión. De igual manera, muestran el acto de la represión policial como una de las respuestas más recurrentes que se ven frente a las protestas o manifestaciones. Estas construcciones hablan de la realidad que les rodea, de la que hacen parte y frente a la cual desean expresarse, desean plasmar una mirada y una postura política al respecto.

El final del cortometraje pretende revelar la reivindicación del personaje principal, mostrándole sensible y solidario. Deja entrever además de una mirada optimista, un deseo o un anhelo, que tiene que ver con los estigmas y los estereotipos. El mensaje final invita a romper con aquellos imaginarios colectivos, que posicionan a las clases bajas y la clase obrera con individuos violentos e iletrados y les posiciona en igualdad de condiciones y de derechos frente al resto de la sociedad.

Si bien no existe una generalidad en cuanto a cuáles son los temas más recurrentes en las historias de los cortometrajes de estas escuelas, lo que sí es evidente es que toda narración habla de la cultura y la cotidianeidad de cada uno de los grupos. Los jóvenes construyen historias de ficción basadas en sus experiencias y en su visión del mundo, mezcladas con estructuras y formas narrativas que han apropiado de la televisión y del cine, las historias son básicamente adaptaciones de estructuras narrativas ya aprendidas, llevadas a sus experiencias cotidianas:

"La cultura local de los jóvenes aflora, principalmente, en la elección de los personajes y sus entornos, en tanto que la estructuración y resolución de los conflictos obedece, más bien, a las normas narrativas dominantes en los medios. En este proceso se dan 
situaciones de acercamiento y otras de alejamiento y reconversión.” (Luna, 2012, p.210)

\subsection{Escena 8 - Ext - día - Los participantes, jóvenes y escuelas}

Uno de los elementos más relevantes que completan la ecuación del programa CineZap son los estudiantes y las escuelas que participan. Como ya lo mencionaba, las actividades se desarrollan en escuelas medias del sur de la Ciudad de Buenos Aires, si bien no es pertinente generalizar, si puedo mencionar algunas características en común que comparten las dos escuelas en las que participé, "las escuelas se sitúan en espacios sociales de alta complejidad caracterizados por una marcada brecha entre las demandas y requerimientos comunitarios y las respuestas que a través de sus instituciones la sociedad les ofrece" (Luna, 2012, p.205)

Debido a las condiciones sociales y económicas de las zonas en las que se ubican estas escuelas, muchos de los jóvenes deben convivir con situaciones complejas, que indiscutiblemente permean el ámbito escolar. Los jóvenes asisten a las clases y llevan consigo sus experiencias, sus inquietudes y sus problemas, que están en el devenir entre los conflictos propios de la adolescencia y los matices de su contexto familiar y local, "gran parte del alumnado de nuestras escuelas, además de vivir en situación de pobreza, se vincula con problemáticas sociales como la violencia, el embarazo temprano o el consumo de sustancias adictivas. En los casos más extremos, los jóvenes o sus familias tienen causas con la justicia por hechos delictivos” (Luna, 2012, p.205)

En el caso de la Escuela de Educación Media No 6 Distrito Escolar 5, está ubicada en el barrio Barracas, en Montesquieu y Avda. Iriarte (3400) y según datos obtenidos de su sitio web oficial www.cinezap.com.ar, la escuela inició su funcionamiento en el año 2009 en un edificio propio y tiene dos turnos, a la mañana de 7:45 a 12:20 hs y a la tarde de 13 a 18 hs. Atiende a jóvenes de los barrios Barracas-Zavaleta, principalmente a los residentes de la villa 21-24. Las villas se consideran 
asentamientos, conjuntos de viviendas que se han construido poco a poco en terrenos sin dueño o en terrenos tomados.

De manera paulatina, familias se han instalado en estos espacios y han construido sus casas muchas veces de manera precaria y sin los requerimientos de construcción reglamentarios, inicialmente no cuentan con los servicios públicos como agua, electricidad o gas, pero con el pasar del tiempo los habitantes han ideado maneras para hacer llegar estos servicios hasta sus hogares, en algunos casos de manera clandestina o ilegal y en otros casos gracias a intervenciones y peticiones de organizaciones barriales, el Gobierno de la Ciudad les ha suministrado la infraestructura necesaria para acceder a estos servicios.

Además de las distintas necesidades que demanda la expansión y consolidación de estos barrios, la escuela resulta ser una de las peticiones de los habitantes de la zona, ya que los niños al concluir sus estudios primarios se enfrentaban a la falta de una escuela media o secundaria de fácil acceso. Si los jóvenes deseaban continuar con sus estudios debía enfrentarse a la escasez de matrículas y/o a tener que desplazarse a otros barrios o a otras zonas de la ciudad para acceder a escuelas secundarias. Como lo ratifica la información publicada en su sitio web, debido a las peticiones de la comunidad y al trabajo colectivo entre organizaciones como el Padre Pepe, el CFP No 9, el Club de Jóvenes, Radio Gráfica, Centro Cultural Fraternidad del Sur, la Escuela Primaria No 12 DE 5, CESAC N 35, entre otros, en el 2009 se concluyó la construcción de esta escuela.

Los jóvenes que asisten a esta institución tienen unas edades promedio de 12 a 20 años aproximadamente, en este amplio rango de edades hay gran diversidad de aspectos que los caracterizan. Durante el 2016, estuve acompañando al grupo de 5to año en las actividades del programa CineZap. En ese tiempo pude identificar algunos rasgos como las identidades nacionales individuales y familiares, sus composiciones familiares, sus actividades externas a la escuela, particularmente laborales, sus relaciones interpersonales con sus compañeros y docentes y algunas de sus opiniones y perspectivas frente a la escuela y al programa CineZap; aspectos que analizaré a profundidad en los próximos capítulos. 
La escuela Técnica Número 17 Brigadier General Don Cornelio de Saavedra, es la otra escuela en donde desarrollé mi trabajo de campo, allí tuve mis primeros acercamientos al programa CineZap y acompañé el proceso durante el 2015. Está ubicada en la localidad de Parque Avellaneda, sobre la calle Lacarra y a pocos metros de la Av. Directorio.

En mis primeros días en esta escuela, el docente de cine me comentaba que la mayoría de los estudiantes son de la zona, es decir, viven en las calles y barrios aledaños a la escuela; pero existen algunos casos en los que los jóvenes no viven cerca pero asisten ya que sus padres les inscribieron allí, debido a la reputación de las escuelas con modalidad técnica, bajo el criterio que al culminar sus estudios secundarios en este tipo de instituciones se les facilita la posterior inserción laboral.

Esta escuela técnica ofrece a sus estudiantes elegir una especialidad entre las siguientes: construcciones, electricidad, electromecánica y electrónica. De esta manera cada joven cursa materias acordes a su especialidad y algunas materias se cursan de manera obligatoria para todos los jóvenes, las que se corresponden al secundario básico común; así cuando los jóvenes terminan de cursar su secundario reciben un título que avala sus conocimientos básicos con relación al campo de su elección y les habilita para trabajar en el rubro.

La institución cuenta en sus instalaciones con aulas, talleres, herramientas, docentes e instructores para que los estudiantes puedan hacer prácticas de la especialidad elegida. El ingreso a esta escuela debe hacerse desde el primer año del secundario para que puedan cursar la totalidad de las materias y así obtener el título correspondiente.

Algunos de los aspectos que hallé en mi acompañamiento en esta escuela tienen que ver con el lugar de origen de los estudiantes y familiares, las proyecciones a futuro de los jóvenes, las relaciones interpersonales y de poder entre estudiantes y docentes, entre otros aspectos que desarrollaré en los capítulos siguientes. 


\section{CAPÍTULO 2: La escuela técnica, una identidad tomada dentro del universo de la construcción civil}

En este capítulo, profundizo en el trabajo de campo desarrollado en la escuela Técnica Número 17 Brigadier General Don Cornelio de Saavedra. Mi acompañamiento a las clases de cine en esta institución se dió entre los meses de mayo y noviembre del año 2015. A continuación analizo todo el proceso por el cual pasó este grupo de jóvenes al participar de las clases de CineZap, desde los primeros encuentros donde crearon la historia para el video que debían realizar, hasta la puesta en marcha de la grabación y la posterior edición y finalización del cortometraje.

Enfatizo en algunos aspectos como las decisiones y preparativos propios de cada una de las etapas: en la preproducción, la creación de la historia, del guión y la preparación de las jornadas de grabación. En la producción todas las anécdotas y vivencias que se dieron alrededor del proceso de grabar las escenas y en la etapa de posproducción, la manera en que vieron concluido y materializado todo el trabajo realizado durante el año.

Recreo los debates, discusiones y decisiones que se dan durante los diferentes encuentros de las clases de cine. Allí sobresalen aspectos propios del contexto socioeconómico de este grupo de jóvenes y docentes, situaciones de su cotidianidad y percepciones que tienen de su entorno, elementos que de una u otra manera influyen y contribuyen al proceso de creación del cortometraje que realizaron.

Mi intención es resaltar el carácter etnográfico de esta investigación, relatando con detalle las acciones, momentos, diálogos y comentarios que observé durante mi participación en este proceso. Y posteriormente, con base en autores y textos que conforman el campo comunicación/educación, construir relaciones teóricas con las cuales comprender la manera en que los jóvenes, consciente o inconscientemente, plasmaron sus realidades a través de la construcción de historias de ficción; crearon personajes con los cuales se identificaban o identificaban a las personas que les rodean, crearon situaciones similares a las que viven cotidianamente y entretejieron una trama que comprende referentes audiovisuales, como películas o programas de televisión y lo mezclaron con experiencias y anécdotas propias. 
Busco generar un entramado entre lo observado durante mi acompañamiento a este grupo de jóvenes y las reflexiones teóricas de algunos de los autores del campo, como Jorge Huergo, Paulo Freire, Jesús Martín Barbero, Guillermina Tiramonti, entre otros, incluyendo las reflexiones y comentarios recopilados de entrevistas, textos y ponencias producidos por docentes, coordinadores y ex-docentes del programa CineZap.

\subsection{Escena 9 - Int - día - La escuela Técnica y los estudiantes de sexto año}

Mi primera inmersión a las prácticas de CineZap se dió con los estudiantes de sexto año, turno tarde, de la escuela Técnica Número 17 Brigadier General Don Cornelio de Saavedra durante el año 2015. Este grupo estaba compuesto por 35 jóvenes, 34 eran varones y había tan sólo una mujer en el grupo. Se caracterizaba porque todos eligieron la modalidad de construcciones civiles para su especialidad técnica. Las clases de CineZap estaban a cargo del docente Fernando Morabes, quien llevaba más de 5 años trabajando en el programa y las clases de cine se vincularon con la materia de lengua y literatura que estaba a cargo de la docente Mariana Leiva. Se había pactado que las clases de cine se desarrollaran los días jueves en la tarde, en el horario de la clase de lengua y literatura.

Fernando es un hombre de 45 años aproximadamente, es licenciado en Comunicación Social de la Universidad Nacional de La Plata (UNLP), también es docente de la cátedra de Producción Audiovisual en la Facultad de Periodismo y Comunicación Social de la UNLP. Fernando vino a ser uno de mis primeros contactos para acceder al programa CineZap, ya que mientras cursaba mi maestría en la UNLP, una de las docentes, la actual directora de la maestría, me comentó acerca de la existencia de este programa, ya que Fernando, que trabaja con ella en la facultad, lleva varios años vinculado a CineZap, si bien inicialmente me contacté directamente con los coordinadores del programa, Marcos Sacchetti y Cristian Gauna, es con Fernando con quién accedí a esta escuela.

Fernando es un hombre sobrio, alto y de cabello oscuro y ondulado, usualmente viste de manera casual: jeans y camisa o remeras; es un amante del mate, siempre lleva consigo el set matero: termo, mate, bombilla y yerba. Tiene voz gruesa y habla de manera pausada. Al momento de iniciar mi 
trabajo de campo, a mediados del 2015, él se desempeñaba como docente de cine en la escuela Técnica Número 17 Brigadier General Don Cornelio de Saavedra, en donde ha desarrollado las actividades del programa CineZap por tres años consecutivos.

Mariana Leiva es la docente de lengua y literatura, es una mujer de 35 años aproximadamente, de cabello castaño y largo, tez blanca y lleva braquets en los dientes; es de nacionalidad paraguaya, aunque su acento es marcadamente porteño, por pequeños momentos solía decir palabras o tomar acento paraguayo. En una de las conversaciones con Fernando me comentaba que Mariana inicialmente había ingresado a la escuela como suplente, pero ante la reiterada ausencia de la docente titular por inconvenientes médicos, de carácter psiquiátrico, Mariana había llevado la materia por tres años consecutivos, el mismo tiempo que Fernando había acompañado las clases de cine en esta institución. Fernando comentaba que ella muestra gran interés en las clases de cine ya que hizo cursos de escritura de guión para cine y tenía algunos conocimientos de realización audiovisual.

Mi acercamiento a este grupo se da un mes y medio aproximadamente después de iniciadas las clases de CineZap en esta escuela, para cuando yo me sumé, en el mes de mayo, los docentes Fernando y Mariana, ya habían avanzado en algunos aspectos, por ejemplo, Fernando ya les había explicado la dinámica y etapas de realización audiovisual (preproducción, producción y postproducción) y ya se habían hecho avances con respecto a la elección del tema a tratar en el cortometraje.

El primer día que llegué a la escuela me encontré con un edificio bastante grande, que ocupa casi media manzana. Al ingresar se encontraba el portero, un hombre de 40 años aproximadamente, quien al vernos entrar nos saludó, se ve que ya conocía a Fernando y le saludó cordialmente. Este hombre estaba atento a la llegada de los jóvenes y de los docentes. Al entrar lo primero que ví es un gran salón de eventos o conferencias, por el pasillo derecho estaban las oficinas administrativas y por la puerta de la izquierda se accedía a las aulas, justo al costado de esta puerta había un gran mural con trofeos y menciones de la escuela. En el sector de las aulas había un gran patio, en la planta baja y en el primer piso había una serie de pasillos con salones que le rodeaban. 
Las clases de CineZap se alternaban entre el aula designada para este grupo y el aula de audiovisuales, un salón ubicado en el primer piso al lado de la biblioteca, que estaba adecuado con un video proyector, reproductores de DVD y amplificadores para el sonido. Había unas pequeñas ventanas en lo alto de una de las paredes que habían sido tapadas con telas negras para oscurecer el salón.

Junto a los 35 jóvenes y los docentes Fernando y Mariana, también participaban dos voluntarios de la Universidad del Cine. Como comentaba anteriormente, el convenio que tiene el programa con esta universidad permitía que los estudiantes de las carreras de cine hicieran sus prácticas pedagógicas con los grupos que participaban de CineZap, en esta ocasión se vincularon un joven de nacionalidad chilena y otro de nacionalidad boliviana, ambos de aproximadamente 25 años, a ellos se les presentaron como pasantes o practicantes y a mí se me presentó también como colaboradora, aclarando que mi participación sería con fines de llevar a cabo esta investigación.

\subsection{Escena 10 - Int - día - "Identidad robada", del cuento al guión}

En el momento en que tanto los practicantes como yo, nos vinculamos a las actividades de este grupo, ya los docentes Mariana y Fernando habían avanzado con la elección del tema. Mariana en su materia de lengua y literatura, que se dictaba dos veces por semana, dedicaba uno de esos días a CineZap y el otro avanzaba en sus temas del currículo.

Durante estas clases les había pedido que leyeran algunos textos de autores argentinos, para esa ocasión todo el grupo había leído el cuento Casa Tomada de Julio Cortázar. Este texto narra la historia de dos hermanos que viven en una casa muy amplia, tienen una rutina establecida y viven de los ingresos del negocio familiar. La mujer tiene gran habilidad con el tejido, y entre los dos se encargan del cuidado y limpieza del lugar, el personaje principal empieza a notar algunos ruidos o murmullos en algunos sectores de la casa, cuando esto sucede cierra con llave las puertas de ese sector, se presume un temor a algo que parece invadir o adueñarse de la casa, poco a poco estos murmullos se van apoderando de cada uno de los espacios del lugar, llevándolos a abandonar la casa. 
A partir de este cuento, a cada uno de los estudiantes se les pidió realizar una adaptación libre, es decir, elegir un personaje, un lugar o una acción de la narración y crear un nuevo cuento. Posteriormente cada joven leyó para el grupo su escrito y por votación se eligió uno de los textos, para esa ocasión el cuento elegido fue escrito por un joven de apellido Yucra, tenía por título: Identidad tomada y narraba la siguiente historia:

“Transcurre el año 2001 y Alfredo Matías Pinta Paredes espera a que sea el fin de su jornada laboral para regresar a casa, al llegar a su casa se recuesta en un sofá y empieza a leer un libro, de repente cree ver una sombra y se sobresalta, intenta seguir con la lectura pero está nervioso y se levanta a mirar por la ventana pero no encuentra nada extraño, inesperadamente escucha unos ruidos que provienen del sótano, pregunta quien anda ahí, pero al no obtener respuesta corre asustado a su habitación, desesperado decide llamar a su amigo Roberto quien llega quince minutos después, le cuenta lo sucedido y deciden bajar al sótano.

Roberto baja primero, la puerta está entreabierta y ve a tres hombres discutiendo, les escucha hablar sobre Alfredo, sobre su profesión como arquitecto y su reputación en el campo laboral. Exaltado, Roberto le dice a su amigo que corre peligro y que debe salir de la casa porque hay tres hombres que quieren robarle su identidad y su dinero. En eso los ladrones los escuchan, salen y les arrinconan, asustado Alfredo les pregunta qué quieren de él y los asaltantes le dicen que quieren su vida. Mientras tanto Roberto aprovecha la confusión y sale corriendo sin que le vean, al salir de la casa escucha unos disparos y corre asustado hacia la comisaría, estando allí le relata exaltado los hechos al oficial, este le toma la declaración y al finalizar le pregunta su nombre, éste duda y finalmente responde que su nombre es Alfredo Matías Pinta Paredes."

Esta narración toma como punto de partida la idea de apoderarse de algo que le pertenece a otro, se asocia el robo, no sólo con lo material sino con adueñarse de cosas intangibles, en este caso la identidad, la vida y la reputación del arquitecto. Durante las reflexiones y discusiones de la historia en el proceso de escritura del guión, los estudiantes y docentes analizaron la sucesión de acciones, los personajes y el desenlace. Durante los primeros encuentros posteriores a la elección de este 
texto, empezaron por definir a los personajes; en discusiones colectivas, se les invitó a los jóvenes a imaginarse y a proponer el perfil físico, psicológico y social de los personajes.

La clase siguiente a la elección de este cuento, nos encontrábamos en el aula de sexto año, un salón con aproximadamente 15 escritorios, las mesas eran de madera y tenían el tamaño para ubicar a dos estudiantes, detrás de cada mesa había dos sillas sencillas, de caño y madera. Los escritorios formaban dos filas dirigidas hacia el tablero, al fondo del salón había una ventana larga y alta con vidrio esmerilado, que permitía la entrada de luz, pero no dejaba ver con claridad el exterior.

La docente Mariana estaba sentada en su escritorio cerca del tablero, de frente a los estudiantes, tenía sobre la mesa una carpeta con el listado de estudiantes, al iniciar la clase la abrió y les llamó a cada uno por su apellido, los jóvenes respondían con la palabra "acá" o "yo", algunos levantaban la mano, otros solamente contestaban; ella marcaba con bolígrafo frente a cada nombre si se encontraba presente o no. Fernando estaba de pie cerca del escritorio mirando a los jóvenes, yo me ubiqué al fondo del salón y me senté frente a un escritorio que estaba libre.

Mariana terminó el llamado de lista y les recordó que íbamos a continuar con la creación del guión para el cortometraje y le cedió la palabra a Fernando, éste les reiteró la importancia de la escritura del guión y de la creación de los personajes. Entonces les preguntó: “Bueno, a ver, ¿pensemos cómo serían el arquitecto y su amigo? ¿cómo es este amigo? o ¿por qué razón es él a quien decide llamar cuando escucha estos ruidos en la casa?", hubo silencio, ninguno se animaba a responder.

Fernando insistió: "Bueno, ¿ustedes por qué creen que alguien querría robarle la identidad al arquitecto?”, Mariana les animaba, “A ver, ¿que se les ocurre?”, uno de los jóvenes respondió: “pues porque tiene más plata”, un par de chicos del lado asintieron. Fernando comentó: “muy bien, esto puede ser un buen motivo, porque el arquitecto gana más plata, si es así ¿en qué trabajaría el amigo? ¿qué profesión tiene? ¿una en la que gane menos?” Luego Mariana les dijo: “tiene que ser un amigo cercano, quizá trabaja con él en la construcción, así conoce todos los movimientos del arquitecto” Fernando les miraba, “¿qué piensan de esto? el amigo podría trabajar con el arquitecto?", los chicos asintieron tímidamente, algunos decían "si, si, que trabaje en la obra también”. Fernando dijo: “y si trabaja en la obra entonces ¿qué cargo tiene? ¿es un 
trabajador común?" los chicos se quedaron pensando, Mariana respondió "el maestro mayor de obra... puede ser el maestro mayor de obra ¿no?”, les incitó con la mirada a que participaran más, uno de los jóvenes, un chico que parecía ser participativo, respondió "si obvio, el maestro mayor es la mano derecha del arquitecto, es como su amigo, por eso conoce todos los planes del arquitecto ¿no?” lo demás chicos asintieron o comentaron "sí, sí, eso está bien”.

Mariana iba tomando nota en una agenda. Fernando retomó "muy bien, entonces la relación entre los personajes es que uno es el arquitecto y el maestro mayor de obra le siente cierta envidia y desearía tener su fama y dinero, eso es una buena motivación como para querer robarle la identidad a alguien...”

Es así como en este encuentro se definió que ahora el amigo sería el maestro mayor de obra de las construcciones donde trabaja el arquitecto. En este punto se evidencia la marcada presencia del contexto de los jóvenes de este grupo, debido a la modalidad escolar de su institución educativa y su elección de seguir la especialidad en construcciones civiles, crearon los personajes con base a los referentes que tenían más cercanos, los personajes y roles tradicionales del campo de la construcción.

Después de definir la relación laboral de los personajes principales, en uno de los encuentros se profundizó acerca de cómo serían física y socialmente estos personajes. El docente Fernando empezó por preguntarles cómo se los imaginaban, qué ropa podrían usar, cómo serían físicamente y cómo se expresarían, ante esta pregunta surgieron algunos comentarios: "pues el maestro mayor de obra se viste normal y el arquitecto se viste más cheto" afirmó uno de los estudiantes.

Fernando les invitó a reflexionar al respecto, les preguntó: “¿y cómo sería eso? ¿Cómo es vestirse normal? Conozco personas que consideran que vestirse normal es usar alpargatas y otras que normal es usar botas", hubo un pequeño silencio, al final uno de los jóvenes comentó: "pues normal sería usar jean, zapatillas y remera o tal vez una camisa”, Fernando continuó “¿entonces cómo sería vestirse cheto?" el mismo joven respondió “como se visten los arquitectos, ;cheto! osea con pantalones de vestir, siempre con camisa, zapatos y saco de vestir, tipo un bléiser o algo asi'", la docente Mariana les preguntó qué otro elemento agregarían a la vestimenta para acentuar 
el carácter o la especificidad de su trabajo, uno de los chicos comentó: "el arquitecto podría llevar algunos planos... y bolígrafos en el bolsillo de la camisa" otro también comentó "el maestro mayor de obra tendría que llevar el casco y usar las botas reglamentarias".

Tras este ejemplo de la manera en que los estudiantes construyeron el aspecto físico de los personajes, es identificable que las formas cognitivas de operar están basadas en el refuerzo de estereotipos, es decir, los jóvenes tienen un imaginario, preconcebido, aprendido y reforzado socialmente, acerca de cómo debería o no vestir un arquitecto o un maestro mayor de obra.

Este sistema se aplicó en la gran mayoría de decisiones que se tomaron a la hora de definir la historia. Elementos también como la casa del arquitecto, ya que, según sus comentarios, si tiene dinero y goza de reconocimiento debe tener una casa grande y ostentosa, o el maestro mayor de obra, más cercano al imaginario que tienen de un trabajador de clase media, por tanto le denominaban como "normal" haciendo referencia a estos aspectos que les resultaban más cercanos y cotidianos.

La ex docente de CineZap Luna, evidencia que este tipo de situaciones son una constante en las experiencias vividas por los diferentes grupos que participan de CineZap:

"La cultura local de los jóvenes aflora, principalmente, en la elección de los personajes y sus entornos, en tanto que la estructuración y resolución de los conflictos obedece, más bien, a las normas narrativas dominantes en los medios. En este proceso se dan situaciones de acercamiento y otras de alejamiento y reconversión.” (Luna, 212, p.210)

\subsection{Escena 11 - Int - día - Construcción de personajes - los estereotipos}

En los encuentros posteriores se siguió haciendo énfasis en la construcción del guión y se habló acerca de los roles que cada estudiante deseaba asumir. El docente Fernando, con intervenciones y comentarios de los pasantes y míos, repasó las etapas de realización audiovisual y cuáles son los cargos y responsabilidades de cada departamento. 
Durante la clase siguiente, se definieron los roles y cargos para la realización del cortometraje. Uno de los primeros roles que se designó fué el de los actores principales, un grupo de jóvenes propuso que un chico llamado Facundo fuera el arquitecto, la docente Mariana preguntó por qué debería ser él y uno de los jóvenes respondió "Si profe, que sea Facundo, él es el que mejor habla en público, además mírelo, siempre se viste medio cheto y usa esos lentes..." sonaron varias carcajadas de los estudiantes. Facundo pareció estar de acuerdo, se rió, se miró la ropa e hizo ademanes con sus manos arreglándose la camisa como insinuando que estaba bien vestido; la docente le preguntó a Facundo su opinión al respecto y él respondió "si profe yo le hago".

La docente tomó nota en su agenda y prosiguió "bueno ya está definido el arquitecto, ahora ¿Quién quiere ser el maestro mayor de obra?", se miraban entre ellos, pero nadie se animaba a dar un nombre, de repente Micaela la única chica del grupo dijo "¿y Maxi? Maxi dijo que él quería actuar", todos se voltearon a verlo, Maxi se sonrojó. Era un chico que hablaba poco en clase, pero que siempre estaba atento y realizaba las actividades que le proponían, Maxi lo dudó y dijo " ¿y por qué yo? ¿No hay otro que quiera?” Micaela lo miró, "Maxi, vos dijiste el otro día que querías actuar” algunos compañeros lo apoyaron “isi Maxi hacele boludo!”, el joven no parecía muy seguro pero aceptó moviendo la cabeza.

Mariana nuevamente tomó nota en su agenda. "Ahora hay que definir los ladrones" dijo, "y el agente de la comisaria” comentó un chico, “¿bueno quienes quieren hacer de ladrones?” preguntó la docente, una vez más se miraron, se rieron y se decían entre ellos "hacele vos" uno le respondió “no, ¿Por qué yo?, hacelo vos que tenes pinta de chorro!". Ante la negativa por parte de los estudiantes, Mariana propuso que no necesariamente se les debía ver la cara, que podrían usar unas máscaras o buscar la manera que desde la cámara no se les vieran los rostros. Finalmente, un grupo de tres amigos que siempre se sentaban juntos, accedieron a representar a los ladrones; un jóven dijo "eso profe, ellos tiene pinta de chorros", ante el comentario uno de los tres amigos lo empujó suavemente y otro le dijo un poco agresivo "¡eh qué te pasa boludo!”, Mariana y Fernando les pidieron que se hablaran con más respeto.

Mariana escribió y luego comentó, "ahora el comisario", de nuevo nadie se animaba a postularse, Mariana propuso a Cristian, un joven delgado, de baja estatura y tez morena. El chico dudó y luego 
aceptó sin decir mayor palabra, alguno comentó: "no profe, pero si tiene que hablar se le va a notar lo paraguayo”, Cristian le respondió: “eh, si no hacelo vos boludo”. Mariana les pidió que se calmaran, y tomó nota.

De estos comentarios se puede identificar un marcado rechazo por parte de los jóvenes por representar los papeles de antagonistas, específicamente de ladrones o asaltantes. En una conversación posterior, uno de los chicos que actúa de ladrón me comentaba: "yo no quiero que mi mamá vea el video que hicimos, no le va a gustar que yo sea el chorro... y mi viejo ni hablar...”. Aunque se sabe que es una representación y el video hace parte de una construcción ficticia, en este caso, los jóvenes temen ser estigmatizados o que se les relacione con ladrones, no sólo por parte de sus compañeros de la escuela, sino también por sus familiares, ya que saben que este cortometraje será presentado en actos y muestra públicas en la escuela.

Los estereotipos funcionan de manera inconsciente e inevitablemente llevan consigo juicios de valor que se manifiestan en comentarios y afirmaciones (Gamarnik, 2009). Otro motivo por el cual los estereotipos operan de manera tan recurrente es porque tenemos la certeza que es un lenguaje compartido y que con facilidad puede entenderse en cualquier ámbito, "una razón por la que los estereotipos tienen éxito es porque evitan el esfuerzo de pensar en forma compleja. Son simples, fácilmente reconocibles y significan más o menos lo mismo para todos" (Gamarnik, 2009, p.2) Para el caso de creación de los personajes es fácil recurrir a estereotipos para dar a entender un mensaje, debido al reducido tiempo narrativo del cortometraje, 10 a 15 minutos aproximadamente y garantiza que cualquier persona que lo vea entienda con rapidez la historia.

\subsection{Escena 12- Int - día - Roles, cargos y apropiación}

En el siguiente encuentro, como era costumbre, los jóvenes ya se encontraban en el aula, Fernando y yo ingresamos al salón. La profesora Mariana estaba sentada en su escritorio terminando de tomar la asistencia en la carpeta. Saludamos y Mariana les recuerdó que seguiríamos avanzando con la clase de cine. Yo me senté en la parte de atrás, en una silla que estaba vacía; Fernando se quedó al lado de Mariana, cerca del tablero. 
Fernando les explicó de nuevo los cargos y equipos de trabajo. Se empezó por hablar del guión, les propuso que conformaran un equipo junto con el autor del cuento para desarrollar el guión, pero no hubo voluntarios. Yucra, el estudiante que escribió el cuento les empujó con el codo a los dos compañeros que estaban a su lado, Mariana les preguntó si querían y estos aceptaron.

"Ahora el director" dijo Fernando, "vamos a elegir un director que será la cabeza pero también va a tener unos asistentes que le van ayudar en todo lo que tiene que ver con el guión técnico, pensar los planos y todo eso”, Mariana miró al autor del cuento y le preguntó "Yucra ¿vos no me habías dicho que querías dirigir?" tímidamente le respondió: "si profe, pero ahora me toca hacer lo del guión”, Mariana miró a Fernando y este comentó: "no hay problema con eso, podés estar en los dos cargos si eso querés, igualmente no sé si alguien más se quiere postular a director" miró a los estudiantes y nadie comentó nada, Mariana dijo "bueno si todos están de acuerdo, vos estas en la parte de guión y hacés de director también" Yucra asintió.

La siguiente elección fue del equipo de producción, un grupo que se encargaría de gestionar y conseguir desde los permisos para salir de la escuela hasta las locaciones y elementos necesarios para la grabación de la historia. Mariana comentó mirando a Fernando "el tema de los permisos ya lo estoy gestionando, sólo falta definir bien las fechas de grabación”, él le respondió "elijamos unas fechas tentativas y yo lo converso con el resto de los profes de CineZap para no cruzarnos en fechas con las otras escuelas", los jóvenes les miraban. Fernando les dijo a los estudiantes "los productores van a gestionar las locaciones, a revisar que las planillas y que el plan de grabación se ajuste a los tres días que tenemos los equipos, además ayudar a conseguir todos los elementos necesarios como cosas de utilería y demás". Micaela levantó la mano "yo quiero”, Mariana: “muy bien, ¿alguien más? No puede ser solamente ella” Micaela miró a algunos de los compañeros que estaban detrás de ella, "bueno, yo" dijo uno y seguidamente otro "y yo", Mariana anotaba.

Fernando continuó explicándoles las funciones de las demás áreas: cámara, sonido, iluminación, escenografía y vestuario, y se eligieron los grupos para cada equipo de trabajo, de tal manera que al final todos tuvieran un cargo o responsabilidad. 
Durante las clases de lengua y literatura, la docente Mariana realizó avances en la escritura del guión, con el grupo de estudiantes designados para esta labor, les mostró el formato que iban a utilizar, donde se discrimina la historia por escenas y se describen detalladamente las acciones. Básicamente el primer paso que realizaron fue tomar el cuento y pasarlo al formato de guión.

Esta dinámica, en donde se conforman equipos para desempeñar las diferentes labores necesarias para la realización de un cortometraje, había sido planteada por el equipo de CineZap e implementada en las escuelas por cada uno de los docentes de cine.

La forma de trabajo, es la misma que se usa en las producciones audiovisuales de cine y televisión. Debido a que gran parte del equipo de CineZap son realizadores audiovisuales o comunicadores sociales, ellos han tomado esta modalidad de trabajo aprendida de su experiencia en el medio y la han trasladado a la propuesta educativa de CineZap.

"CineZap propicia la experiencia de Preproducción- Producción- Posproducción respetando el sistema - casi posfordista- de la industria del cine, pero adaptándolo a nuevas condiciones de producción posible en ámbitos escolares." (Gauna, 2004, p.7)

Al parecer, esta dinámica les ha generado buenos resultados en cada una de las escuelas donde intervienen, afirmando que esto les invita a los jóvenes a empoderarse y a adoptar una mirada más crítica frente a los medios, Gauna afirma:

"El proyecto de cine es un proyecto de calidad que promueve la educación inclusiva. El mismo se articula en dos aspectos: uno que es un proyecto diseñado para promover la retención escolar, promueve las capacidades particulares y de los grupos y otro porque es su metodología promover la integración de los alumnos a partir la capacitación individual y grupal y del ejercicio continuo de las prácticas grupales.” (Gauna, 2004, p.14) 


\subsection{Escena 13 - Int - día - Relación docente-alumno}

Para un encuentro posterior a la conformación de los grupos de trabajo, por iniciativa de los pasantes y mía, le propusimos a Fernando realizar un ensayo o simulacro para que cada equipo de trabajo tuviera más claras las funciones y las responsabilidades que debía asumir durante la grabación, él estuvo de acuerdo. Al ingresar al aula, tras saludarlos y dar la explicación de la actividad del día, se conformaron los grupos de trabajo: dirección y producción se reunieron con Mariana para hablar sobre las locaciones y los elementos que iban a requerir. Cámara, sonido, iluminación y actores fueron a un aula más grande y ensayaron algunas escenas del guión, haciendo énfasis en cómo podría ir ubicada la cámara, que elementos de sonido deberían registrar y cómo podría ser la iluminación, a la vez que los actores repasaban sus acciones con ayuda de los dos pasantes.

Al grupo de guionistas les acompañé yo para ir avanzando en la escritura del guión, leímos las escenas y empezamos por revisar los personajes. Ya se había hablado del aspecto físico y de la forma de vestir de cada uno. Conforme iba leyendo, uno de los chicos no estuvo de acuerdo con los nombres de los personajes: Ricardo y Alfredo, “esos nombres... medio que no van ¿no?”, dijo; con curiosidad le pregunté por qué pensaba eso, "son muy feos esos nombres... no sé” miré a los otros chicos y les pregunté qué pensaban al respecto, hicieron cara de inconformidad y subieron los hombros. "Entonces cómo les gustaría que se llamaran” les pregunté, se quedaron en silencio unos segundos, "piensen en que los nombres nos ayuden a construir al personaje, que digan algo de él” les comenté, uno de los chicos se animó: "es que los dos nombres son muy parecidos...” yo estuve de acuerdo con ellos. Les comenté que me parece bien que los nombres fueran fácilmente diferenciables para no tener confusiones en el final de la historia, para que el espectador entendiera rápidamente el cambio de identidades; uno de los chicos dijo: "podría llamarse Máximo, el arquitecto" los demás asintieron, yo les apoyé en la decisión.

“Ahora, el maestro mayor de obra se llama Ricardo, ¿Qué opinan de ese nombre” les pregunté, entre ellos se miraron y dijeron algunas opciones de nombre alternativo, en eso Fernando que estaba con Mariana, junto con el grupo de dirección y producción, en la otra esquina del salón, nos preguntó cómo íbamos, los chicos dijeron tímidamente: “bien, bien”, yo comenté "vamos bien, ya 
tenemos nuevos nombres para los personajes”. ¿Cómo? ¿Por qué le van a cambiar los nombres?” dijo Mariana en tono desafiante "los nombres ya estaban elegidos", miró a los chicos que se giraron dándole la espalda a la profesora y uno susurró "siempre es lo mismo...".

Intentando hacer valer la decisión de los chicos, le respondí a Mariana: "estuvimos analizando los nombres y esa fue la decisión que tomamos, nosotros hacemos nuestro trabajo con el guión, ustedes después realizan el suyo desde la dirección y la producción”, hubo un silencio incómodo y Fernando dijo "bueno pero con qué argumentos cambiaron los nombres?" yo miré a los chicos y ninguno se animó a responder, yo intervine: "con los chicos hablamos que Ricardo y Alfredo son nombres que sonoramente son similares, la idea es buscar nombres que se diferencien fácilmente para que al final el espectador no se confunda y entienda el final”. Fernando miró a los chicos de mi grupo y a Mariana “bueno, es un buen motivo para cambiar los nombres”, Mariana respondió “pero los nombres tienen una razón de ser, se llaman Ricardo Paredes y Alfredo Houser porque los apellidos tienen un significado, una relación con la obra, con la construcción”, yo miré a los chicos que estaban a mi lado y les dije: “tiene razón, los apellidos nos ayudan a construir al personaje”, Fernando preguntó “pero qué nombres les pusieron?” Uno de los chicos respondió: “al arquitecto Máximo”; “pero puede ser una opción Máximo Houser y Ricardo Paredes ¿no chicos? ¿Ustedes que opinan?” les preguntó a los guionistas, quienes se encogieron de hombros y adoptaron una actitud de indiferencia. Después de esta situación seguimos trabajando en el grupo con los guionistas, les pregunté qué opinaban al respecto y uno comentó tímidamente "igual siempre son ellos los que deciden...".

Si bien ese día la discusión terminó ahí, en la versión final del guión y en el cortometraje se respetó la modificación de los nombres: los personajes pasaron a llamarse Máximo y Ricardo.

Frente esta situación quisiera reflexionar acerca de la relación docente - alumno. Tradicionalmente el lugar del docente dentro de la escuela, se le ha relacionado con el poseedor del conocimiento y del saber, y el alumno debe recibir del docente ese conocimiento, como lo analiza Mariana Nobile, en el libro Variaciones de la forma escolar. Límites y posibilidades de la escuela media, compilado por Guillermina Tiramonti, cuando afirma: "el papel del docente, su autoridad, estaba fundamentado a su vez en el saber; los profesores aparecen como aquellos detentadores 
monopólicos del saber legítimo, son ellos quienes portan aquello que debe transmitirse a quienes llegan a la escuela a aprender. Ese saber pedagógico dotaba a los educadores modernos de una identidad, una autoridad y una legitimidad propias" (Tiramonti, 2011, p.183). Si bien la autora ubica esta característica dentro de su reflexión acerca de la educación y las escuelas de la modernidad, podemos ver, que son aspectos que han permanecido en el tiempo, es la dinámica con la que funcionan en la actualidad la gran mayoría de las escuelas de Latinoamérica.

Desde el campo comunicación/educación, se reconoce que tanto los docentes como los alumnos son individuos con valores y aprendizajes previos y externos a la escuela, se identifica en cada uno un recorrido particular y se le da igualdad de condiciones en la relación de aprendizaje (Huergo, 2003). Si bien, el lugar del docente sigue siendo el de liderar los procesos de aprendizaje, desde el programa CineZap se busca que los jóvenes se empoderen y sean ellos quienes propongan y cuenten sus historias; con respecto a esta relación docente-alumno, Luna dice:

"Los docentes, lejos de estigmatizar a los alumnos, asumen un compromiso ideológico en donde lo que se prioriza son los vínculos y las relaciones humanas. Por ello se abandona el objetivo de cubrir los contenidos conceptuales prescriptos en el currículum oficial para encausar un proyecto común encaminado a sostener e impulsar a los alumnos como personas maduras capaces de moverse en su entorno social. En el tránsito los vínculos se fortalecen.” (Luna, 2012, p.211)

Aunque para los docentes de cine y coordinadores de CineZap la intención de empoderar a los jóvenes, se estimula constantemente en las clases de cine, en algunos casos, como el visto anteriormente, parece existir resistencia ante la idea de desestructurar o replantear esta relación de poder entre el docente y el alumno. En algunas ocasiones pareciera ser porque el docente se reivindica en su rol de autoridad y en otros casos porque a los jóvenes les resulta más cómodo o simplemente han asumido que su rol es el de receptores de conocimientos. 


\subsection{Escena 14 - Int - día - La historia: el universo de la construcción civil y la identidad nacional}

Tras varios encuentros en los cuales cada grupo analizó y asumió responsabilidades para concretar la grabación del cortometraje, uno de los aspectos que mayor trabajo representó durante esta etapa de preproducción fue el guión. La docente Mariana, creó un archivo compartido en internet para que todos pudieran acceder al archivo y básicamente para que pudieran trabajar en línea en cada clase y se guardaran allí los cambios realizados; se agregaron escenas, acciones y diálogos siempre tratando de conservar la esencia del cuento original.

Pocos días antes de la grabación se realizó una revisión de la última versión del guión, esta es la historia final:

"El cortometraje inicia con Ricardo Paredes, un hombre de 25 años, tez blanca y cabello oscuro entrando a una comisaría, en el lugar un policía le atiende. Ricardo le comenta que quiere hacer una denuncia, el policía toma nota y Ricardo le cuenta que él se encontraba en la casa cuando escuchó ruidos en el sótano, bajó a investigar y vio a dos o tres hombres hablando sobre dinero, escuchó unos tiros y un hombre cayó herido. En la confusión logra escapar mientras ve a lo lejos salir fuego de la casa. Posterior a esta primera escena, en flash back, es decir en un salto al pasado narrativo, está Máximo Houser, un hombre de 30 años, viste jean y camisa y lleva bolígrafos en el bolsillo de la camisa, está en un depósito donde hay planos, hojas y materiales de construcción, hay algunos albañiles que calientan agua en una pava y toman mate. Máximo habla por celular sobre los materiales, quiere que sean los más baratos, no importa la calidad, los trabajadores se miran entre sí decepcionados, uno de ellos le insulta susurrando una frase en guaraní.

Después de esto Máximo llega a su casa, un lugar amplio y elegante. Tan pronto entra escucha un ruido extraño, observa pero no ve nada particular, suenan más ruidos y éste busca nervioso por la casa mientras atiende el celular y habla con Ricardo, le dice que allí le espera para darle el dinero de los materiales y corta el teléfono. Después de unos minutos suena el timbre y Máximo abre la puerta, es Ricardo, le hace entrar y le cuenta que ha escuchado ruidos extraños, Ricardo le pregunta por el dinero y este le dice que lo tiene escondido en el horno. 
Ricardo y Máximo se acercan al sótano y en eso, tres hombres suben las escaleras y les confrontan, le apuntan con un arma a Máximo quien se resiste, forcejean y Máximo es herido de bala. Ricardo en la confusión aprovecha y escapa, corre asustado y se oculta en una esquina, ve salir a los asaltantes con bolsas y objetos de valor como cuadros, espera unos minutos y regresa a la casa. Encuentra a Máximo muerto, se acerca, le toca los bolsillos y saca la billetera y su DNI, también le quita los zapatos, va hacia la cocina, despega la foto del documento y pega una foto suya, saca unos fajos de dólares y los guarda en una bolsa, regresa hacia donde está el cuerpo, busca un bidón de gasolina, moja el cuerpo con combustible, enciende fuego y sale.

Luego vemos a Ricardo en la comisaría, es la misma escena del principio, el comisario termina de leerle la declaración y le pide su nombre para que quede en el archivo, este le responde: Mi nombre es Máximo Houser."

Con este final cerraba el relato, pocos días antes de la grabación, en las diferentes conversaciones con los estudiantes y los docentes acerca de la historia, en un momento se planteó una discusión acerca del final y de cuál era el mensaje que querían transmitir con su cortometraje. Ante eso Micaela comentó: "este final es medio raro, porque como que se sale con la suya, ¿no?”; los jóvenes y docentes discutieron acerca de si es éticamente correcto que una acción de vandalismo, robo y asesinato como la planteada, no tenga un final más esperanzador, se comentaron algunas propuestas y decidieron que el final debe comunicar el mensaje: "el crimen nunca paga".

Es así como se agregan las siguientes escenas al final de la historia: "Después de salir de la comisaría, Ricardo está en su casa, busca su pasaporte y un boleto con destino a Paraguay, le vemos en migraciones cuando le sellan la entrada al país. Posteriormente está en un restaurante hablando con una chica y le cuenta que su vida no ha sido fácil, que tuvo que viajar allí por lo sucedido en casa de su jefe, cuando va a pagar la cuenta llegan unos oficiales de policía y preguntan por Máximo Houser, él dice ser Máximo y le arrestan por fraude en las construcciones de algunos edificios y se lo llevan esposado." 
Esta última escena, con la mujer en el restaurante, se agregó por petición de Micaela, la única chica en el grupo, quien afirmaba que había sólo hombres en la historia, que quería que saliera una mujer, así que ella se postuló para ser la acompañante del protagonista en esta última escena.

Hay varios aspectos que quisiera resaltar de la historia final, uno de ellos es el hecho de que, al iniciar la narración, dentro los trabajadores de la obra hay un par que se identifican como paraguayos e incluso uno de ellos le dice una frase en guaraní, la lengua de las comunidades originarias de este país. Esta frase es realmente en ésta lengua, fue propuesta por uno de los estudiantes que era paraguayo y a la vez, tanto la docente Mariana como algunos de sus compañeros sabían el significado de esta frase porque dominan la lengua. De aquí se desprenden dos aspectos: uno el hecho de relacionar a algunos obreros con la nacionalidad paraguaya; y dos, el que algunos de los estudiantes hayan nacido o tengan familiares en este país.

Los estudiantes daban por hecho que hubiera trabajadores paraguayos en la obra, ya que, según me comentaban, conocían casos cercanos, de familiares y conocidos dentro de las obras y del rubro de la construcción. De la etnografía realizada por Patricia Vargas: Bolivianos, Paraguayos y Argentinos en la obra, ella resalta que si bien las nacionalidades per se no son la única razón que justifica la presencia de paraguayos o bolivianos en el campo de la construcción, si es posible concluir, que las relaciones interpersonales y el sistema de parentesco y recomendación hacen que sea significativo el número de inmigrantes de estas nacionalidades dentro del rubro (Vargas, 2005).

En segundo lugar, en este grupo de 35 jóvenes, aproximadamente la mitad o nacieron en Paraguay o sus padres o familiares cercanos eran de este país. Esta situación me cuestionó acerca de cuál es el perfil de los niños y jóvenes que asisten a las escuelas públicas de la zona sur de la ciudad de Buenos Aires. Según este caso, en su gran mayoría son inmigrantes o descendientes de inmigrantes de países limítrofes como Paraguay, Bolivia y Perú; cuyas condiciones socioeconómicas les llevan a instalarse en estas zonas de la ciudad, bien sea porque encuentran casas o departamentos a precios accesibles o porque familiares o conocidos residen en estas zonas y pueden acceder a viviendas por recomendación. 
Otro aspecto a resaltar con relación a los países de origen de los estudiantes, es la forma en que se identifican y/o reivindican su nacionalidad y su relación con la categoría de inmigrantes. Cuando realizaba las entrevistas a los jóvenes de este grupo, siempre les preguntaba por sus núcleos familiares y por dónde habían nacido, algunos afirmaban haber nacido en Paraguay, Bolivia o Perú y haber llegado desde muy pequeños al país; otros afirmaban ser argentinos, pero cuando les preguntaba por sus padres comentaban que ellos eran inmigrantes, es decir, se reivindican en el derecho a la nacionalidad por haber nacido en territorio argentino, pero no hablan sobre las nacionalidades de sus padres y familiares cuando son de países limítrofes a menos que se les pregunte.

Vargas en su etnografía, también registra una situación similar en el ámbito de la obra donde desarrolla su investigación y reflexiona al respecto:

"La etnicidad -y la adscripción nacional como una de sus formas de expresiónconstituye una marca de identidad potencial que puede ser tomada y movilizada cuando resulta conveniente a los propósitos de un encuentro particular (Wallman, 1979). La nacionalidad, objetivada en la letra formal de las documentaciones personales, puede entonces, ser ocultada, tergiversada o transformada en función del contexto (Goffman, 1959; Barth, 1969)”. (Vargas, 2005, p.81)

Este ejemplo, sin intención de generalizar o afirmar que siempre sea de esta manera, sirve de referencia para construir un perfil de los jóvenes que asisten a esta escuela pública y de alguna manera da luces del porqué, en muchos casos, los jóvenes de esta zona optan por asistir a una escuela técnica, y a su vez deciden especializarse en construcciones civiles, ya que afirman que esta elección y los contactos de familiares y amigos les ayudarían a abrirse paso más fácilmente en el ámbito laboral. 


\subsection{Escena 15 - Int - día - La grabación: materialización de las ideas, empoderamiento de los jóvenes}

Por disponibilidad de los equipos técnicos y de los permisos gestionados por la docente Mariana, se definió realizar la grabación del cortometraje los días jueves 8 , viernes 9 y sábado 10 de octubre.

El primer día de grabación nos citamos el grupo de jóvenes y docentes en la entrada de la escuela a las 8:45 am. Los chicos fueron llegando de a pocos y a eso de las 9:30 am ya nos encontrábamos todos en la puerta del edificio. De allí nos desplazamos unas dos calles hacia la plaza conocida como: Parque Avellaneda, allí estuvimos todo el día grabando las escenas de la casa del arquitecto y algunas tomas de los exteriores.

Al llegar a la plaza Fernando y Mariana hicieron que todos nos acercáramos en círculo para escucharles, Mariana les dio algunas indicaciones acerca de no alejarse del grupo y Fernando fue muy enfático en que todos debían estar atentos a los objetos personales, mochilas, bolsos y equipos. Les recordó qué escenas grabaríamos inicialmente y les pidió que empezaran a preparar los equipos y los actores a ponerse la ropa acordada.

Los otros dos pasantes de la FUC y yo nos acercamos a los chicos para ayudarles a preparar los equipos. Los chicos encargados de la cámara prepararon el trípode y empezaron a ver cómo encender y manipular adecuadamente la cámara, con ellos estaba uno de los pasantes.

Con el equipo encargado de sonido e iluminación estaba el otro pasante, quien les ayudaba a preparar la grabadora de audio y el micrófono, al igual que las telas reflectoras de luz. Mariana estuvo junto con los actores ayudándoles con la ropa y utilería. Fernando se acercaba a cada uno de los grupos para hablarles y supervisar que los equipos estuvieran funcionando correctamente.

Por mi parte, estuve cerca de Yucra, el director del cortometraje, era un chico tímido y no hablaba mucho, le pregunté si tenía claro qué escena íbamos a empezar a grabar, pero dudaba y miraba los papeles con el guión que tenía en las manos. Me acerqué más y entre los dos ubicamos la escena a 
grabar. Lo primero en grabarse fue en el exterior de una casa antigua ubicada en el centro de la plaza, que es usada a modo de museo.

Empezar el proceso de grabación tomó mucho tiempo, y cerca del mediodía se grabó la primera escena. Inicialmente Yucra no sabía muy bien que debía hacer, le insistí en que debía ser él quien diera las indicaciones de cuándo empezar a grabar, cuando iniciar la acción y cuando cortar. Las primeras tomas, Yucra se mostró muy inseguro, el camarógrafo empezaba a grabar por su cuenta o el actor principal era quien por lo general daba la voz de "acción" o "corte". Ante mi insistencia de que Yucra, en su rol de director debía ser quien diera las indicaciones, el joven poco a poco empezó a hablar con más fuerza y los demás esperaban a que Yucra les indicara para poder grabar o cortar.

Cerca de las 2 de la tarde, paramos para comer, un par de docentes de la escuela ayudaron a Mariana a traer las cajas con las viandas provistas por la escuela: sándwiches, jugos, aguas y frutas. Mariana y Fernando anunciaron que íbamos a para a comer, todos se sentaron en el pasto mientras un par de chicos repartían las viandas. Empezaron a comer y a conversar, se hacían chistes entre ellos y todos parecían de muy buen humor.

La propuesta de trabajo que emplean las clases de CineZap, evidencian una alternativa a las dinámicas tradicionales de aprendizaje aplicadas por la escuela. El hecho de salir del aula, realizar actividades diferentes a ver o escuchar al profesor, y poner en práctica habilidades relacionadas con la realización audiovisual, representan para los jóvenes la exploración de otras formas de aprendizaje. Al respecto Gauna afirma:

"Al mismo tiempo estas modificaciones generan una dinámica de trabajo que extiende los límites temporales y territoriales que normalmente limitan la tarea escolar, por lo que se evidencia una ruptura del espacio áulico y una reconfiguración de la disposición de los tiempos: en situación de rodaje el grupo entero decide cuál será su plan de rodaje, y las locaciones en las que se filmará. Esos días no hay hora cátedra ni recreo, toda la jornada es dedicada al proyecto y todos participan según sus roles y responsabilidades." (Gauna, 2014, p.6) 
En este punto las prácticas de las clases de cine han tomado otra dimensión. Si bien las primeras clases se abordaban ejes temáticos relacionados con el audiovisual, que por lo general no son incluidos en los currículos de las materias comunes de un secundario, y de por sí representan una novedad para los jóvenes, el hecho de salir del aula, manipular equipos técnicos como cámaras y micrófonos, actuar, cambiarse de vestuario y recrear una ficción, genera en los jóvenes otro tipo de motivación y empoderamiento frente a los procesos de aprendizaje.

Conversando posteriormente con algunos chicos me comentaban:

"La verdad es que hemos trabajado re bien, con los compañeros todo de 10, es más creo que con esto nos juntamos más.” (Micaela Cardozo, estudiante)

"Lo que más me ha gustado es el compañerismo, que todos hemos trabajado y nos reímos... no es que sea de risa, pero es un trabajo muy divertido" (Camil Bejarano, estudiante)

Después de comer las viandas retomamos la grabación, los chicos tenían mucho más clara la dinámica de grabación y las tomas se fueron grabando con rapidez. A eso de las 4 de la tarde notamos que un par de mujeres de unos 40 años aprox, se acercaban al grupo, eran las madres de dos de los chicos, saludaron a sus hijos y a los docentes. Las mujeres se quedaron un rato observando la grabación, hablaban entre ellas o les preguntaban cosas a los chicos, se mostraban asombradas y contentas con la actividad.

Claramente este tipo de actividades no sólo representan una novedad para los jóvenes, también lo es para los padres e incluso para los vecinos del barrio. Desde que se empezó la actividad en horas de la mañana, las personas que pasaban por la plaza se detenían algunos minutos para observar.

Gauna comenta que una de las articulaciones que se realizan con las actividades de CineZap, tiene que ver no sólo con la visibilización de las ideas e historias de los jóvenes en los cortometrajes, 
sino que, durante todo el proceso de creación, se genera una fuerte vinculación entre los docentes, los jóvenes, la familia y los vecinos del barrio:

"El proyecto de cine promueve la vinculación de la comunidad, la familia y la escuela. A partir del trabajo de los alumnos, la escuela va al barrio a registrar las historias que los alumnos desarrollan, se mete en la casa de los chicos en los rodajes durante varios días y articula relaciones diversas. Pone a los alumnos como sujetos activos de la relación vincular y a partir de esa participación genera espacios donde compromete la participación de la escuela, las familias y el barrio." (Gauna, 2014, p.15)

Durante el segundo día de grabación, los jóvenes se mostraban bastantes motivados e interesados, tanto en participar como en aprender, especialmente sobre el manejo de los equipos como la cámara y grabador de audio.

Tanto para el equipo de cámara, como para iluminación, se habían conformado grupos de 3 o 4 chicos para que pudieran turnarse en las tareas. Ese día los chicos que no habían manipulado mucho los equipos durante el primer día, manifestaron su deseo de hacerlo, por ejemplo, el área de cámara estaba conformada por 3 chicos, los dos jóvenes que no manipularon la cámara durante el primer día empezaron a discutir amistosamente sobre quién grabaría ese día, ninguno de los dos quería ceder, así que lo resolvieron jugando "piedra, papel o tijera", un juego en el que se usan las manos, cada uno elige uno de estos tres elementos y lo representa con su mano, así el que haya elegido el elemento más fuerte gana. De esta manera se definió quien manipularía la cámara ese día.

Este es uno de los ejemplos de la motivación que genera en los estudiantes, la propuesta educativa que les hace CineZap. Les estimula e invita a empoderarse de su propio proceso de aprendizaje, al respecto Gauna afirma:

"Revaloriza las capacidades particulares de los alumnos. Promueve el trabajo en equipo, potenciando la idea de que cada uno es necesario para la tarea y los estimula para que tomen la palabra. Intenta lograr que por un momento se sientan protagonistas, confiados, capaces de lograr cosas por sus propios méritos.” (Gauna, 2014, p.13) 
Ese se grabaron un par de escenas dentro de las instalaciones de la escuela, pero a la tarde se había planeado grabar en las calles aledañas. Se debían grabar un par de momentos en que tanto el personaje del "maestro mayor de obra" como los "ladrones" caminaban o corrían por la calle. Antes de salir, Fernando y Mariana les recordaron la importancia de estar siempre en grupo y estar atentos a los equipos y objetos personales.

Empezaron la grabación de estas escenas en la calle y hubo un momento en que un grupo de 4 jóvenes de 18 o 20 años aprox se acercaron a mirar la actividad. Al parecer los jóvenes vivían por el barrio, se acercaron a preguntarle a los chicos que hacían, pero estos se mostraron incómodos, tanto Fernando, Mariana y los pasantes se pusieron atentos a la situación. Estos jóvenes empezaron a preguntar por la cámara y se preguntaban entre ellos cuánto podría costar un equipo como ese, en vista de que los jóvenes se acercaban demasiado a la cámara todos nos pusimos incómodos y empezamos a levantar los bolsos y demás objetos.

Los jóvenes tomaron un tono más agresivo con sus comentarios, la docente Mariana les dijo a los chicos que levantaran todo y volviéramos a la escuela, uno de los chicos comentó que faltaba grabar tan sólo una acción, pero la docente insistió. Los chicos levantaron todo rápidamente y empezamos caminar hacia la escuela mientras los jóvenes nos observaban desde una esquina.

Esta anécdota representó una situación incómoda para todo el grupo. Conversando posteriormente con los chicos, mencionaban que en el barrio se sabía que esos jóvenes eran "chorros", esta es la palabra que usan para referirse a quienes roban y delinquen. Como he mencionado, CineZap interviene en escuelas medias del sur de la ciudad de Buenos Aires, y también mencionaba que suele ser una generalidad que estas escuelas estén ubicadas en zonas donde la desigualdad de condiciones económicas, los niveles de violencia, delincuencia, consumo y expendio de drogas, son mucho más marcados que en otras zonas de la ciudad.

Lo que quiero recalcar en este punto, es que suele generalizarse que las personas que habitan estas zonas son estigmatizadas, no solamente por su condición económica, sino también por considerárseles actores de hechos violentos y delictivos. A los jóvenes por el simple hecho de vivir 
en estos sectores se les estigmatiza de "chorros" o ladrones, esta problemática es una realidad con la que chicos de estas escuelas deben convivir, y en muchos casos les generan dificultades a la hora de conseguir trabajo.

Conscientes de esta problemática, desde CineZap manifiestan su intención, de que las clases de cine y los cortometrajes que se realizan, sirvan como espacios de reflexión al respecto, no sólo para visibilizar la problemática, sino para que sean los mismos chicos quienes analicen y propongan estrategias o alternativas ante este tipo de situaciones.

"Por otra parte, debemos decir que este proceso implica la elaboración de una mirada política sobre la sociedad o sobre sectores y actores de la sociedad por los que siempre nuestros alumnos son mirados. Elaboran una mirada colectiva sobre esa sociedad que los estigmatiza, objetivándolos a través de una trama de valores, juicios y prejuicios de la que son siempre objeto y nunca protagonistas, sobre la que alguna vez opinan, pero a la que nunca miran ni nombran.” (Escobar, Gauna, González, Morabes, 2012, p.5)

En muchos casos, estas situaciones de violencia o delincuencia, son usadas en las clases de cine para reflexionar sobre su contexto, sobre los jóvenes como actores de sus realidades y les invitan a adoptar una mirada crítica al respecto. En algunos casos son conversaciones que se tienen dentro de la clase y en otras logra trascender esta reflexión y es llevada a las historias que plasman en los cortometrajes que ellos mismo realizan, al respecto Luna afirma:

"Utilizando las propuestas de los alumnos como excusa, se realizan discusiones reflexivas sobre las situaciones presentadas. Tomando como punto de partida las situaciones de peligro social a las que ellos están expuestos, piensan cuales son las variables que están en red, y a partir de ese análisis se proyectan otras salidas posibles, otras soluciones viables.” (Luna, 2012, p.213)

El tercer día de grabación fue un sábado, a los chicos se les citó a las 9 de la mañana en las instalaciones de la escuela, allí nos recibió un profesor y un encargado de mantenimiento. Entramos todos al patio, Mariana y Fernando les dieron algunas indicaciones: inicialmente se grabaría en el 
taller, posteriormente en el salón grande de convenciones y a la tarde en el comedor de los profesores.

Los chicos empezaron a sacar los equipos y a prepararlos, estaban mucho más confiados que el primer día, sabían cómo manipularlos y no pedían ayuda a los docentes o pasantes a menos que surgiera algo extraordinario.

Las primeras escenas del día se grabaron en el taller, allí debían grabar el momento en que el arquitecto estaba en la obra y algunos de los obreros toman mate. El taller es un salón extremadamente grande y largo, similar a un galpón, tiene diferentes máquinas y tornos intercalados por mesas grandes y bancos de madera. Al final del salón hay pilas de materiales como maderas, bloques y vigas; en este lugar se simularía el escenario de la obra.

Los chicos empezaron a grabar las escenas, después de aproximadamente una hora, debían realizar una toma del arquitecto hablando por teléfono, estaba previsto que esta acción se realizaría cerca de la entrada del salón, pero el actor propone que mejor la realicen cerca de unas escaleras de cemento, simulando que él baja las escaleras y de paso patea un tacho. Yucra, el director, se muestra motivado con la idea y le pide al camarógrafo ubicar la cámara frente a las escaleras.

Este fue uno de los pocos momentos en que vi a Yucra, proponer una idea o tomar la iniciativa. Tan pronto iban a empezar a grabar la acción, llegó la profesora Mariana y les preguntó cómo iban, los chicos entusiasmados le comentaron lo que iban a grabar, pero Mariana se mostró alterada, les dijo que así no era como lo habían planeado, le pidió al actor que se bajara de las escaleras y realizaran la toma según la idea inicial. A los chicos les cambió la expresión del rostro, pero rápidamente obedecieron a la docente.

Si bien una de las premisas de las prácticas de CineZap, es la reformulación de las relaciones docente - alumno, como afirma Huergo, procurando un reconocimiento del otro como igual, con el fin de desnaturalizar las prácticas hegemónicas. Tanto en este caso, como en la situación anteriormente narrada, donde los jóvenes encargados del guión proponen cambiar el nombre a los personajes principales, la docente Mariana se mostró reticente y los jóvenes parecían molestos y 
resignados. Se evidencia una tensión entre esta premisa y la realidad de las prácticas dentro la escuela, el docente se reafirma en su rol de líder y poseedor del conocimiento y el estudiante en un actor pasivo dentro del proceso de aprendizaje. Aparentemente estas actitudes de la docente no solamente coartan la iniciativa de los jóvenes, sino que les recuerda y reafirma las dinámicas en las que están inmersos, les recuerda que se encuentran dentro de la escuela, en una actividad académica, y por ende, no tienen permitidas algunas libertades.

A su vez, ésta anécdota, pone en tensión y cuestiona de manera importante otra de las premisas del programa CineZap, la que promueve el empoderamiento de los jóvenes y les invita a ser ellos quienes creen y cuenten sus historias, desde sus opiniones, perspectivas y motivaciones. Al parecer la invitación a la autonomía y a la creatividad se ve en confrontada por las estructuras hegemónicas vinculadas a la relación docente-alumno de la escuela tradicional.

Llegado el mediodía Fernando comentó a los jóvenes que siguieran con el proceso de grabación, mientras él se hacía cargo del almuerzo de ese día. Previamente se había acordado con la docente Mariana, destinar un recurso económico asignado para las viandas de ese día, para comprar hamburguesas "Paty" y realizarlas en la parrilla, a modo de asado, como celebración del último día de grabación.

Los chicos terminaron de grabar las escenas en el taller y se desplazaron hacia la zona del comedor de los docentes, esta se ubicaba del lado derecho del edificio, se ingresaba por un pasillo, había un salón mediano con sillas y mesas para comer y de un costado había otra puerta que daba a un patio pequeño; de fondo había una cocina pequeña y los baños. En el centro del patio había una mesa redonda de cemento terminada con trozos de azulejos y a un costado estaba la parrilla.

Cuando los chicos se dirigían hacia el salón de los profesores, en el patio ya se encontraba Fernando que ya ha encendido las brasas y empezaba a poner las hamburguesas en la parrilla, los chicos se miraban entre ellos, sonríen y comentaban, se veían entusiasmados.

Si bien la tradición de realizar asados está muy arraigada a la cultura argentina, también es una práctica muy común dentro del ámbito de la construcción, realizar asados cuando se debe trabajar 
los días fines de semana. No solamente representa un almuerzo diferente al que suelen comer durante los días de semana, sino que, para los jóvenes del grupo, genera un ambiente de camaradería y compañerismo.

\subsection{Escena 16 - Int - día - Etapa de postproducción, la edición del cortometraje, cierre del proceso}

La etapa final de la realización del cortometraje es la edición de todas las escenas. Como se grabaron en un orden diferente al del guión, se les organiza de tal manera que se entienda la historia, se agregan los sonidos y musicalización deseada y se hacen correcciones de luz o de color.

Para este proceso es necesario un equipo o computadora con los programas adecuados para la edición. Debido a que la escuela no contaba con este tipo de programas, la edición se realizó en la FUC, allí la universidad, en acuerdo con CineZap, dispuso un salón con los requerimientos técnicos y un estudiante avanzado de la carrera de cine, quien les ayudó a los chicos a editar.

El cortometraje final, puede visualizarse en el sitio web de CineZap con el siguiente link: http://cinezap.com.ar/?p=2703

Es recién en esta etapa cuando tienen una noción mucho más concreta de todo el proceso de realización. Al iniciar el año y durante la creación del guión, los jóvenes se mostraban incrédulos ante la propuesta, posteriormente durante la grabación alcanzaban a visualizar un poco más la idea del cortometraje, pero es realmente en la etapa final donde comprendieron por completo el proceso de creación.

Durante la grabación tan sólo veían fragmentos de las escenas y de esta manera lograban imaginarse cómo iba a quedar la versión final, pero no les resulta fácil visualizar cómo quedará el cortometraje final. Además, durante el proceso de grabación también comprenden desde la propia experiencia, todo lo que hay técnica y creativamente detrás de las producciones audiovisuales. Conversando con Micaela, la única chica del grupo me comenta: 
“...después verlo, vimos algunas partecitas, no armado, sino algunas escenas así todas mezcladas, está quedando muy bueno. Es raro porque vos... es muy distinto lo que ves, que son todas las cámaras, la iluminación, el micrófono y como se ve cuando lo ves en la compu o en la pantalla, no se ve nada, sólo se ven los actores, y está bueno porque sabés que detrás de eso hay muchas cosas” (Micaela Cardozo, estudiante)

Pasar por las clases de CineZap significa para los jóvenes la adquisición de conocimientos relacionados a la realización audiovisual, que interiorizan desde lo vivencial, desde la experiencia; no solamente conceptos técnicos, sino el refuerzo de valores como el trabajo en equipo, la autonomía y el empoderamiento como autores de sus propios relatos.

"Por otra parte la participación activa en los procesos de producción y realización permiten constituir grupos operativos y de aprendizaje que transforman la actitud de los estudiantes que paulatinamente logran modificar su actitud frente a los contenidos audiovisuales al transitar ellos mismo por una transformación cognitiva que los saca de esa posición de público destinatario/audiencia o de receptor fundamentalmente pasivo y acrítico movilizándolos y transformándolos en ciudadanos productores/creadores." (Gauna, 2014, p.6)

En este punto, al ver finalizado su cortometraje, los jóvenes generan otro tipo de análisis y reflexiones. El pasar por esta experiencia les llena de argumentos para leer y comprender no sólo las producciones audiovisuales que consumen, en la televisión o el cine, sino que les dota de un criterio, para ver que existen otras formas de aprendizaje diferentes a las vivenciadas tradicionalmente en el aula.

De igual manera, esta experiencia sirve a los jóvenes para reivindicarse en su rol de sujetos de derecho, de ciudadanos con iguales beneficios. Les muestra cercano un mundo que parecía inaccesible. Evidenciando que a sus escuelas y a sus barrios también llegan las oportunidades que tienen jóvenes de escuelas de otras zonas de la ciudad. 
"Pensamos el dispositivo, no solamente como herramienta para la Inclusión -como inicialmente fue creada- sino también como un espacio para democratizar y repensar el campo simbólico, para modificar la apropiación desigual de este campo y para tratar de modificar miradas y percepciones sobre el mundo y sobre cada uno. Contamos con la ventaja de que no es necesario quitar a otro el conocimiento para redistribuirlo sino que este puede ser generado en un acto de independencia y autonomía liberadora." (Escobar, Gauna, Gonzalez, Morabes, 2012, p.4)

Después de editado y finalizado el cortometraje, CineZap, como es costumbre, realizó un evento en donde invitó a los participantes de las siete escuelas a ver todos los cortometrajes realizados ese año. Este se realiza por lo general en salas de teatro o auditorios, para esa ocasión, fue en el auditorio del colegio Félix Bernasconi. La docente Mariana gestionó el permiso y el transporte para que los jóvenes del grupo pudieran asistir al evento.

Posterior este suceso, CineZap, en su sitio web oficial y en sus redes sociales, publicó un video recopilando imágenes del encuentro. En el muestra a jóvenes participantes de todas las escuelas, dando sus opiniones acerca del proceso. A continuación, transcribo algunos de los comentarios de los jóvenes de la escuela Técnica Número 17 Brigadier General Don Cornelio de Saavedra.

Al preguntarles qué opinaban acerca de haber pasado por esta experiencia, algunos de los jóvenes afirmaron:

"Para mí fue una experiencia maravillosa, trabajar en grupo, estar con mis amigos que conozco y hacer cosas que nunca hicimos antes, me pareció algo incré́ble"

"Estuvimos más unidos con las personas que no estábamos tan cercanos, nos unimos más al hacer el corto"

"En el principio era un desastre, no teníamos nada, osea por partes... y después de a poco fuimos poniendo todo en su lugar y quedó muy bueno" 
Frente a la pregunta sobre qué aprendieron al realizar un cortometraje, comentaban:

"A cómo expresar una idea, que se entienda, la coherencia... a escribir"

"Aprendí a expresarme mejor"

"Aprendimos a ser más responsables de nuestras cosas, que si no sos responsable las cosas salen mal"

Posteriormente ante la pregunta sobre qué les aconsejarían a los jóvenes que van a participar los años siguientes de la experiencia de CineZap, respondieron:

"Les diría que lo disfruten, que se esfuercen, que no sean vagos, que es una experiencia muy linda y que no todos pueden hacer esto"

"Que antes de hace el corto se organicen todo antes..."

"Que disfruten porque es una buena experiencia, y puede llegar a que les guste y sigan haciendo eso"

Cuando les preguntaron sobre qué opinan de que se implementen más actividades de realización audiovisual en las escuelas, comentaron:

"Esta bueno que lo implementen en otros colegios porque ayuda mucho a desarrollar ideas, o a expresarse mejor"

"Esta bueno porque es divertido, y porque después cuando los ves es como que te queda, es una cosa que nos va a quedar para toda la vida" 
Finalizado el proceso de CineZap en las escuelas, los jóvenes que participaron, cambiaron su percepción no sólo frente a la realización audiovisual, sino que también reflexionaban acerca de otras formas y tipos de aprendizaje. Se dieron cuenta que dentro de la escuela también hay lugar para propuestas alternativas a la educación tradicional. Además, comprendieron y valoraron el hecho de ser ellos los autores de sus propios discursos e historias:

"Si el acto de comunicación realmente lo comunica con otros, el alumno construye una conciencia de cuánto vale él y su discurso. Cuánto vale lo que tiene para decir, su relato y su historia. Si alguien es destinatario de sus anuncios y denuncias, entonces vale la pena el esfuerzo de aprender." (Gauna, 2014, p.10)

\subsection{Escena 17 - Int- día - Tensiones y transformaciones}

La historia que construyó este grupo, da cuenta de la realidad, el contexto y la mirada de quienes participan de este proceso, es una construcción colectiva de sus perspectivas, la materialización de sus experiencias. La historia de un arquitecto y un maestro mayor de obra en el escenario de una construcción edilicia, no es un planteo fortuito, son decisiones basadas en los modelos y referentes con los que conviven directamente, como el hecho de que todos hayan optado por la especialidad de construcciones civiles, los personajes y escenarios son referentes cercanos a su cotidianidad.

El conflicto narrativo que plantean con su cortometraje, también da cuenta de una preocupación latente: el robo, la delincuencia y la inseguridad. Son problemáticas con las que coexisten, de las cuales posiblemente han sido víctimas o conocen alguien que lo haya vivido. A partir de ello constituyen un mirada crítica ante un conflicto social, una voz de denuncia y de insatisfacción. Cavando más profundo, en las interlíneas de la trama, se observa un pronunciamiento frente a la diferenciación de clases sociales, con la construcción de los personajes, se refuerza la estereotipación de la clase media y de la clase alta. 
El uso del lenguaje y esquema de producción del audiovisual, entendidas como un dispositivo de intervención (Gauna, 2014), apela a una ruptura y una tensión de las formas de aprendizaje, relevando la construcción de discursos en reemplazo del adoctrinamiento. Huego afirma: "de allí, también, que las estrategias pedagógicas deberían tener más en cuenta el contar/relatar de los sujetos, que el concientizar a los sujetos; deberían tener más relación con el reconocimiento que con el conocimiento" (Huergo, 1997, p.150). La construcción de relatos, de narraciones con voces propias, posicionan a los sujetos en el lugar de autores, y les invitan a reflexionar no solamente frente a conceptos impuestos por una autoridad en el aula, sino que les habilita a proponer sus propios discursos.

Las prácticas de CineZap dentro de las dinámicas de la escuela, proponen una visión transformadora frente a los procesos de aprendizaje, frente al sujeto, a la construcción individual y colectiva de perspectivas. Transformaciones que son vividas de diferentes maneras y afectan a los sujetos de formas únicas. Se parte de la premisa de que cada individuo lleva consigo una trayectoria y experiencias que le posicionan en su relación con el otro, y al transitar por el recorrido que proponen las actividades de este programa, cada persona va transformando sus miradas, miradas frente a la escuela, a los docentes, a los procesos de educación, a lo colectivo y a lo individual, pero sobre todo su mirada frente al empoderamiento.

Quienes participan de este proceso, estudiantes, docentes, practicantes, familiares y toda la comunidad involucrada, están sujetos a las diferentes tensiones que se producen ante la ruptura de algunos paradigmas. Paradigmas como el rol del docente y el rol del alumno (Tiramonti, 2011), donde se pone en tensión las relaciones de poder: los estudiantes cuestionan la autoridad de los docentes, y los docentes reafirman su postura de jerarquía dentro la institución y las prácticas escolares.

Ejemplos como las tensiones entre estudiantes y docentes al momento de toma de decisiones, como el caso de la elección del nombre de los personajes del cortometraje, o el cambio de una de las escenas durante el momento de la grabación, dejan ver el peso del legado que durante siglos ha 
tenido la estructura clásica de la escuela. CineZap se enfrenta al reto de re-significar estas estructuras, lo propone dentro de su planteamiento metodológico, pero durante la práctica se ve truncado ante el paradigma del rol del docente como autoridad dentro del aula y el rol del estudiante como receptor pasivo dentro del proceso de aprendizaje.

\section{CAPÍTULO 3: Hacer cine en la escuela media, entretejiendo la realidad y la ficción}

A partir de este punto empezaré a recrear el proceso de formación en cine que se llevó a cabo durante el año 2016 en la Escuela de Educación Media N ${ }^{\circ} 6$ Distrito Escolar 5 con el grupo de cuarto año. Esta escuela se caracteriza por estar ubicada en la villa 21-24 de la ciudad de Buenos Aires, uno de los asentamientos informales más grandes de la ciudad, conocida por sus altos índices de violencia e inseguridad. El grupo con el cual se desarrollaron las clases de cine se caracterizaba por estar compuesto en su gran mayoría por mujeres, con edades entre los 16 y 20 años, muchos de ellos habían repetido grados en la misma o en otras escuelas.

De las actividades realizadas durante las clases de cine, profundizo en el proceso de selección del tema y creación del guión, de allí recreo los debates y momentos en los cuales los jóvenes construyen la historia que quieren narrar. Posteriormente, hago énfasis en los días de grabación y en las diferentes anécdotas que surgen, proponiendo reflexiones teóricas en torno al empoderamiento por parte de los jóvenes, el trabajo conceptual relacionado al lenguaje y el audiovisual propuesto por los docentes y las relaciones de poder que se dan dentro y fuera del aula de clases.

\subsection{Escena 18 - Int - día - La experiencia de hacer cine en la escuela media}

En el 2016 durante los meses de abril y noviembre, participé del proceso de CineZap en la Escuela de Educación Media N 6 Distrito Escolar 5 con el grupo de cuarto año, en este caso, las clases de cine se vinculaban con las materias de Literatura y de Filosofía. Tras previas conversaciones entre los coordinadores del programa y los docentes y directivos de la escuela, acordaron vincular las dos materias de la siguiente manera: durante el primer cuatrimestre se trabajaría con la materia de 
Literatura y para el segundo cuatrimestre con Filosofía, de esta manera las docentes podrían avanzar con los contenidos del curriculum y a la vez desarrollar el programa de CineZap, que en esta escuela era dictado por el docente Lisandro, quien llevaba 4 años consecutivos como docente de cine de este programa.

Este grupo estaba conformado por 18 jóvenes de entre 16 y 20 años, de los cuales 14 son mujeres y tan sólo 4 hombres. Por lo general nunca estaban todos, el promedio es de 15 chicos por clase. Varios de estos jóvenes son repitentes de la misma escuela o de otras escuelas. Por ejemplo, había una chica llamada Milagros que tenía 20 años y había repetido varios grados. También en el grupo había una joven que estaba embarazada y para el segundo cuatrimestre iba a tener su bebé y otro joven que asistía con un cochecito y su bebé de 6 meses, la madre era también una joven de la escuela de un grado inferior.

Otros estudiantes además de asistir a la escuela, alternaban su jornada escolar con jornadas laborales, es decir, asistían a la escuela en la tarde y trabajaban en la mañana, algunos en negocios familiares y otros gestionaban permisos firmados por sus padres para poder acceder a trabajos.

Las docentes, tanto Liliana, de Literatura como Paz de Filosofía, vincularon sus clases a las de CineZap durante 3 años consecutivos. La docente de Literatura, Liliana, era una mujer de aproximadamente 40 años, delgada y de cabello rubio, usaba siempre lentes. Dictaba la materia de Literatura para todos los grados del secundario, por lo general llevaba consigo un cuaderno grande y varios libros que solía usar para sus clases. Paz era la docente de Filosofía, era una mujer de aproximadamente 30 años, de cabello oscuro y liso, vestía usualmente de jeans, zapatillas y buzos abrigados, tenía un aspecto juvenil y por lo general se le veía hablando o riendo con los estudiantes en los pasillos durante los cambios de clases.

Lisandro, el docente de cine, era un hombre de 35 años aproximadamente, de cuerpo robusto, cabello castaño claro, peinado de costado, un lado lo llevaba largo y el otro corto a ras de piel. Mi primer encuentro con Lisandro se dió vía telefónica, Cristian Gauna (Coordinador de CineZap), 
me dio su número para que le llamara y coordinara el acompañamiento de las clases de cine en esta escuela.

El primer día, Lisandro me citó cerca de su casa en el barrio de Barracas, me dijo que él pasaría en su auto y me recogería en ese punto para que llegáramos juntos a la escuela. Cuando me propuso esto me pareció perfecto ya que no conocía la zona, además esta escuela está ubicada en la villa 21-24, una zona reconocida por sus altos niveles de inseguridad, aspecto que posteriormente Lisandro me confirmó al decirme que era mejor que llegara con él, ya que le conocían por su trabajo en la escuela y por mi seguridad era mejor entrar al lugar con alguien conocido.

Ese día Lisandro llegó en su auto a la hora pactada, subí y lo saludé, de camino hablamos sobre cada uno, yo le conté sobre mi llegada a la Argentina, mi cursada en la maestría y mi idea de investigación para la tesis, él me comentó que estudió Medios Audiovisuales en el Instituto Vocacional de Arte y cursó la Licenciatura en Dirección Cinematográfica en la Universidad del Cine, que llevaba 4 años vinculado al programa CineZap como docente de cine, los últimos 3 años en ésta escuela en Barracas. También me comentó que vivía con su mujer que estaba embarazada y su hijo de 3 años.

Llegando a la escuela me dí cuenta que el aspecto de las calles iba cambiando, el asfalto estaba más deteriorado y las veredas estaban llenas de comercio informal, desde la venta de ropa hasta alimentos como choripán, fiambres, chipá, panes caseros y verduras. Lisandro estacionó el auto en una calle sin asfalto a un costado de la escuela, las casas tenían todas arquitectura diferente entre sí, parecían en proceso de construcción o sin terminar. La escuela también estaba en proceso de construcción, Lisandro me contó que le estaban haciendo una remodelación y ampliación desde el año pasado.

Cuando entramos a la escuela había una puerta principal de rejas y pocos metros después la puerta de metal que permitía la entrada al edificio, allí había un hombre de aproximadamente 40 años que 
hacía de portero, pero no llevaba ningún uniforme distintivo. Al entrar se veía un largo pasillo y la entrada al patio, al costado derecho otro pasillo y la primera oficina era la de la vicerrectora, había una ventana grande que permitía ver su escritorio. Había muchos jóvenes caminando, hablando y comiendo snacks por los pasillos. Lisandro saludó al portero, entramos y buscamos a la profesora de Literatura, subimos unas escaleras hacia el primer piso, llegamos hasta la sala de profesores donde estaba la profesora Liliana y allí nos presentamos.

Salimos de la sala y en uno de los pasillos cercanos a la biblioteca, hablamos sobre la actividad a realizar ese día, ya que la profesora había escuchado comentarios de que el ejercicio de la sesión anterior (la segunda clase realizada del programa CineZap con este grupo), les había parecido aburrida a los chicos, habían leído varios cuentos e identificado a qué género pertenecía cada uno. Lisandro y Liliana, acordaron preguntarles y si estaban de acuerdo leeríamos otros cuentos que ya habían preparado para esa clase ambos profesores.

Caminamos al salón de clases, un salón amplio con tan sólo 15 chicos, un aula con aproximadamente el doble de sillas. El grupo es de cuarto año, chicos entre 17 y 20 años de edad, en su gran mayoría chicas, 10 chicas y 5 chicos, una de ellas estaba embarazada. Lisandro me presentó frente a los jóvenes, hablé un poco sobre mi recorrido e intenciones de acompañarlos en ese proceso y allí Lisandro retomó el tema de los cuentos y los géneros literarios. Los chicos un poco tímidos al principio iban respondiendo lo que él les preguntaba y la profesora Liliana hacia pequeñas acotaciones.

Después les propusieron a los chicos que leyeran un par de cuentos que Lisandro había traído sobre el género de terror, tema que ellos habían manifestado que les gustaba más. Nos sentamos en círculo y Lisandro empezó a leer en voz alta el primer cuento. Algunos de ellos prestaban atención, un par miraban o escribían cosas en sus cuadernos, la profesora, sentada a mi lado prestaba atención también. Al finalizar la lectura Lisandro pidió a los chicos que reconstruyeran con sus palabras la historia y charlaron acerca de los elementos que generaban terror, suspenso o miedo y salieron comentarios como: "la verdad, yo no sentí miedo"; "asusta más... quien sabe que..."; "no es como en las películas, como que no llegás a sentir miedo de verdad". 
Al finalizar la lectura sonó el timbre y la clase finalizó. Nos despedimos de los chicos y en el pasillo hablamos los tres sobre la clase siguiente, la propuesta de Lisandro fue ver la posibilidad de proyectar cortometrajes basados en cuentos o en piezas literarias, la profesora Liliana estuvo de acuerdo así que fuimos a hablar con el rector quien, tras varias excusas, como que no sabía si había reproductor de DVD, o que no había cables para conectar la computadora, concluyeron que era complicado realizar la proyección en la escuela.

En ese momento la profesora Liliana recordó que en la Casa Cultural, que quedaba conjunta a la escuela, había un auditorio que podía usarse para hacer la proyección, ella se comprometió a concretar el espacio. Para esa actividad se necesitaba un poco más de tiempo de clase así que fuimos a hablar con la profesora de Filosofía: Paz, que también iba a trabajar las clases de cine en su materia, para pedir a ella la hora siguiente a la clase de literatura del día martes, para realizar una jornada de mínimo dos horas de proyección, ella estuvo de acuerdo, pero por actividades de la escuela (una pequeña inauguración del edificio nuevo) y por acontecimientos políticos (la citación a la ex-presidenta Cristina a los juzgados de Comodoro Py) algunos docentes no asistirían a la escuela, y esa semana sería complicado coordinar con los chicos y profes, así que se acordó realizar la actividad la semana siguiente, es decir a los 15 días. Tras esos acuerdos, nos despedimos y salimos de la escuela.

De este primer acercamiento que tuve con esta escuela, quisiera reflexionar acerca de un par de aspectos; el primero de ellos: el embarazo en adolescentes, al entrar al aula, una de las cosas que más me llaman la atención es la chica que está embarazada y el chico que está con el cochecito de su bebé. Si bien es sabido que una de las problemáticas más visibles de los jóvenes que habitan los barrios populares es el embarazo en adolescentes, también me llama la atención indagar más acerca de lo que opinan al respecto tanto los jóvenes como los docentes de esta escuela. 
En conversaciones posteriores con la chica que estaba embaraza y con otras de sus compañeras, me comentaban que si bien en este caso, como en el de amigas y familiares, el embarazo no suele ser planeado, no piensan en esto como un error o una equivocación. Les pregunté acerca de cómo se informaban sobre los métodos anticonceptivos y comentaron que en la escuela desde los primeros años del secundario les daban charlas o clases sobre sexualidad y anticoncepción, conocían los métodos, hablaban sobre los preservativos o sobre las píldoras, pero decían que no solían usarlos por dos motivos principalmente: porque dicen que son costosos y porque dicen que si quedan embarazadas no lo ven como un problema, por el contrario, lo ven como el curso natural de la vida.

Acerca de este tema, Silvia Duschatzky en su libro La escuela como frontera. Reflexiones sobre la experiencia escolar de jóvenes de sectores populares a partir de su trabajo en escuelas secundarias de la Ciudad de Buenos Aires afirma:

"Respecto de este fenómeno cabe destacar dos características: la mayoría de los jóvenes cuenta con información sobre prevención y Sida, pero deposita los recaudos en los designios del varón. A su vez, la posibilidad de interrumpir el embarazo está fuera de sus expectativas. Teniendo en cuenta las notas de un contexto en el que la mujer gana presencia, habría que inscribir el rechazo del aborto no tanto en creencias morales sino en la necesidad de aferrarse a la vida. La pareja aparece entonces como un efecto consecuente y no como opción. Así mismo la maternidad no surge de una planificación familiar sino que es la respuesta a una emergencia socio - afectiva.” (Duschatzky, 1999, p.7)

Posteriormente, en el transcurso de todas las clases de CineZap con este grupo, observé que efectivamente esta chica embarazada recibía tratos especiales por parte de sus compañeros y docentes. Tenía ciertas licencias, como faltar varios días a las clases, plazos para presentar trabajos o exámenes o salir antes de la hora establecida por la escuela. Ante esto la joven manifestaba 
sentirse "beneficiada" por su embarazo y se sentía contenida y apreciada por sus compañeros y profesores.

Por otro lado, indagando en conversaciones posteriores, algunos jóvenes comentaban que habían aplazado su obligación de trabajar para poder terminar el secundario y conseguir un empleo mejor pago. También estaba el caso de dos jóvenes, una chica y un chico, que alternaban su jornada escolar con trabajo, es decir, a la mañana trabajaban y a la tarde asistían a la escuela.

Duschatzky observa situaciones similares en su investigación y comenta:

"La escuela se presenta como la institución proveedora de derechos, del derecho a participar del "progreso" y a recibir la confianza del otro. La idea de progreso tiene aquí un sentido particular, no es el progreso entendido como ascenso social sino como posibilidad de despegue de la fatalidad de origen. Participar de la cultura escolar implica para algunos jóvenes apropiarse de los códigos necesarios para dialogar con el mundo.” (Duschatzky, 1999, p.15)

Conversando con unos de los jóvenes, me comentaban que a veces sus amigos lo "cargaban", es decir, se burlaban de él por asistir a la escuela, ya que muchos de ellos dejaron el secundario o por falta de interés o por la obligación de trabajar. Comentaba que a veces le molestaba esto, pero que al final no le daba importancia, que prefería terminar el secundario y ver si podía conseguir un trabajo mejor remunerado que el que conseguiría si no terminaba sus estudios.

Ante esto, es claro que una de las preocupaciones más evidentes de estos jóvenes está relacionada con el campo laboral, en algunos casos prima la necesidad económica por sobre la educativa, y en otros casos los jóvenes aspiran terminar el secundario, no solamente por el aprendizaje que este les pueda brindar, sino porque afirman que con el secundario completo pueden aspirar a trabajos que les proporcionen un mejor ingreso económico. 


\subsection{Escena 19 - Int - día - De la literatura al audiovisual}

Para la actividad de la clase siguiente, los profesores Lisandro y Liliana acordaron elegir uno de los cuentos de terror que habían leído en la clase anterior, para trabajar con los chicos, debían armar grupos y seleccionar una escena para representarla y grabarla.

Lisandro explicó a los chicos en qué consistía el ejercicio, recordaron los dos últimos cuentos leídos y entre todos decidieron seleccionar el que llevaba por título: Cuento de los angelitos, de la autora Elsa Bornemann. Lisandro les hizo un pequeño recuento, este narraba la historia de una joven pareja que tenía un par de hijos pequeños de 7 y 4 años, cansados del pueblo donde vivían se mudaron a la ciudad en busca de una mejor vida. Allí se instalaron en un barrio humilde cerca de los límites urbanos. Un par de meses después al hombre le ofrecieron un trabajo temporal de albañil al sur del país, inicialmente el hombre se negaba a dejar sola a su familia, pero su mujer le convenció ya que representaba una gran oportunidad económica para la familia.

Después de que el hombre se fue, la mujer y sus hijos tenían por costumbre trasladarse todos los sábados a la mañana hacia el centro de la ciudad, hasta la cabina telefónica más cercana para llamarle. Para llegar debían caminar varias cuadras, pasar por un paso a nivel y atravesar las vías del tren para llegar a la parada de colectivo que les llevaba al centro.

Un sábado, como era de costumbre, la mujer y sus dos hijos iban de camino a llamar al padre, de repente el más chico le pidió detenerse porque debía orinar, en eso, un hombre que les observaba se acercó sigilosamente por detrás de la mujer, la golpeó y le robó el bolso. Cuando la mujer logró reaccionar, corrió para recuperar su bolso donde tenía el poco dinero que le quedaba para terminar el mes; corrío pero el hombre era más rápido, los pequeños lloraban e intentaban correr tras su madre, pero no iban a la misma velocidad, el ladrón y la madre atravesaron el paso a nivel y unos segundos después el par de niños intentaron cruzar también, pero justo en ese momento pasó el tren que no logró frenar y mató a los dos pequeños.

La madre y el padre debieron continuar su vida y decidieron no tener más hijos. Pero al ladrón lo atormentaba la culpa por varios años. Desde aquel momento empezó a sentir una especie de 
paranoia, siempre que iba a agarrar o estaba cerca de los trenes, sentía a su lado pequeños pasos y las voces de aquellos niños. Hasta que en una ocasión, 20 años después del accidente, el hombre se animó a trasladarse en tren, sintió pánico pero aun así esperó decidido en la estación de tren, a pocos segundos de que el tren se detuviera, la gente a su alrededor vió como dió un par de pasos y se lanzó a la vía, lo último que el hombre recordaba antes de morir fue haber escuchado pequeños pasos y dos pares de manos de niños que le empujaban hacia la vía.

Posteriormente, Lisandro les pidió que crearan dos grupos. Cada grupo seleccionó un fragmento para trabajar, lo leyeron de nuevo y definieron quienes iban a actuar y quienes a grabar. Escribieron una lista de acciones para representar y se designaron tareas como llevar el vestuario, algunos elementos de utilería y efectos de sonidos para la clase siguiente.

En el encuentro de la semana siguiente, se realizó la grabación de las historias que cada grupo planeó. Lisandro acompañó a un grupo y yo al otro, cada uno llevaba consigo una cámara con micrófono. Tan pronto Lisandro les dió unas indicaciones previas, cada grupo salió a realizar la grabación, con mi grupo nos desplazamos hacia una calle que estaba al costado de la escuela, para ello la docente Liliana habló con la vicerrectora quien nos autorizó la salida.

La escena que mi grupo iba a grabar, era el momento en que el ladrón golpea a la madre y sale a correr, detrás de ellos el par que niños corren también y el tren les atropella. Estando allí se empezaron a grabar las primeras imágenes, ya se había elegido los actores y tres chicas habían dicho que querían hacer de camarógrafas, así que ellas se van turnando la cámara y cada una tuvo la oportunidad de grabar un fragmento de la escena. Grabando el momento en que el chico que representaba al ladrón, debía acechar a la protagonista, al joven le costaba trabajo realizar la acción y que se viera natural o fluida. Las chicas del grupo empezaron a criticarle, le decían cosas como: "Este no sabe actuar"; "Tenés que hacerlo más creíble, ipareces un gil!"; "Para la próxima que actué otro". El chico se intimidó un poco y tuvimos que repetir la acción varias veces.

Después de un rato, se acercó la profe Liliana para decirnos que quedaba muy poco tiempo de clase; así que tuvimos que apurarnos para terminar de grabar la historia y regresar al salón. 
Para la clase de la siguiente semana, se había reservado el espacio del auditorio de la Casa Cultural, al llegar al salón ya se encontraban allí la profe Liliana y un grupo de 12 chicos, ella ya les había explicado que iríamos a ver unos videos, así que salimos rápidamente. Al dirigirnos hacia la puerta, el portero detuvo a los chicos y les preguntó hacia donde iban, en eso se acercó la profesora Liliana y le explicó que íbamos a la Casa Cultural, él se hizo a un lado y los chicos salieron. Ellos caminaron inmediatamente hacia la izquierda de la puerta, se ve que ya conocían el camino.

La Casa Cultural, estaba ubicada en el edificio contiguo a la escuela, una edificación muy nueva y moderna con ventanales enormes que dejaban ver el interior. Los jóvenes entraron directamente saludando, al parecer ya los conocían los porteros del edificio. Detrás entramos Lisandro, Liliana y yo, los chicos y Liliana se dirigieron directamente al auditorio y Lisandro y yo fuimos a la cabina de proyección. Desde allí se podía observar el auditorio, un espacio muy amplio y nuevo, con capacidad para aproximadamente 100 personas y una pantalla de proyección que ocupaba toda la pared. La cabina estaba dotada con dos grandes video proyectores, varios reproductores de video, consolas de audio y computadoras modernas. Había dos hombres de aproximadamente 25 años coordinando la cabina, les dimos un pendrive con los videos y fuimos al auditorio.

Allí se proyectaron los dos videos grabados en la clase anterior, mientras los veían se escuchaban fuertes risas y comentarios. Al finalizar les preguntamos qué opinaban, surgieron risas y comentarios como: "Rodrigo no sabe correr... jajaja” "Que Moni no vuelva a actuar, le sale re mal jajaja" "A Sabri no se le entiende nada cuando habla...". Siguieron las críticas sobre las actuaciones, los que actuaban se reían o se avergonzaban; una de las chicas comentó: "no vuelvo a salir en un video...". Este tipo de reacciones son recurrentes cada vez que los chicos se ven en la pantalla, surgen burlas o halagos, se hace mucho énfasis en la forma y se presta poca atención al contenido o a la historia.

Se proyectaron una segunda vez los dos videos, pero en esta ocasión Lisandro y yo previamente habíamos editado los videos, sacando los fragmentos con errores de actuación y agregando música de suspenso; les pedimos que se fijaran en la historia, qué entendían y si generaba miedo o suspenso. Tras ver los videos una segunda vez, se les invitó a analizar más el contenido, algunos chicos decían: "esta vez está mejor pero eso no da miedo"; "la verdad da más risa que miedo"; 
Lisandro indagó al respecto: “y por qué creen que no dan miedo los videos?”, hay un silencio y nadie responde, Lisandro insiste: “A ver pensemos, ¿qué recursos o elementos harían falta para que fueran más de terror?", una de las chicas, Soraida, respondió "la música ayuda un montón, parece más de suspenso pero a la historia le falta ser más de miedo"; otra chica agrega, "meterle cosas que asusten como una sombra o que de repente aparezca un espanto o algo asi'”.

Posteriormente Lisandro les expuso algunos elementos narrativos y estéticos característicos del cine de terror, les fue haciendo preguntas a los jóvenes y entre todos identificaron elementos como: escenarios o locaciones poco iluminadas, persecuciones, una musicalización específica marcada por la predominancia de tonos graves y el elemento sorpresa, que por lo general es dado por el antagonista que aparece de forma violenta e inesperada.

La profesora Liliana les habló acerca de la relación entre la literatura y el audiovisual, acerca del lenguaje y los símbolos que comparten. Les comentó que en muchas ocasiones las películas son basadas en libros, y que en todos los casos, todas las películas empiezan por una historia escrita; por alguien que se imagina, acciones, lugares y diálogos, que luego son escritos con formato de guión para ser llevados al cine. Enfatizó que tanto en la literatura como en el cine, suele usarse la estructura narrativa del inicio, nudo y desenlace y les reiteró la importancia que tiene la escritura de la historia previa a la grabación del cortometraje que realizarán.

Tanto para los coordinadores como para los docentes del programa CineZap, las clases de cine no sólo representan un espacio de inclusión y democratización, también pretenden generar una transformación en las prácticas educativas a partir de la comunicación, específicamente a partir de la exploración del lenguaje audiovisual (Gauna, 2012). De la inclusión de las tecnologías de la comunicación en el aula, Duschatzky expone la importancia del entramado de lenguajes que representan este tipo de experiencias para los jóvenes en las escuelas:

"La comunicación es el eje articulador de estas prácticas juveniles. La radio supone el intercambio con los oyentes, las revistas con los lectores y el centro de ex alumnos la circulación entre la comunidad. Estas tecnologías de la comunicación plantean además la hibridación de registros y lenguajes. Tomadas en su conjunto revelan la mezcla de 
lo oral con lo escrito, del texto con la imagen, de la palabra con el sonido." (Duschatzky, 1999, p.42)

Después del ejercicio algunos jóvenes comentaron acerca de la complejidad de la realización audiovisual, uno de los chicos afirmó: "uh yo pensé que era re fácil, eso de grabar, pero no..." Otra chica le respondió: "si uno ve todo lindo en las películas, y la verdad es que es re difícil hacer que te entiendan ... nuestro video no se entendió nada"

A partir de este primer acercamiento que tuvieron los jóvenes del grupo con el lenguaje audiovisual, lograron tener una idea mucho más clara de lo que les propone CineZap con sus clases. El profesor Lisandro les invitó a reflexionar acerca de, que hacer audiovisual no solamente es aprender a grabar, es aprender sobre el lenguaje de las imágenes y de los sonidos; y en conjunto con la docente de literatura, les reforzaron conceptos como el lenguaje y los símbolos, usando como ejemplo el material que ellos mismos grabaron.

\subsection{Escena 20 - Int - día - Lazos: una historia de terror}

A partir de esta inmersión en el género de terror, durante las clases siguientes, Lisandro y Liliana le invitaron a cada participante, a pensar en una idea para un cuento que tuviera las características del género, con miras a ser seleccionado para la realización del cortometraje final. Después les pidieron que se reunieran en grupos de tres participantes, se comentaran las ideas y trataran de escribir una historia que pudiera ser contada en el cortometraje.

De este ejercicio salieron algunas ideas: un grupo de tres chicas construyeron una historia en donde a una joven la secuestraban en una van o combi blanca, la dormían y le sacaban los órganos para ser vendidos en el mercado negro; al final a la familia le enviaban una nota de agradecimiento por los órganos de la víctima. Según las chicas, esta es una historia que se escuchaba frecuentemente en el barrio, se hablaba de una van o combi blanca que rondaba por el barrio y secuestra jóvenes, se decía que era para tráfico de órganos. 
Cuando este grupo contó su historia al resto de la clase, los demás se sumaron con comentarios como: "ah sí, esa es una historia real, dicen que anda por el barrio", otros afirmaron "si, si, a una conocida de mi vecina le pasó, apareció su hija muerta y dicen que le sacaron los órganos, que fue la combi blanca". Hablando posteriormente con Lisandro, comentaba que este mito parece haberse popularizado en el barrio, que no es la primera vez que lo escuchaba en la escuela, que de hecho, en años anteriores han hecho indagaciones en el barrio, pero nunca se había comprobado que fuera cierto. Lisandro manifestó su intención de hacerles ver a los jóvenes que este podría ser un mito, o en su defecto una estrategia para atemorizar a la gente.

Este fenómeno de la divulgación de un relato, que aparentemente es mentira, pero que se hace tan popular, que las personas terminan por creer que es real, es un tema que aflora al momento de explorar las historias que quieren contar los jóvenes. Para los coordinadores y docentes de CineZap, el momento de creación de los relatos, es un espacio que permite a docentes y estudiantes de las escuelas, reflexionar acerca de las narraciones que circulan en su contexto, dentro y fuera de la escuela, narraciones que de una u otra manera configuran el pensamiento y la visión que tienen los jóvenes acerca de su realidad. Al respecto Luna afirma:

"Creemos no equivocarnos al afirmar que la representación simbólica audiovisual de las temáticas sociales que preocupan a los adolescentes les permiten sistematizar y aclarar sus pensamientos sobre ellas, y estar de ésta manera más preparados para afrontarlas." (Luna, 2012:208)

Si bien no todas las historias que los jóvenes relatan llegan a ser grabadas en el cortometraje final, la etapa de la selección y creación del relato, sirve como excusa para debatir las diferentes problemáticas que plantean los mismos jóvenes. 
Mientras cada grupo trabajaba en sus ideas, veo que una chica estaba en una esquina trabajando sola, me acerqué para conversar con ella, con dificultad levantó la mirada y se negaba a trabajar con los demás jóvenes, tras insistirle, se sumó a un grupo. Empezaron a escribir sus ideas y a los pocos minutos llegó Soraida una chica que estaba fuera del salón, se sentó y se sumó a este último grupo. Les escuchó hablar sobre sus ideas y les dijo que ella ya tenía una historia escrita y sacó una hoja con su cuento. Yo intervine y les pregunté cómo podrían integrar sus ideas a la historia de Soraida, pero ella se negó a que su historia fuera cambiada, así que decidieron presentar este cuento ante el resto del grupo.

Casos similares, a los de esta chica que no quería participar de la actividad junto con el resto del grupo, han sido punto de reflexión por parte del equipo de CineZap. Manifiestan un gran interés en que las clases de cine sean un espacio de inclusión, en donde quienes por lo general no participan, encuentren en estas clases una oportunidad de hacer escuchar su voz, como Cristian Gauna me comentaba: "uno de los objetivos de las clases de cine es incrementar el trabajo con los alumnos menos participativos, segregados de los grupos conflictivos o esquivos a tomar responsabilidades para incluirlos en un proceso integrador de trabajo".

La historia de Soraida se titulaba: Auto suicidio y narraba la historia de una mujer que está en una habitación y decide salir al balcón a tomar aire, en eso un hombre entra silenciosamente, levanta un arma y le dispara por detrás. La mujer cae, el hombre se acerca para verificar que ha hecho bien su trabajo, y al ver el rostro se da cuenta que es la misma mujer que le contrató para llevar a cabo ese asesinato, la mujer había pagado para que le matara.

Los comentarios posteriores a la lectura de este cuento fueron de apoyo y halagos a la historia, algunos jóvenes consideran que estaba bien escrita y que era interesante la idea de que una persona deba contratar a un asesino para matarle porque ésta es incapaz de suicidarse. Los docentes comentaban que en términos de realización era bastante viable ya que transcurre en un sólo lugar, pero mencionaban que debía trabajarse más en los motivos que llevan a la protagonista a querer morir y en el perfil del asesino. 
Otro chico, Ismael, quien en las primeras clases se había mostrado distante y reacio a participar, leyó la historia que había construido con sus dos compañeros. Esta historia era sobre un hombre que cada noche tiene pesadillas, empieza viendo que un hombre quiere asesinarle, pero cada noche, cuando empieza a soñar de nuevo, el asesino está cada vez más cerca, el personaje siente temor de dormir, piensa que está loco y nadie cree en su historia, planea estrategias para hacerle frente al asesino, pero al final muere mientras duerme.

Frente a esta última historia, el docente Lisandro se mostró interesado en la idea, opinaba que se pueden explorar diferentes matices relacionados con el género de terror. Los demás compañeros consideraron que tenía mucho del género que han elegido y podría ser una buena opción para ser contada en el cortometraje.

Después de realizado este ejercicio, el docente Lisandro, propuso que estas historias fueran analizadas en varios sentidos, uno de ellos el de los finales; en todas las historias compartidas por los grupos al final siempre muere el protagonista, entonces se presenta el dilema de cómo crear una historia que tenga los elementos característicos del género de terror pero que a su vez el final represente una alternativa, algo novedoso y que no necesariamente sea la muerte.

En conversaciones posteriores Lisandro me comentaba, que ha sido una iniciativa del programa CineZap, tratar de que los jóvenes piensen que la muerte no siempre es el mejor final. Usualmente el contexto socioeconómico en el que viven la mayoría de los jóvenes que asisten a las escuelas medias del sur de la ciudad, los lleva a convivir con aspectos como la violencia, el tráfico y abuso de drogas u otras problemáticas, y frecuentemente tienen la muerte como la opción más obvia, pero desde estas actividades se les invita a pensar en otras alternativas, en otros finales.

Acerca de esta metodología en la cual se les propone a los jóvenes reflexionar acerca de los temas, los tratamientos y los finales de las historias que construyen, Luna comenta: 
"De este modo, la realización audiovisual les permite a los alumnos indagar sobre las situaciones de su entorno cotidiano. Ante una realidad se esbozan diferentes opciones o alternativas posibles. Esto propicia también interesantes discusiones ideológicas y morales, puesto que resulta más fácil reflexionar sobre la situación cuando se la proyecta en otro.” (Luna, 2012, p.210)

Finalmente, la elección de la historia que se iba a grabar se realizó después de las vacaciones de invierno, es decir tres semanas después de la creación colectiva de las historias anteriormente mencionadas. Durante el siguiente cuatrimestre, al retomar las clases de cine, se hizo en el horario de la clase de Filosofía y con el acompañamiento de su docente: Paz. Para reanudar las actividades, el profesor Lisandro pidió que se organizaran de nuevo en los grupos creados anteriormente y que compartieran las historias para poder elegir, por medio de votación una de ellas.

Los jóvenes se mostraban reacios, decían no tener más las hojas donde habían escrito las ideas. Lisandro les pidió que trataran de narrarlas de acuerdo a lo que recordaran, casi ninguno consiguió reproducir con exactitud su historia; finalmente se lograron reconstruir las historias con ayuda de la profesora de Filosofía, Lisandro y los demás estudiantes. Se analizaron aspectos como la viabilidad en la realización y la duración de las historias, teniendo en cuenta que el cortometraje debía durar aproximadamente 15 minutos; también se tuvo en cuenta la verosimilitud, es decir, que tan creíble resultaba cada historia y cómo podían reaccionar los espectadores al verla.

De todos los grupos, en el que está la joven Soraida, era el que más clara tenía la historia, esta joven había conservado el cuento escrito y aparte había construido un posible perfil del personaje principal, de la mujer que quiere suicidarse, pero no se anima a hacerlo y contrata a alguien para matarla. Después de comentar esto, se realizó la votación, resultó un empate entre la historia de Soraida, y la de Ismael, la del hombre que es asesinado en sus sueños. 
Ante esto Lisandro les propuso trabajar en las dos historias para ver cuál resultaba mejor en términos de realización audiovisual y les propuso reescribir estas dos propuestas, profundizando en las motivaciones de los personajes y en las descripciones de las acciones, los lugares y los personaje. Uno de los jóvenes comentó: "bueno profe si es por eso, elijamos la de Soraida que está más avanzada..." Lisandro les preguntó qué opinaban, en especial a Ismael, le preguntó si quería trabajar en su propuesta, él respondió: "no profe, no importa, si quieren hagamos la de Soraida que está más completa". Les preguntó a los demás y todos parecían estar de acuerdo. La profesora Paz, les explicó que ahora debían conformarse un grupo de guionistas que trabajaran junto con Soraida para escribir el guión, se sumaron cuatro chicas más y se delegaron tareas y responsabilidades para avanzar con este tema.

Esta especie de libertad y autonomía otorgada a los jóvenes, da cuenta de la propuesta metodológica de las clases de cine, a diferencia de la mayoría de las materias tradicionales de la escuela, en donde el protagonista es el docente; lo que propone CineZap es poner en primer lugar las opiniones y decisiones de los jóvenes. Saben que esta historia no será calificada como los trabajos que suelen presentar en la escuela, sino que la misma será grabada y será compartida con otros jóvenes de su escuela y de otras escuelas. Al respecto Gauna afirma:

"No es lo mismo contar una historia para que la corrija un profesor, para que termine cajoneada y numéricamente "tasada" por un docente, que contarla para publicarla, destinada para un público, es decir para que la re-conozcan todos en el barrio, para que se muestre en otras escuelas, o para que se exponga junto a otras historias que también bregan por ser re-conocidas." (Gauna, 2014, p.10)

La propuesta pedagógica que aplican los docentes de CineZap, analizada desde la perspectiva del campo comunicación/educación invita a los jóvenes a ser autónomos y a ser partícipes de un proceso de aprendizaje que les posiciona en el lugar de autores de sus propios discursos. 
"Aprender hoy exige la construcción de tiempos y espacios que permitan el trabajo autónomo y cooperativo entre los alumnos, la investigación independiente y la discusión de resultados y hallazgos. Exige un docente capaz de articular un grupo heterogéneo en los ritmos y modos de solucionar las problemáticas cognitivas que se le presentan." (Tiramonti, 2011, p.162)

Pero además del rol que se propone a los estudiantes, esta práctica exige a su vez una predisposición por parte de los docentes, lo que facilite y promueva un proceso aprendizaje transformador (Huergo, 1997), una reconfiguración de los procesos educativos y de la concepción de la escuela en la actualidad.

\subsection{Escena 21 - Int - día - El cortometraje: qué se cuenta y cómo se cuenta}

Para la elección de los cargos para la realización del cortometraje, Lisandro les explicó los roles y responsabilidades de cada área. Cuando se fue a definir del cargo de director, nadie se postuló, una de las chicas guionista postuló a Soraida, la creadora de la historia, dice: "que la directora sea Soraida, que es la que sabe bien la historia", los docentes preguntaronn al resto del grupo y todos estuvieron de acuerdo.

Lisandro continuó explicando los demás cargos como iluminación, vestuario y maquillaje, camarógrafos y sonidistas. Para cada cargo se eligieron por votación 2 o 3 chicos por área, hasta que al finalizar todos tuvieron asignada una responsabilidad para la grabación.

Con los cargos definidos Lisandro propuso dividir el grupo, que las chicas encargadas de escribir el guión se quedaran en el aula trabajando en la escritura de la historia. Y con el resto de los chicos propuso hacer un ensayo o simulacro de una de las escenas de la historia, los chicos eligieron el 
final, donde la protagonista es asesinada. Así que Lisandro salió del aula con los chicos para llevar a cabo el ejercicio.

Por otro lado, yo me quedé trabajando con las chicas de guión que había avanzado con ayuda de la profesora Paz. La historia empieza con Killian, un hombre de 18 años que camina por una calle, se detiene frente a un galpón, está nervioso; allí en flash back, es decir en un salto temporal al pasado en forma de recuerdo, vemos a Killian de 9 años en la casa donde creció, está con su padre quien lo golpea brutalmente, Él huye a su cuarto llorando, en eso llega Lauren, su mejor amiga, una chica también de 9 años quien lo consuela.

Después vemos a Killian y a Lauren ahora de 15 años, ambos juegan a la pelota frente a la casa de Killian, llega el padre muy agresivo y golpeándolo lo hace entrar a casa. Se alternan las imágenes de Killian de 18 años entrando al galpón, de la misma escena del principio. Regresamos a la adolescencia, Lauren corre asustada a su casa y busca un arma, regresa con Killian, pero el padre al ver el arma forcejea con Lauren, Killian asustado agarra el arma y dispara a su padre. Pasa el tiempo y vemos a Killian en un orfanato donde Lauren lo visita varias veces, pero en una ocasión llega a visitarlo y está embarazada, Killian se muestra celoso.

Ahora vemos a Killian de 18 años saliendo del orfanato y regresando a la casa donde creció Lauren, toca a la puerta y Lauren lo recibe. En la siguiente escena vemos a los protagonistas en una habitación llena de cosas para bebe, Lauren está muy alterada, le cuenta que a su bebé lo asesinaron y quiere justicia. Le cuenta que ha intentado varias veces matar al asesino de su hijo pero no lo ha logrado, y que ahora tiene un plan que no puede fallar, ya lo ha citado en un galpón y se verá con él a la noche siguiente y ahí lo matará, le muestra un arma. Killian alterado intenta persuadirla de que no lo haga, pero ella se muestra inflexible; decidido Killian le quita el arma de las manos y le dice que no va a permitir que ella arruine su vida, que él se va a hacer cargo de eso, cuando le saca el arma de las manos vemos su muñeca y brazo con varias cortadas de intentos de suicidio. 
Continúa la primera escena, Killian ha entrado al galpón y saca el arma, camina hacia un balcón, se escucha la voz de Lauren contándole cómo es el lugar donde citó al asesino y que siempre lleva una ropa en particular, ve de espaldas la silueta que le describió Lauren, nervioso decide disparar. El cuerpo cae, Killian se acerca y se sorprende al ver el rostro de Lauren con el maquillaje corrido por las lágrimas, en sus manos lleva una nota, se escucha la voz en off de Lauren contándole que ella fue quien accidentalmente asesinó a su bebé.

Cuando llegamos a esta parte de la historia surgen varias opciones acerca del final de Killian, una chica propuso que la historia terminara allí, otra que él agarre el arma y se suicide, y otra chica que se vea que agarra el arma y que quede en suspenso el final. Debatieron pero no llegaron a un acuerdo; yo les propuse que lo compartieramos con el resto del grupo a ver qué opinaban. Soraida se levantó y llamó la atención de sus compañeros, empezó a hablar pero no se entendió bien la idea, así que yo hice un breve recuento de la historia y les dije las opciones propuestas para el final, la primera respuesta de una de las chicas fue: "que se mate, eso, ique mueran todos!" ante lo cual varios se mostraron de acuerdo. Otra chica dijo que prefería el final abierto, que no se sepa que pasa con él, hablaban al tiempo y se dispersaban.

Lisandro se acercó al grupo de guionistas y la profesora Paz se sumó, entre todos repasamos las opciones y todas parecían viables, pero no había consenso; yo les propuse analizarlo desde pensar el mensaje que se está transmitiendo, les pregunté qué es lo que querían contarle al espectador, qué es lo que querían que el espectador pensara al ver el cortometraje, hubo silencio y nadie opinó. Lisandro retomó diciendo que todas las opciones eran buenas y que a él le gustaba la del final abierto. En eso, Milagros, una de las chicas que hacía parte del grupo de camarógrafos, que siempre se mostraba rebelde ante lo que decían los profesores, se levantó con la mochila puesta y dijo que ya eran las seis de la tarde y abrió la puerta del salón; la profesora Paz le pidió que esperara, ya que el timbre no había sonado, ella argumentó que todos estaban saliendo. A esto los demás chicos terminaban de guardar sus cosas y se preparaban para salir, Milagros y un par más salieron del salón, haciendo caso omiso a las indicaciones de la docente. 
De las acciones descritas anteriormente, se pueden resaltar las actitudes tomadas por los jóvenes que participaban, cuando se les pidió consenso acerca del final de la historia prevaleció el deseo

por la muerte de los personajes. Si bien era parte de la idea original del cuento, los jóvenes no comentaron otra alternativa al hecho de la muerte de la protagonista e incluso deseaban que el personaje del asesino muriera también. Los comentarios parecían impulsivos y sin mayores argumentos, pero denotan que la solución más fácil y rápida es la muerte. Frente a las temáticas que se abordan en los cortometrajes, Luna comenta:

"Uno de los objetivos del proyecto es que los alumnos desarrollen su expresividad. Por eso, nos situamos en la propuesta en el lugar de escucha. Ante la finalidad expresiva no buscamos un resultado en torno a una temática en particular ni homogeneidad en los asuntos de las narraciones, sino que, por el contrario, propiciamos la diversidad: ¿Qué tienen para decirnos nuestros jóvenes? ¿Qué historias quieren contar? El valor está puesto en su discurso, en sus intereses, en sus puntos de vista. Buscamos resultados idiosincrásicos, no la repetición de opiniones o juicios condicionados." (Luna, 2012, p.210)

Para Luna, la visión que tiene CineZap, frente a temas como la muerte o la violencia, no es una mirada prejuiciosa o estereotipada, para ella, las clases de cine, son un espacio alternativo dentro de la escuela, que les permite reflexionar sobre lo que quieren contar los jóvenes. En el caso de la historia de Soraida, deja entrever una preocupación o el deseo de abordar el tema de la muerte.

\subsection{Escena 22 - Int - día - Reconstrucción de realidades}

A partir de la experiencia de construcción de las historias y del guión, quiero profundizar en algunos aspectos que sobresalen de estas anécdotas. Inicialmente analizo la manera en que se relacionan estas narraciones con el contexto socio-cultural y las vivencias de los jóvenes que participaron del programa CineZap. 
Para el caso de esta escuela, la construcción de la historia de ficción podría relacionarse más con el contexto social del barrio en el cual está ubicada esta escuela. La joven que escribió el cuento seleccionado, plasmó una preocupación por la vida y por la muerte, por ese aparente final al que todos están destinados de una u otra manera. Los estudiantes de este grupo, se manifestaron con marcada naturalidad ante la idea de que la muerte no sólo es el único final posible, sino también el mejor o el más común.

Durante conversaciones informales con los chicos, escuché a varios de ellos comentar, que a algún conocido lo habían matado por vender drogas, por robar o por "andar con malas amistades", incluso en algunos casos, parecían afirmarlo con gran naturalidad, como si esto no fuera algo extraordinario. Esto podría relacionarse a su vez, con la idea de pagar por asesinar, es una idea con la que conviven frecuentemente por reconocerla en casos de amigos, conocidos o vecinos.

Duschatzky documenta situaciones similares en otras escuelas medias de la ciudad y al respecto comenta:

"En los barrios del conurbano la problemática de la droga se revela en todo su dramaticidad. Por un lado la esfera doméstica aparece comprometida en la comercialización de la droga sin ningún tipo de ocultamiento. Por el otro el consumo impacta directamente en los vínculos generacionales, la mayoría de los chicos que consumen roban para conseguir la droga, despertando en los adultos un sentimiento de hostilidad y de desconfianza. Cada vez más el consumo aparece asociado a un deterioro de la calidad de vida: la mayoría de los jóvenes que más consume no trabaja, abandonó la escuela y revela una vitalidad deteriorada.” (Duschatzky, 1999, p.9)

Si bien, en este caso, el tema central no es la droga, sino la muerte y el asesinato, así como para Duschatzky la droga permea los diferentes ámbitos donde los jóvenes se desenvuelven, lo mismo 
sucede con la idea de la muerte en las historias de los jóvenes de esta escuela. De igual manera han construido con gran naturalidad la idea de que la joven a su corta edad, 16 años aproximadamente, haya quedado embarazada y sea madre soltera. Como comenté anteriormente, en este grupo había una chica que estaba embarazada y otro chico que cuidaba a su hijo durante las clases, también se sabía de casos de embarazos en otros grados de la escuela. Es decir, este es un aspecto que ellos habían naturalizado y lo contemplaban como un accionar común y recurrente.

\subsection{Escena 23- Int - día - La grabación, Día 1, tensiones de poder}

Después de realizado el proceso de pre-producción, se acordó llevar a cabo la grabación de las escenas los días 5 y 6 de octubre. El primer día, llegué al punto acordado, una plaza grande cerca de la escuela y los chicos ya habían empezado la grabación de las escenas.

Todo el grupo estaba reunido en una esquina de la plaza, se disponían a grabar la escena donde la joven va a cruzar una calle con el cochecito del bebé y por una distracción suya un auto atropella el cochecito y el bebé muere. Lisandro estaba dentro de su auto, éste era el que iban a usar para la escena. Al llegar los saludé a todos, vi que había dos jóvenes que no conocía, los saludé también y me dijeron que eran pasantes de la FUC, se llamaban Jean Franco y Luis, ese día ayudarían en la grabación.

Grabaron un par de tomas, pero se les dificultaba coordinar entre el semáforo, Lisandro pasando con el auto y que el cochecito bajara justo cuando pasaba el auto. Noté que un par de chicas, Andrea la encargada de la claqueta y Sonia la asistente de dirección, se veían estresadas porque no logran grabar la escena.

Crucé de nuevo la calle y vi cómo grababan dos tomas más, al ver que no salían como ellos esperaban, se reunieron Soraida, la directora del cortometraje, que es la misma chica que escribió 
la historia, los dos pasantes de la FUC y Mary la camarógrafa. Soraida estaba estresada y evadía la conversación, miraba para otro lado y se le veía molesta, al final lograron llegar a un acuerdo y decidieron grabar de nuevo la escena. Se grabaron dos o tres tomas más, hasta que se mostraron satisfechos. Cuando lo lograron todos aplaudieron.

De repente volteé a mirar y estaba Cristian Gauna, el coordinador del proyecto, lo saludé, cruzamos un par de palabras y yo me involucré de nuevo con los chicos. Pasamos al siguiente plano, Jean Franco discutió con Soraida sobre qué es lo que querían mostrar, era el plano de la reacción de la protagonista cuando el cochecito cae. Se pusieron de acuerdo y Mary acomodó la cámara, todo el equipo se desplazó hacia esa esquina, Soraida le dió algunas indicaciones a la protagonista y grabaron una toma, la chica estaba nerviosa con todos a su alrededor y se reía; a la chica se le dificultaba, siempre sonreía y debía mostrarse angustiada. Soraida le propuso que se agarrara la cara y ensayaron diferentes posibilidades de reacción, grabaron varias tomas hasta que al final consiguieron una que le convenció a la directora.

A las 5:30 pm, terminaron de grabar las últimas escenas del día así, todos aplaudieron y Lisandro pidió que fuéramos todos a la plaza donde estaban tres de las chicas del grupo, quienes se encargaban de cuidar algunos bolsos, mochilas y pertenencias del grupo. Llegamos allí y estaban también las profesoras Paz y Liliana. Todos los chicos se sentaron en el pasto, mientras las profesoras les repartían unas viandas que consistían en: sándwiches, agua, gaseosa y alfajores.

Lisandro los felicitó por el trabajo del día y luego dió algunas indicaciones para la jornada siguiente, les recordó que el punto de encuentro sería en la escuela a las 9 am. También pidió que revisaran los elementos necesarios para la grabación del día siguiente: una pistola de juguete, velas, fotos de bebé y juguetes para la habitación del bebé. Con respecto al vestuario Luis, uno de los pasantes, sacó un papel y le indicó a la protagonista lo que con el departamento de arte habían planeado que debía llevar puesto en las escenas faltantes, le pidió que trajera dos cambios de ropa. Los demás escuchaban e iban guardando los equipos, algunos comían y bebían gaseosa y agua. Los chicos y las profes se despidieron y se dirigieron de nuevo a la escuela. 
Nos quedamos unos minutos Lisandro, Cristian, Luis, Jean Franco y yo hablando, primero hablamos sobre porqué las tres chicas estaban apartadas, al parecer existía una tensión entre la asistente de la directora y una de las chicas que estaba apartada. Lisandro comentó que una de estas chicas le dijo que Soraida no soporta que ella participara más o que le daba envidia que ella fuera más bonita, el caso es que siempre que estaban juntas había mucha tensión porque cada una quería hacerse notar más que la otra.

Lisandro también habló sobre la elección de los actores, comentó que un par de semanas atrás había llegado un chico nuevo que estaba en la jornada de la mañana y lo pasaron a la tarde, que al parecer quería actuar en el corto. El día de la elección del protagonista estaban como opciones el chico nuevo e Ismael, Ismael al principio de las clases se mostraba muy alejado y poco interesado pero cuando propusimos que escribieran las historias empezó a interesarse más y desde entonces se le veía más animado y participativo, Ismael también se había postulado para actuar en el corto. El día que se hicieron las votaciones para elegir al actor el chico nuevo ganó rotundamente, con aproximadamente 13 votos de 15, pero ese mismo día a la tarde el chico nuevo tuvo una pelea y al día siguiente no llegó a clase, la grabación era dos días después así que en último momento se decidió que Ismael, por descarte, debía actuar.

Según Lisandro esta decisión también generó malestar entre algunas de las chicas del grupo, en especial en Soraida y Sonia, la asistente de dirección; quienes lo presionaban y le decían malas palabras, porque según ellas no actuaba bien, era muy lento y dormido. Jean Franco comentó también que, ante esta situación, de manera discreta él le dijo a Soraida, la directora, que ella era la única que podía motivarlo para que saliera bien, que fuera más tolerante y le hablara bien.

Luego de eso Cristina habló un poco sobre el clima, había pronóstico de lluvia en la tarde y por suerte hasta ese momento, 5:30 pm aprox, no había llovido. También dijo que estaba visitando todos los rodajes, porque había escuchado muchos comentarios de que las cosas en los barrios estaban muy pesadas. Yo no entendí muy bien a qué se refería, ante eso Lisandro dijo que ahí en 
el barrio y en la escuela había mucha tensión por el caso del chico de la "Garganta", ¿la que? pregunté yo, Cristian nos preguntó si conocíamos el colectivo "Garganta Poderosa", a lo cual respondimos que no. Nos contó que es un colectivo creado en la villa en respuesta a la violencia y represión de las fuerzas del estado en aquellos barrios, se encargaban de denunciar y apoyar los casos de abuso.

Al parecer esa semana un chico de la villa, que en una ocasión anterior había sido víctima y había visto cómo a uno de sus amigos, agentes de la Policía Federal lo habían torturado, obligado a cruzar el riachuelo y el chico murió; esta vez se enfrentó a un grupo de la policía federal que estaban agrediendo a otro joven y les gritaba que él sabía lo que habían hecho, que ellos habían matado a su amigo, ante esto los agentes lo reprimieron y golpearon también. Por ese motivo el colectivo "Garganta Poderosa", los profesores de la escuela y algunos vecinos del barrio estaban molestos por la situación y había mucha tensión con la Policía Federal en el barrio.

Esta anécdota narrada por Cristian da cuenta de la interrelación que se da entre la escuela y el barrio, entre los jóvenes las familias y los vecinos. En este caso la escuela viene a aparecer como el punto de encuentro, donde convergen las diferentes experiencias y preocupaciones tanto de los jóvenes, como de los docentes, familiares y vecinos, se eliminan las barreras físicas y simbólicas de la escuela y se entretejen acciones que adquieren una connotación comunitaria.

Duschatzky también observa esta ruptura de los límites físicos y simbólicos en otros casos de escuelas medias y afirma:

"La escuela se perfila aquí como el pasaje, como la posibilidad de otra representación. La escuela como "frontera" supera los límites estrechos de su territorialidad. La frontera en este caso es pensada en el cruce de territorios o ámbitos de experiencia y, como tal, más que un coto designa un tránsito, una posibilidad. Desde aquí la escuela como frontera no niega otros espacios, otros saberes, otras lógicas de aproximarnos a 
la realidad, otras instituciones sino que es el lugar del intercambio, y de la disputa entre lo familiar y lo ajeno.” (Duschatzky, 1999, p.13)

Desde el campo comunicación/educación, esta idea de re configuración de los límites y fronteras de la escuela, es planteada como una de las estrategias que promueven la transformación (Huergo, 2007). Dentro de este marco de ideas, el programa CineZap, viene a ser una de las tantas acciones interpeladoras que se realizan en esta escuela, pero no es la única; organizaciones barriales donde participan docentes, movilizaciones donde participan vecinos y estudiantes y otras acciones, demuestran que la escuela, en este caso, es un punto de encuentro donde se discuten, se reconocen y se gestan iniciativas comunitarias.

Esa tarde Cristian Gauna se ofreció a llevarme en el auto, allí habló sobre el programa CineZap, decía que la cuestión administrativa estaba cada vez peor, que esta situación venía desde la administración pasada pero que con la actual las cosas había empeorado. Desde el sector de educación del Gobierno de la Ciudad les apoyaban cada vez menos, según él, los de la administración no entendían qué se hacía en el programa y por ello no le prestaban la atención necesaria, que les propusieron unirse a un programa que ofrece clases a los chicos en contra jornada, ellos aceptaron pero como un agregado del proyecto CineZap.

Cristian comentó que si bien desde la administración no querían sacarlos del todo, porque sentían que se hacía algo interesante, aunque no entendían que. El problema era que ante cualquier solicitud para mejorar se mostraban reacios, incluso, decía que los requerimientos logísticos básicos que siempre solicitaban para las jornadas de rodaje en cada escuela, se veían afectados por la ineptitud de los encargados de estas áreas. Expresó gran malestar ante este tipo de situaciones y culpaba a los funcionarios del ministerio. 


\subsection{Escena 24 - Int - día - La grabación, Día 2, autonomía y empoderamiento}

El segundo día la grabación se realizó en una casa creada por colectivos barriales, profesores de la escuela y gente del barrio, la casa llevaba por nombre: "Decir es poder". Allí se realizaban alfabetizaciones con adultos y otras actividades culturales; ésta casa estaba ubicada dentro de la villa, así que uno de los chicos debía ir por mí a la escuela para llevarme hasta el lugar. Estaba esperando en la puerta de la escuela y a los pocos minutos llegó un grupo de unas 15 personas, llevaban chalecos que decían CTERA, así que asumí que pertenecían al gremio de los profesores, estaban esperando a que salieran algunas personas de la escuela según escuché.

A los 5 minutos aproximadamente vi a media cuadra a la profesora Paz que me llamaba con la mano y caminaba apurada, una de las personas de chaleco de CTERA le decía a Paz que iban saliendo, ella le gritó que me dejaba a mí en la grabación y regresaba junto con la profesora Liliana, que la esperaran 5 minutos. Empezamos a caminar muy apuradas casi corriendo, le pregunté si salían a alguna marcha, Paz me respondió que por el caso del chico que los agentes de la Policía Federal habían golpeado y amenazado iban a salir a marchar, recordé que Lisandro el día anterior, nos había comentado la situación. Iban profesores, estudiantes de la escuela y vecinos del barrio.

Caminamos apuradas por una de las calles principales, sobre la misma que quedaba la escuela, luego giramos por una calle sin pavimentar y giramos de nuevo hacia un callejón. Un par de hombres de unos 25 años nos miraban fijamente y algo comentaron, pero no les escuché, caminé más rápido. A mitad del callejón estaba la casa de "Decir es poder"

Al entrar a la casa había una sala con algunas mesas, sillas para niños y una biblioteca muy modesta; siguiendo por un pasillo corto había un pequeño comedor y una cocina improvisada. Saludé a los chicos, dejé mis cosas sobre la mesa del comedor y me asomé hacia el fondo, había una pequeña habitación. En la puerta estaban Mary con la cámara, Soraida la directora, dos chicos de sonido y 
Jean Franco; dentro de la habitación estaba Ismael el protagonista y un hombre muy robusto, estaban grabando la escena en donde el padre del protagonista lo golpea fuertemente.

Sonia y Andrea, estaban de mal humor, les pregunté qué pasaba y me contestaron: Cambiaron una escena que no tiene sentido, ¿Por qué? ¿Cuál escena? pregunté, Ismael mata al padre pero ya está grande, si es así no se entiende por qué va después al orfanato, respondió Sonia, Andrea la apoyaba. Vamos a revisar, les respondí agarrando un guión que estaba sobre la mesa. En eso se acercó Lisandro que estaba en la habitación y lo saludé, él ya había escuchado la conversación y les preguntó qué pasaba, Sonia respondió: Aquí hacen lo que se les dá la gana, cambian las cosas sin sentido... eso no se va a entender, Lisandro les preguntó por qué pensaban eso, Andrea respondió: Porque ahora Ismael mata al padre ya grande, entonces no tiene sentido que grande vaya al orfanato. Lisandro les respondió que podía funcionar, que va al orfanato antes de los $18 \mathrm{y}$ al salir no han pasado años sino meses cuando cumple los 18 años y sale; esto no pareció convencerlas, seguían molestas.

Yo saqué mi cámara para sacar fotos y grabar, en eso Sonia se me acercó, agarró mi cámara de la mesa y me dijo: Yo quiero una cámara así, le respondí: ¿Te gusta? ¿te gustaría aprender a sacar fotos?, ¡Si claro! me respondió. Me devolvió la cámara, A ver, agarrala, le dije y le entregué la cámara. Le mostré cómo encenderla, la puse en modo automático y le expliqué rápidamente como sacar fotos. Entendió muy rápido la idea y empezó a sacarle fotos a las chicas que estaban sentadas en un banco largo frente a nosotras mirando un celular, ellas hacían poses para que Sonia les saque fotos. Luego fue hacia la habitación donde estaban grabando para sacar más fotos. Observandola me dí cuenta que le cambió completamente la expresión, pasó de estar enojada a mostrarse muy motivada.

Intenté acercarme a la habitación donde estaban grabando, pero el espacio era muy reducido y no pude pasar. Fui hacia la sala a ver qué hacían los demás chicos, había un par de niñas pequeñas, una de ellas era la hermana de Sonia, quien iba a representar el papel de la protagonista cuando es niña, tiene 8 años aproximadamente. La otra niña era más chica, unos 6 años aproximadamente, 
era la sobrina de uno de los chicos que llevaba las planillas y la claqueta. Un par hablaban en las sillas y la niña más chica dibujaba en un tablero con tiza, una de las chicas que hacía sonido el día anterior estaba con ella dibujando.

A los pocos minutos, salieron de la habitación diciendo que habían terminado de grabar esa escena. El hombre robusto salió y se despidió con la mano, iba un poco apurado; por lo que escuché, era un profesor de la escuela que se ofreció a ayudarles a interpretar el papel del padre del protagonista. Les pregunté qué escena continuaba, seguía una donde la protagonista de niña observa por la ventana cómo el padre le pega al chico; esto se iba a grabar en esa sala usando la ventana que daba a la calle. Llevaron los equipos, mientras Jean Franco y Soraida planeaban cómo debía ir el plano. Mary acomodó la cámara, Sonia le daba indicaciones a su hermana de lo que debía hacer, ella debe estar afuera de la ventana y mirar.

Grabaron la escena de la niña mirando por la ventana, pero debieron hacer varias tomas, por la expresión de la niña o por la velocidad y la acción de acercarse y alejarse de la ventana. Sonia insistía en que no se burlaran, ya que su hermana era muy sensible y si se enojaba les iba a ayudar más. Los demás la motivaban y al lograr la toma aplaudieron todos. Luego de eso se grabó una acción similar, pero con la protagonista de grande, la chica que la representaba, ensayó varias veces con las indicaciones de Soraida.

Los chicos de sonido querían salir a la calle para capturar el sonido de los pasos de la chica, pero Lisandro se mostró preocupado y les sugirió que lo hicieran desde adentro, para que no se exponerse a que les robaran los equipos. En la realización de esta escena, Sonia salió varias veces al frente de la calle y a la segunda vez, me devuelve la cámara de fotos diciendo: mejor se la doy, mirá si van y me la roban, refiriéndose a que era peligroso salir a la calle con este tipo de elementos. Los chicos conocen la zona y saben que no deben exponerse con aparatos costosos y/o llamativos, ya que corren el riesgo de que los roben. 
Al terminar de grabar esta escena todos aplaudieron de nuevo, se preguntaban entre ellos y Lisandro y Soraida confirmaban que ya había grabado todas las escenas. Eran las 5 de la tarde, fuí hacia la cocina y pedí a los chicos que estaban allí que organizáramos el lugar. Al terminar, Lisandro pidió que saliéramos todos juntos para evitar cualquier tipo de inconveniente relacionado con la inseguridad del lugar.

\subsection{Escena 25 - Int - día - La edición, el cortometraje finalizado}

Al terminar la grabación de las escenas, Lisandro y las profesores de la escuela organizaron para realizar la edición del cortometraje, esto se realizó en las instalaciones de la FUC. Se coordinó el traslado de un grupo de 4 chicos: la directora, la actriz principal y dos chicos más del grupo, en compañía de una de las profesoras y de Lisandro. En las instalaciones de la FUC les reservaron un salón y asignaron a tres practicantes de la FUC para ayudarles en la edición final del cortometraje.

Durante el proceso de edición, los chicos vieron cómo iba quedando la historia, pero discutían entre ellos y Lisandro, que quizá la historia no quedaba tan clara, que no se entendía muy bien la motivación o la razón de porque Killian, el personaje principal termina asesinando a la protagonista. Lo hablaron entre ellos y decidieron agregar una voz en off de Killian, es decir que mientras se ve al personaje, de fondo se escuche su voz. Lo agregaron y el cortometraje empieza de la siguiente manera:

Se ve a Killian, un joven de aproximadamente 17 años, caminando por una calle, lleva sobre su cabeza la capucha de su campera. Se le ve indeciso y suena de fondo su voz diciendo: ¿por qué a mí?. Luego, en flash back, es decir en un salto al pasado, se ve a Killian de 8 años aproximadamente, está en una habitación jugando con unos autitos, suena su voz de fondo: de niño deseaba ser feliz, pero tenía una vida miserable; luego entra el padre, un hombre grande y robusto quien empieza a golpearlo violentamente. 
Posteriormente se desarrolla la historia tal cual la habían escrito en el guión, y se agregan en un par de escenas la voz del protagonista narrando sus pensamientos.

Desde que empieza el cortometraje, los jóvenes de esta escuela exponen una problemática que evidencia la constante presencia de la violencia en su vida cotidiana, violencia que toma diferentes formas y contextos conforme la historia avanza. La escena inicial donde un padre golpea a su hijo, el deseo de la protagonista por asesinar al padre de Killian, la posterior materialización de este deseo pero en manos del propio Killian; el hecho de que el hijo de Lauren, la protagonista, ha muerto y el final de la historia que termina con la muerte de la protagonista.

Esta sucesión de muertes y de actos violentos, dejan sentado que es una problemática que les afecta directamente, no solamente proviene de referentes vistos en medios de comunicación como la televisión, sino que posiblemente han vivido o conocen casos cercanos donde la violencia y el asesinato son una constante en sus anécdotas.

"Es evidente que a los jóvenes la realidad cotidiana les pesa, les preocupa y quieren intervenir modificándola. Cuando tienen la oportunidad de hablar sobre algo eligen hablar de ella y con un sentido comprometido. Las inquietudes humanitarias que trasuntan sus miradas son muy alentadoras y ejemplificadoras para una sociedad que suele tildarlos de superficiales y descomprometidos. De esta manera, los videos, las producciones audiovisuales, se convierten en un lugar de encuentro social en donde los jóvenes sistematizan sus miradas, se acercan entre ellos y permiten acercarnos a ellos compartiendo el trabajo y comprendiendo sus configuraciones narrativas." (Luna, 2012, p.215)

Luna documenta y reitera, una vez más, el carácter catalizador que tienen las clases de CineZap para los jóvenes de las escuelas donde se desarrolla el programa. La experiencia de plantear en una historia de ficción, las problemáticas que les preocupan, es una reafirmación del carácter reflexivo 
y transformador de esta práctica. Para el caso de esta investigación, y dentro del campo comunicación/educación esto representan una reivindicación del deseo de construir nuevos caminos y formas que transformen las dinámicas educativas dentro y fuera de la escuela.

Como suele hacerlo año tras años, CineZap organiza un evento de cierre al finalizar el año lectivo, donde se invitan a los participantes de todas las escuelas y se realiza la proyección de los cortometrajes realizados, pero debido a temas personales y laborales me fue imposible asistir a este evento.

\subsection{Escena 26 - Int - día - El reconocimiento del mundo cultural y la resignificación de las fronteras}

La experiencia de exploración narrativa y posterior realización audiovisual de este grupo, se caracteriza por la materialización de algunas construcciones colectivas. Las diferentes propuestas temáticas iniciales y la escritura final del guión, revelan algunas preocupaciones del ámbito social de este grupo; aspectos como el embarazo en adolescentes, la violencia intrafamiliar y el asesinato, son problemáticas enunciadas de manera constante durante todo el proceso.

En contraste con el deseo expresado tanto por el docente de cine como por los coordinadores de CineZap, de promover en estos procesos de creación narrativa, una mirada alternativa ante la fatalidad, la muerte y la violencia, se ve sobrepasado por las propuestas de los jóvenes. Aunque evidencié una invitación constante a reflexionar al respecto, todas las miradas y propuestas que nacían de los estudiantes tenían esta impronta. Pero como lo menciona Huergo, las prácticas de comunicación/educación, implican un reconocimiento del mundo cultural de los sujetos (Huergo, 2007), la realidad que rodea a estos jóvenes y la presencia constante de estas problemáticas, es tan latente en ellos, que inevitablemente, cuando se les presenta la oportunidad de hablar de ella, de narrarla y de visibilizarla en un cortometraje, estas son las temáticas que los jóvenes deciden tratar. 
Por otro lado, de la experiencia de esta escuela, sobresale también el concepto de resignificación de las fronteras de la escuela, como Duschatsky lo menciona, este tipo de intervenciones promueven una ampliación de los límites físicos de la escuela. Los procesos de aprendizaje no solamente se vivencian dentro del aula, salir a grabar en una plaza, en una calle, en la casa de los estudiantes u otros espacios, también hacen parte de la práctica educativa.

De igual manera, se vive una ampliación de las fronteras no solamente dentro de una concepción espacial o territorial, se genera una apertura dentro de la comunidad que participa de la experiencia. Los jóvenes no son el único público objetivo de las prácticas, docentes, directivos, familiares y miembros de colectivos barriales, se involucran de diferentes maneras. Invitando a reflexionar sobre las construcciones colectivas del aprendizaje, donde todo aquel que quiera participar es bienvenido y donde los estudiantes entienden que se requiere de determinada voluntad y autonomía para que ésta pueda ser llevada a cabo. 


\section{CONCLUSIONES}

La anterior reconstrucción de las experiencias del programa CineZap en estas dos escuelas, es una interpretación personal de las vivencias, de las opiniones y comentarios de los cuales fui testigo. A partir de ello, y por las licencias de una construcción etnográfica, puse la mirada en los procesos (Luna, 2012) y posicionada desde las perspectivas analizadas dentro de la maestría, construí un entramado de voces y miradas. Un trabajo artesanal que pretendió a punta de hilo y puntada, hacer que convergieran en este texto, reflexiones que directa e indirectamente constituyen un aporte para el campo comunicación / educación.

Es por ello, que a manera de conclusión, a continuación recopilo algunas reflexiones finales acerca de las tensiones, transformaciones y reconfiguraciones analizadas en esta investigación.

Quisiera empezar por hablar acerca de las tensiones, desde una perspectiva de comunicación/educación, tensiones entre lo institucional y no institucional, entre la práctica y la teoría, entre los roles de poder, entre las relaciones docente-alumno y entre las fronteras materiales e imaginarias que fueron evidenciadas durante este proceso. Como lo mencionan Escobar, Gauna, González y Morabes, la postura del programa CineZap, propone repensar y reorganizar por completo las lógicas dentro del aula, redefinir objetivos centrales, contenidos curriculares, estrategias didácticas y refundar el vínculo docente-alumno. (Escobar, Gauna, González y Morabes, 2012).

En las experiencias de las dos escuelas, la intervención de CineZap, representó para los estudiantes y para los docentes un ir y venir entre la rigidez y la flexibilidad de una dinámica interpeladora. En ambos casos, los participantes vivieron situaciones donde se puso en juego y se cuestionaron estas tensiones, dejando entre ver que prácticas como las de CineZap, promueven procesos de transformación, que median entre el pesado legado de la estructura tradicionalista de la escuela y 
la imperante necesidad de continuar promoviendo procesos de aprendizaje donde se reconozcan y se reflexione acerca de estos paradigmas.

Esta voluntad de transformación enunciada por los integrantes de CineZap, y puesta en tensión en la práctica en estas dos escuelas, implica necesariamente un reconocimiento del mundo cultural de los sujetos (Huergo, 2017), aspecto que los docentes de cine consiguen al involucrarse de manera constante y consciente en los procesos de cada escuela. En ambos casos, fui testigo de la voluntad y compromiso de estos dos docentes de cine, no sólo con su rol dentro del programa de CineZap, sino con su interés por las preocupaciones de los docentes, de los estudiantes y de la escuela. Procurando hacer de esta intervención, una oportunidad para desnaturalizar prácticas hegemónicas, para interpelar a los participantes y para promover cambios en la manera de concebir hoy en día los procesos comunicativos y educativos.

Otro aspecto que promueve el programa CineZap es el empoderamiento de los jóvenes, al invitarles a que sean autores de sus propios relatos. En el caso de la escuela de Educación Media No 6 Distrito Escolar 5, este punto se ve reforzado en los diferentes momentos que vivieron los estudiantes, durante la construcción de la historia y posterior grabación y edición del cortometraje. Los jóvenes tuvieron la autonomía de tomar decisiones narrativas y estéticas; tanto el docente de cine como las docentes de la escuela, propiciaban constantemente la libertad de definir los personajes, las situaciones y los roles de cada participante.

En el caso de la escuela Técnica Número 17 Brigadier General Don Cornelio de Saavedra, el empoderamiento y autonomía se vio disputado en un par de situaciones, como durante la elección del nombre de los personajes o en la etapa de grabación cuando los estudiantes manifestaron la intención de modificar una de las escenas; momentos en que la docente de la escuela se impuso y de alguna manera coartó las propuestas de los jóvenes. Esto pone en tensión dos de las premisas del programa CineZap: la reconfiguración de las relaciones alumno-docente y el empoderamiento de los jóvenes, relevando las estructuras de la educación tradicional, donde las jerarquías dentro 
del aula son marcadas, y si bien se les invita a los jóvenes a ser autores de sus historias, esa aparente libertad se ve mediada por la voluntad impositiva de la docente.

El análisis de las experiencias en estas dos escuelas, habla desde las particularidades de sus protagonistas, pero a su vez da cuenta de años de trabajo por parte del equipo de CineZap, de las escuelas, de los docentes, de la FUC y de todos aquellos que directa o indirectamente participan de las clases de cine y de los procesos de creación. Es un ejemplo de una práctica de comunicación/educación que pone en evidencia el camino abonado en el territorio latinoamericano, por parte de teóricos, pensadores, docentes, estudiantes, comunicadores y de todos aquellos que con sus aportes constituyen y enriquecen las reflexiones en torno a este campo.

Otro de los grandes aportes de CineZap, y el motivo por el cual elegí este programa como objeto de estudio, tiene que ver con la perspectiva, metodología y dinámicas de intervención que ellos promueven. Proponen pasar de las miradas reduccionistas del audiovisual como herramienta pedagógica (Huergo, 1997), para empezar a hablar de una práctica basada en la premisa del audiovisual como dispositivo de intervención (Gauna, 2014). Esto implica interpelar a la construcción colectiva en un ámbito que promueve las individualidades, como lo es la escuela tradicional, invitando a la resignificación y transformación de las prácticas, de las instituciones y de los paradigmas.

De esta manera la propuesta de CineZap, toma como base la invitación a construir una narración audiovisual de ficción, para promover procesos reflexivos entorno a la relación docente -alumno, como lo mencionaba anteriormente, en torno a las dinámicas educativas, a los tiempos y formas escolares, a la reconfiguración de las fronteras de la escuela, a la promoción de una mirada crítica frente a los medios de comunicación y a la manera en que nos relacionamos con ellos.

Es por ello que encuentro una relación directa entre la perspectiva de este programa y uno de los paradigmas principales trabajados en esta maestría, citando a Huergo: "al referirnos a Comunicación/Educación hacemos referencia a procesos y prácticas que se dan en los contextos 
de interrelación entre la cultura y la política. En este sentido, sería posible sostener que el objeto de este campo es la articulación entre formación de sujetos y producción de sentidos." (Huergo 1997, p.6).

Por último, quisiera proponer una reflexión acerca de la imaginación como motor de acción. Viendo en retrospectiva, todos los momentos y experiencias de las cuales fui participe en estas dos escuelas, y durante el proceso de escritura de esta tesis, aparece de manera constante en mis reflexiones esta idea, un poco romántica, de la imaginación como eje y propulsor. El equipo de CineZap imaginó y continúa imaginando una propuesta de intervención, los docentes imaginan un proceso transformador y los estudiantes imaginan una historia que se volverá realidad. Paulo Freire imaginó formas de aprendizaje alternativas, Jorge Huergo imaginó la materialización de un campo teórico - práctico llamado comunicación/educación. Así que me pregunto si quizá, como aporte al campo comunicación/educación, no tendríamos que darnos la oportunidad no solamente de reflexionar sobre las teorías y las prácticas, sino que a su vez podríamos propiciar espacios para reflexionar sobre la imaginación.

Entendiendo el campo comunicación/educación como un elemento vivo, que crece, muta y se nutre con las reflexiones de quienes nos identificamos con él, esta tesis pretende ser un aporte a la multiplicidad de miradas que lo componen, citando a Schmucler: "Comunicación/Educación no sólo puede entenderse como un objeto constituido, sino principalmente como un objetivo por lograr; objetivo que conjuga deseo e interés crítico, que da sentido a las prácticas. Y este deseo/interés, esta voluntad de transformación es típica en el pensamiento latinoamericano al vincular la teoría y la práctica con la ética y la política.” (Huergo 1997, p.11)

Teniendo en cuenta esto, y consciente de que a partir de esta maestría y de todas las reflexiones generadas en torno a ella, se seguirá construyendo uno o varios campos de acción, en donde programas, proyectos e ideas como las de CineZap, seguirán aportando en la teoría y en la práctica, para contribuir así al crecimiento y transformación de todos los procesos transgresores de Latinoamérica. 


\section{Bibliografía}

ARGUMEDO, Alcira. (2006). Los silencios y las voces en América Latina, Editorial Colihue

BARBERO, Jesús Martín. (1991). De los medios a las Mediaciones, Barcelona, Editorial Gustavo Gili

BARBERO, Jesús Martín. REY, Germán. (1999). Los ejercicios del ver, Gedisa, Barcelona

BORNEMANN, Elsa Isabel. (1994). Socorro!: 12 cuentos para caerse de miedo. México, Alfaguara

BOURDIEU, Pierre. (1991). El Sentido práctico. Madrid, Taurus

BRUNER, Jerome. (1997). La educación, puerta de la cultura. Madrid, Visor

BRUNER, Jerome. (2003). La fábrica de historias. Buenos Aires, Fondo de Cultura Económica

BUENFIL BURGOS, Rosa Nidia. (1992). "Consideraciones finales sobre lo educativo”, en El debate sobre el sujeto en el discurso marxista: Notas críticas sobre el reduccionismo de clase y educación. México, Tesis de Maestría, DIE-IPN

BUENFIL BURGOS, Rosa Nidia. (1993). Análisis de discurso y educación. México, DIE

CANCLINI, Néstor García. (2001). Culturas híbridas. Estrategias para entrar y salir de la modernidad, Colección: Estado y Sociedad, Paidós

CULLEN, Carlos. (2008). La construcción de un espacio público como alternativa a la violencia social en el contexto de la globalización en Feldfeber, Myriam, Los sentidos de lo público. Reflexiones desde el campo educativo. Buenos Aires, Novedades Educativas 
CULLEN, Carlos. (2009). La lucha por el reconocimiento como condición del diálogo educativo. Ponencia, Revista separata Vol 7, Num 14. Argentina

DE SOUZA SANTOS, Boaventura. (2010). Descolonizar el saber, reinventar el poder, Trilce Extensión Universitaria, Montevideo

DUSCHATZKY, Silvia y AGUIRRE, Elina. (2013). Des-Armando escuelas, Buenos Aires, Paidós

DUSCHATZKY, Silvia. (1999). La escuela como frontera. Reflexiones sobre la experiencia escolar de jóvenes de sectores populares. Paidós

ESCOBAR, Andrés; GAUNA, Christian; GONZALEZ Lisandro Ursi y MORABES, Fernando. (2012). "Hacer Cine, un dispositivo de intervención socioeducativa" ponencia escrita por Universidad Nacional de La Plata/ Universidad del Cine. Para el Congreso de Periodismo y medios de comunicación de la Facultad de Comunicación Social y Periodismo de la Universidad Nacional de La Plata. La Plata. Mayo de 2012, Buenos Aires, FLACSO-Ed. Homo Sapiens

FELDFEBER, Myriam. (2003). Estado y reforma educativa: la construcción de nuevos sentidos para la educación pública en la Argentina en el libro En Los sentidos de lo público. Reflexiones desde el campo educativo ¿Existe un espacio público no estatal?, Ediciones Novedades Educativas. Buenos Aires

FREIRE, Paulo y otros. (1987). Pedagogía, diálogo y conflicto, Buenos Aires, Ediciones Cinco

FREIRE, Paulo. (1970). Pedagogía del oprimido, Montevideo, Tierra Nueva

FREIRE, Paulo. (1991). La importancia de leer y el proceso de liberación, México, Siglo XXI Editores 
GAMARNIK, Cora Edith. (2009). Estereotipos sociales y medios de comunicación: un círculo vicioso, Questión; vol. 1, no. 23

GAUNA, Christian. (2014). "El lenguaje cinematográfico como dispositivo de intervención escolar y socioeducativo." Ponencia escrita para el Congreso Latinoamericano y del Caribe de Educación, Comunicación y Políticas Públicas en el territorio. Goya, Corrientes, Argentina, 30, 31 de octubre y 1 de noviembre de 2014

GAUNA, Christian. (2014). "Mediación del cine y su lenguaje como un dispositivo." Ponencia escrita para la I Bienal Latinoamericana de Infancias y Juventudes. Manizales, Caldas, Colombia, noviembre 17 al 21 de 2014

GIROUX, Henry. (2012). La educación y la crisis del valor de lo público. Desafiando la agresión a los docentes, los estudiantes y la educación pública de Montevideo, Criatura Editora

GRECO, Maria Beatriz. (2012). Emancipación, educación y autoridad. Prácticas de formación y transmisión democrática, Buenos Aires, Noveduc

GUBER, Rosana. (2001). La etnografía, Método, campo y reflexividad, Bogotá, Editorial Norma

HALL, Stuart. (1980). “Codificar y Decodificar" En: CULTURE, MEDIA Y LENGUAJE, London, Hutchinson, Pág. 129-139

HUERGO, Jorge. (1997). Comunicación y educación, ámbitos, prácticas y perspectivas, La Plata, Ediciones de Periodismo y Comunicación

HUERGO, Jorge. (2003). El reconocimiento del universo vocabular y la prealimentación de las acciones estratégicas. Recuperado de: http://www.unc.edu.ar/extensionunc/vinculacion/solidaridad/convocatoria-a-estudiantes-2012/segundo-taller-de-formacion2012/El\%20reconocimiento\%20del\%20201cuniverso\%20vocabular201d\%20y\%20la\%20prealim entacion\%20de\%20las\%20acciones\%20estrategicas\%20_\%20Por\%20Jorge\%20Huergo.pdf 
HUERGO, Jorge. (2007). Una primera aproximación al campo comunicación / educación, Recuperado de: http://comeduc.blogspot.com.ar/2007 $04 \quad 01$ archive.html

KAPLÚN, Mario. (1992). A la educación por la comunicación, Santiago de Chile, UNESCO/OREALC

LUNA, María del Rosario. (2012). Producción de narrativas audiovisuales: inclusión y desarrollo comunitario en sectores sociales desfavorecidos de la ciudad de Buenos Aires. En MARTíNEZ Hermida, M., MAYUGO i Majó, C. TAMARIT Rodríguez, A.(Coord), Comunidad y Comunicación, Prácticas comunicativas y medios comunitarios en Europa y América Latina. (pp. 205 - 216). Madrid, España, Editorial Fragua

MARRADI, Alberto, ARCHENTI, Nélida y PIOVANI, Juan Ignacio. (2007). Metodología de las ciencias sociales, Buenos Aires, Argentina, Emecé Editores

MATTELART, Armand y MATTELART, Michelle. (1997). Historia de las teorías de la comunicación. Paidós, Barcelona

Mc EWAN y EGAN. (1998). La narrativa en la enseñanza, el aprendizaje y la investigación. Buenos Aires, Amorrortu

ONETO, Fernando. (2011). La escuela tiene sentido. Convivir con extraños: la socialización en una cultura del disenso, Noveduc

RINCÓN, Omar. (2008). No más audiencias, todos devenimos productores. En Comunicar, 30, 93-98. http://dx.doi.org/10.3916/c30-2008-01-014

RINCÓN, Omar. (2011). Nuevas narrativas televisivas: relajar, entretener, contar, ciudadanizar, experimentar. En Comunicar, 36, 43-50. http://dx.doi.org/10.3916/C36-2011-02-04 
SAINTOUT, Florencia. (2009). "Los estudios Socioculturales y la Comunicación: un mapa desplazado". Ponencia presentada en ALAIC

SCHMUCLER, Héctor. (1986). "Comunicación, cultura y desarrollo". Ponencia presentada en la mesa de Comunicación y Desarrollo organizada por el IPAL en Lima.

SCHMUCLER, Héctor. (1984). "Un proyecto de comunicación / cultura". Revista de Comunicación y Cultura, México

SIBILIA, Paula. (2012). Redes o paredes. La escuela en tiempos de distinción de dispersión. Tinta Fresca

TIRAMONTI, Guillermina. (2011). Variaciones de la forma escolar. Límites y posibilidades de la escuela media.

TIRAMONTI, Guillermina, MONTES, Nancy. (2009). La escuela media en debate. Problemas actuales y perspectivas de la investigación, Editorial Manantial/Flacso

TRILLA, Jaume. (1997). La educación y la ciudad. Revista IDEP. No 2. Bogotá

VARGAS, Patricia. (2005). Bolivianos, paraguayos y argentinos en la obra. Identidades étniconacionales dentro los trabajadores de la construcción. Editorial Antropofagia

VILLA, Alicia, MARTÍNEZ, María. Elena. (2014). Relaciones escolares y diferencias culturales: la educación en perspectiva intercultural. Noveduc 


\section{ANEXOS}

Se anexa en soporte digital, el video que elaboré sobre mi participación en el programa CineZap. Este contiene: entrevistas de los participantes e imágenes sobre el proceso de creación de los cortometrajes en estas dos escuelas

A modo complementario se adjuntan los cortometrajes realizados en las dos escuelas y el video realizado por CineZap sobre el evento de proyección de los cortometrajes del 2015.

A continuación, se relacionan los links para acceder a este material de manera online:

- Video: El audiovisual como dispositivo de intervención. CineZap, Cine en las escuelas medias del sur de la ciudad de Buenos Aires.

Autor: Sandra Milena Sánchez

https://www.youtube.com/watch?v=ycg8b5sjSEE\&feature=youtu.be

- Cortometraje "Identidad Tomada" de la escuela Técnica Número 17 Brigadier General Don Cornelio de Saavedra (2015)

http://cinezap.com.ar/?p=2703

https://vimeo.com/146350002

- Cortometraje "Lazos" de la escuela de Educación Media No 6 Distrito Escolar 5 http://cinezap.com.ar/?p=5151 https://vimeo.com/193767465

- Video realizado por CineZap sobre la Muestra 2015:

https://vimeo.com/147534030 